INSTITUTO DE PESQUISAS ENERGÉTICAS E NUCLEARES Autarquia Associada à Universidade de São Paulo

\author{
ESTUDO E DESENVOLVIMENTO DE METODOLOGIA PARA \\ CONTROLE DE QUALIDADE EM PROCESSO DE PRODUÇÃO DE \\ FONTES SELADAS DE IODO-125 PARA APLICAÇÃO EM \\ BRAQUITERAPIA
}

JOÃO AUGUSTO MOURA

Dissertação apresentada como parte dos requisitos para obtenção do Grau de Mestre em Ciências na Área de Tecnologia Nuclear - Aplicações.

Orientadora:

Dra. Maria Elisa Chuery Martins Rostelato

São Paulo

2009 
Dedico este trabalho aos meus filhos e a todos que me incentivaram a realizá-lo. 


\section{Agradecimentos}

À Dra. Maria Elisa Chuery Martins Rostelato pela orientação, aconselhamento, valiosos comentários, confiança, paciência e amizade.

Ao Dr. José Eduardo Manzoli, pela generosa recepção no IPEN e valiosas conbtribuições.

Ao Dr. Carlos Zeituni, pelos valiosos comentários e amizade.

Ao Eduardo Moura, pelo companheirismo, participação e ajuda nos experimentos.

A MSc. Anselmo Feher, Vladimir Lepki, engenheiro Francisco Edmundo Sprenger e Cláudio Botelho pelas sugestões, comentários e ajuda nos experimentos.

A MSc. Pedro Eiti Aoki, Edmilson C. Amorim, Valdir Cosmos da Silva e MSc. Hélio Nagatomi, pela colaboração nas atividades de laboratório.

Aos profissionais do Centro de Tecnologia das Radiações pela amizade e colaboração durante a execução do trabalho.

Ao Dr.. Wilson A. P. Calvo, coordenador do Centro de Tecnologia das Radiações, pela infra-estrutura necessária à realização deste trabalho.

À Comissão de Pós Graduação e à Secretaria de Pós Graduação, pelo apoio e orientações.

À equipe de proteção radiológica pelo empenho na monitoração do laboratório.

Aos amigos da FATEC Sorocaba, pela amizade, apoio e incentivo.

A minha família, pelo apoio e incentivo durante as dificuldades.

A todos aqueles que, direta ou indiretamente contribuíram para a realização deste trabalho. 


\title{
ESTUDO E DESENVOLVIMENTO DE METODOLOGIA PARA CONTROLE DE QUALIDADE EM PROCESSO DE PRODUÇÃO DE FONTES SELADAS DE IODO-125 PARA APLICAÇÃO EM BRAQUITERAPIA
}

\author{
João Augusto Moura
}

\begin{abstract}
RESUMO
O câncer é hoje a segunda maior causa de morte por doenças em vários países, inclusive o Brasil. Excluindo-se o câncer de pele não melanoma, o câncer de próstata é o mais incidente na população, em geral. O tumor de próstata pode ser tratado por diversos métodos, incluindo a braquiterapia, que consiste na colocação de fontes radioativas seladas na forma de sementes, contendo o radioisótopo iodo-125 junto ao tumor. Dessa maneira, a região alvo do tratamento recebe alta dose de radiação, sendo essa dose reduzida sensivelmente nos tecidos circunvizinhos saudáveis. A semente é composta de uma cápsula de titânio selada por meio de soldagem, com 0,8mm de diâmetro externo e 4,5mm de comprimento, contendo em seu interior um fio de prata de $0,5 \mathrm{~mm}$ de diâmetro, com o iodo-125 adsorvido. Após sua construção, a semente deve ser submetida a um ensaio de estanqueidade, garantindo a ausência de qualquer vazamento de material radioativo. Os principais objetivos deste trabalho foram o estudo e desenvolvimento dos métodos de ensaio de estanqueidade aplicáveis às sementes de iodo-125, propostos pela norma ISO $9978^{20}$, a escolha do método mais adequado para o processo de produção e a determinação do fluxograma do processo a ser utilizado. Os ensaios realizados excederam a exigência da norma, com a aplicação de ultra-som durante o período de imersão das sementes. Os resultados mostraram a eficácia da aplicação de ultra-som, aumentando muito a detecção de vazamentos de material radioativo. Os melhores resultados foram obtidos utilizando-se água destilada a $20^{\circ} \mathrm{C}$ com imersão por 24 horas e água destilada a $70^{\circ} \mathrm{com}$ imersão por 30 minutos. Esses métodos são os escolhidos para serem utilizados durante a produção das sementes. O fluxograma de processo desenvolvido contempla todas as fases do ensaio de estanqueidade, de acordo com a seqüência realizada durante os experimentos.
\end{abstract}




\title{
STUDY AND METODOLOGY DEVELOPMENT FOR QUALITY CONTROL IN THE PRODUCTION PROCESS OF IODINE-125 RADIOACTIVE SEALED SOURCES APPLIED TO BRACHYTHERAPY
}

\author{
João Augusto Moura
}

\begin{abstract}
Today cancer is the second cause of death by disease in several countries, including Brazil. Excluding skin cancer, prostate cancer is the most incident in the population. Prostate tumor can be treated by several ways, including brachytherapy, which consists in introducing sealed radioactive sources (lodine 125 seeds) inside the tumor. The target region of treatment receives a high radiation dose, but healthy neighbor tissues receive a significantly reduced radiation dose. The seed is made of a welding sealed titanium capsule, $0.8 \mathrm{~mm}$ external diameter and $4.5 \mathrm{~mm}$ length, enclosing a $0.5 \mathrm{~mm}$ diameter silver wire with lodine-125 adsorbed. After welded, the seeds have to be submitted to a leak test to prevent any radioactive material release. The aims of this work were: (a) the study of the different leakage test methods applied to radioactive seeds and recommended by the ISO $9978^{20}$, (b) the choice of the appropriate method and (c) the flowchart determination of the process to be used during the seeds production. The essays exceeded the standards with the use of ultra-sound during immersion and the corresponding benefits to leakage detection. Best results were obtained with the immersion in distilled water at $20^{\circ} \mathrm{C}$ for 24 hours and distilled water at $70^{\circ} \mathrm{C}$ for 30 minutes. These methods will be used during seed production. The process flowchart has all the phases of the leakage tests according to the sequence determined in the experiments.
\end{abstract}




\section{SUMÁRIO}

Página

1 INTRODUÇÃO.

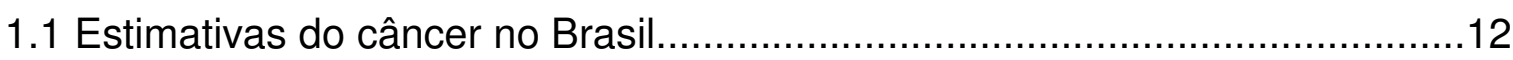

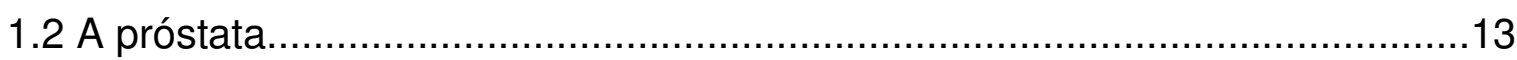

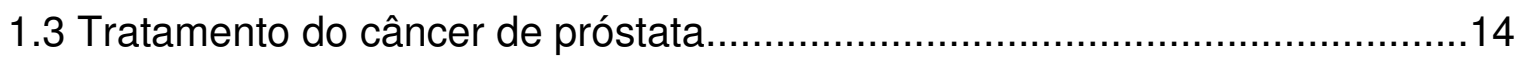

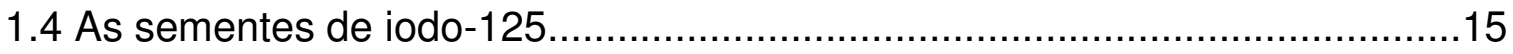

1.5 Fontes radioativas seladas: requisitos gerais e classificação.........................17

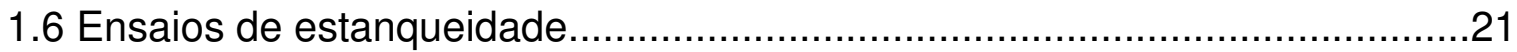

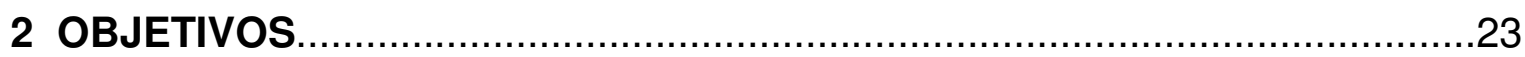

3 REVISÃO DA LITERATURA

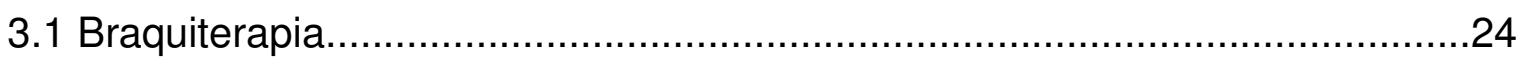

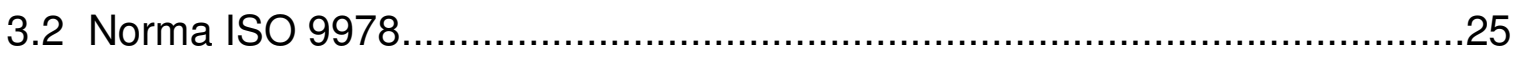

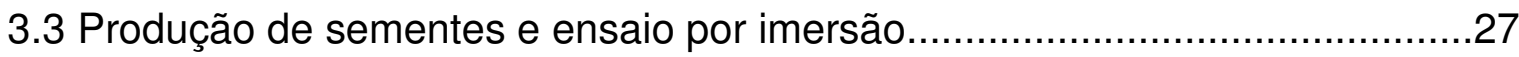

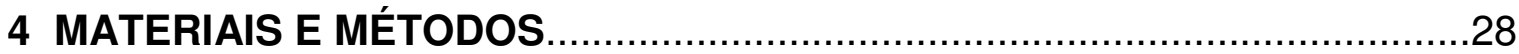

4.1 Determinação de layout do processo de controle de qualidade.......................28

4.2 Construção de dispositivos para os ensaios de estanqueidade......................29

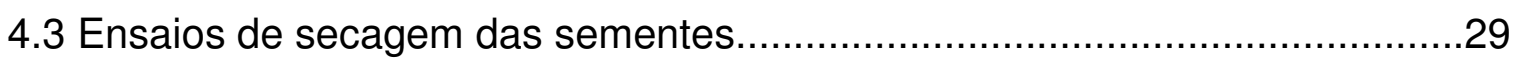

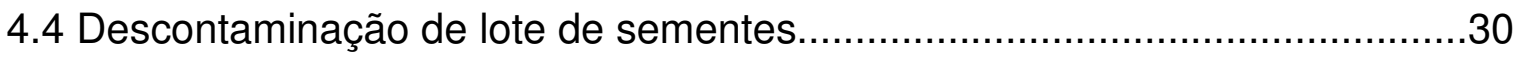

4.5 Descontaminação da tubulação de transferência de líquidos .........................31

4.6 Influência da variação de parâmetros nos métodos recomendados.................34

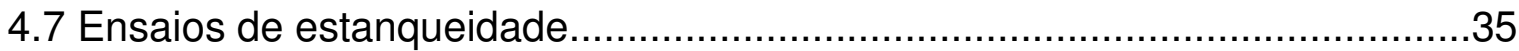

4.8 Correção dos resultados devido ao decaimento..........................................38

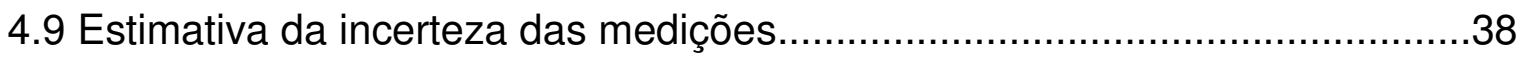

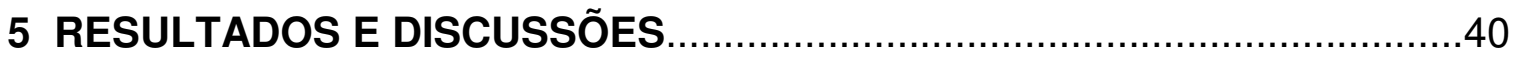

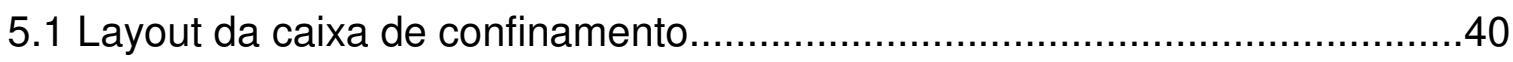

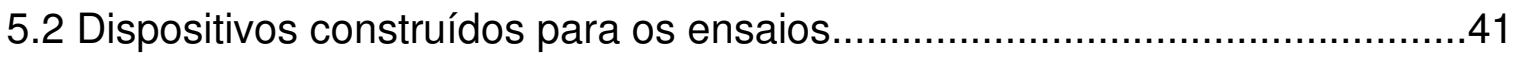

5.3 Resultados dos ensaios de secagem das sementes...................................4 
5.4 Resultados do ensaio de descontaminação de lote de sementes .44

5.5 Resultados dos ensaios de transferência de líquidos e descontaminação da tubulação. 47

5.6 Resultados da variação de parâmetros nos métodos recomendados.............53

5.7 Resultados das medidas de atividade das sementes...................................55

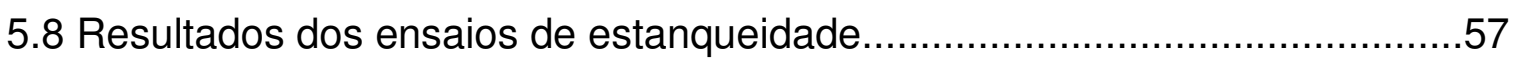

5.9 Fluxograma de processo do ensaio de estanqueidade................................62

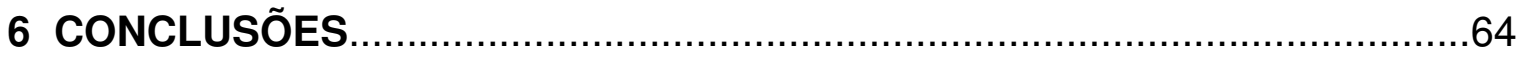

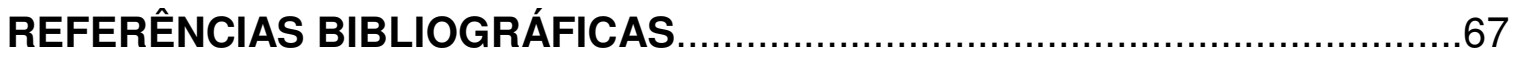




\section{LISTA DE TABELAS}

Página

TABELA 1 - Nível de atividade especificada de acordo com o grupo do radionuclídeo

TABELA 2 - Classificação de desempenho de fontes seladas (5 dígitos). 19

TABELA 3 - Classificação para fontes seladas utilizadas em aplicações médicas. 20

TABELA 4 - Seleção do método de teste de estanqueidade. 21

TABELA 5 - Variações ensaiadas nos métodos por imersão 34

TABELA 6 - Resultados de secagem obtidos com bomba de vácuo. 44

TABELA 7 - Resultados de secagem obtidos com aspirador de pó. .44

TABELA 8 - Resultados da descontaminação de lote de sementes utilizando água destilada e ultra-som.

TABELA 9 - Resultados da descontaminação de lote de semente utilizando água destilada com detergente e aplicação de ultra-som.

TABELA 10 - Resultados da descontaminação de lote de sementes após meia vida do iodo -131 utilizando água destilada e aplicação de ultra-som

TABELA 11 - Resultados do ensaio ํㅜ 1 - descontaminação de mangueira de silicone.

TABELA 12 - Resultados do ensaio n2- - descontaminação de mangueira de silicone.

TABELA 13 - Resultados do ensaio 꾼 - descontaminação de mangueira de silicone.

TABELA 14 - Resultados do ensaio no4-descontaminação de mangueira de silicone.

TABELA 15 - Resultados do ensaio № 5 - descontaminação de mangueira de PTFE.

TABELA 16 - Resultados obtidos com as variações nos ensaios de 
estanqueidade.

.54

TABELA 17 - Valores de atividade das sementes.

TABELA 18 - Resultados dos ensaios de estanqueidade utilizando líquido cintilador.

TABELA 19 - Resultados dos ensaios de estanqueidade em temperatura ambiente.

TABELA 20 - Resultados dos ensaios de estanqueidade à temperatura de $50^{\circ} \mathrm{C}$

TABELA 21 - Resultados dos ensaios de estanqueidade à temperatura de $70^{\circ} \mathrm{C}$

TABELA 22 - Resultados dos ensaios de estanqueidade com fervura. 60

TABELA 23 - Valor médio e mínimo de atividade para cada método ensaiado. 


\section{LISTA DE FIGURAS}

Página

FIGURA 1 - Tipos de câncer mais incidentes. Estimativa para $2008^{4}$ .13

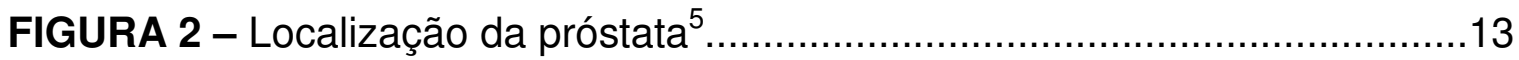

FIGURA 3 - Vista em corte da próstata com suas várias glândulas ${ }^{6}$....................14

FIGURA 4 - Imagem de um implante de sementes de iodo- $125^{11} \ldots \ldots \ldots \ldots \ldots \ldots \ldots . . .15$

FIGURA 5 - Diagrama esquemático de decaimento do iodo- $125^{14} \ldots \ldots \ldots \ldots \ldots \ldots . . . .16$

FIGURA 6 - Desenho esquemático da semente a ser produzida pelo IPEN ${ }^{12} \ldots .17$

FIGURA 7 - Exemplo de codificação de fonte selada para braquiterapia.............20

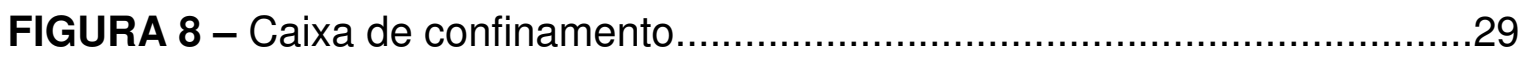

FIGURA 9 - Sistema de transferência com bomba peristáltica...........................32

FIGURA 10 - Sistema de transferência através de bomba de vácuo....................33

FIGURA 11- Sistema de corte (a) e operação de corte (b).................................36

FIGURA 12- Desenho esquemático da disposição dos equipamentos no interior da caixa de confinamento................................................40

FIGURA 13 - Suporte para rolhas cônicas de borracha.....................................41

FIGURA 14 - Desenho do suporte para tubos (a) e sua utilização (b)................42

FIGURA 15 - Desenho esquemático do dispositivo para secagem das sementes

FIGURA 16 - Representação do conjunto de secagem (a) e detalhe do tubo com tela de retenção (b)

FIGURA 17 - Tela de retenção (a) e sua montagem (b)

FIGURA 18 - Resultados da descontaminação de lote de sementes utilizando água destilada e ultra-som.

FIGURA 19 - Resultados da descontaminação de lote de sementes utilizando água destilada com detergente e ultra-som

FIGURA 20 - Resultados da descontaminação de lote de sementes decorrida uma meia vida do iodo -131utilizando água destilada e aplicação de ultra-som.

FIGURA 21 - Resultados do ensaio no 1 - descontaminação de mangueira de silicone.

FIGURA 22 - Resultados do ensaio no 2 - descontaminação de 
mangueira de silicone

49

FIGURA 23 - Resultados do ensaio nํㅜ 3 - descontaminação de mangueira de silicone.

FIGURA 24 - Resultados do ensaio no 4 - descontaminação de mangueira de silicone. .51

FIGURA 25 - Resultados do ensaio nํ5 - descontaminação de Mangueira de PTFE .53

FIGURA 26 - Semente de iodo-125 cortada com alicate. .54

FIGURA 27 - Imagens de três sementes submetidas ao corte. .56

FIGURA 28 - Imagens das sementes $n^{\circ} 47$ (a) e $n^{\circ} 60$ (b) .59

FIGURA 29 - Valores médios de atividade para cada método utilizado. 61

FIGURA 30 - Valores mínimos de atividade para cada método utilizado. 62

FIGURA 31 - Fluxograma de processo dos ensaios de estanqueidade........ .63 


\section{INTRODUÇÃO}

O nome câncer é dado a um conjunto de mais de cem doenças que tem em comum o crescimento desordenado e invasivo de células, em várias partes do organismo ${ }^{1}$.

A doença é definida por características que descrevem a diferença de comportamento das células cancerosas em relação às normais. A clonalidade é o resultado de alterações genéticas em uma célula, que provocam sua proliferação, formando um clone de células malignas. A autonomia é o crescimento não adequadamente regulado pelas influências bioquímicas e físicas normais do ambiente. A anaplasia é ausência de diferenciação normal e coordenada das células. A metástase resulta da capacidade das células cancerosas de crescimento descontínuo e disseminação para outras partes do corpo ${ }^{2}$.

O diagnóstico de câncer é estabelecido por meio do exame histopatológico. Além de excluir outros processos, como por exemplo, os inflamatórios e os tumores benignos, esse exame proporciona o conhecimento do tecido de origem do processo maligno, necessário para a seleção da terapia apropriada ${ }^{2}$.

\subsection{Estimativas do câncer no Brasil}

$\mathrm{Na}$ maioria dos países o câncer é a segunda causa de mortes por doenças, subseqüente às doenças cardiovasculares ${ }^{3}$. As estimativas para o ano de 2008 e 2009 indicam a ocorrência de 466.730 novos casos de câncer no Brasil, sendo 231.860 para o sexo masculino e 234.870 para o sexo feminino. Os tumores mais incidentes para o sexo masculino serão respectivamente o câncer de pele não melanoma (56 mil casos) e o câncer de próstata (49 mil casos). $\mathrm{Na}$ população em geral, o câncer de pele não melanoma será o primeiro mais incidente nos anos de 2008 e 2009, seguido pelo câncer de próstata e o câncer de mama feminina (FIG. 1$)^{4}$. 


\section{No de Casos}

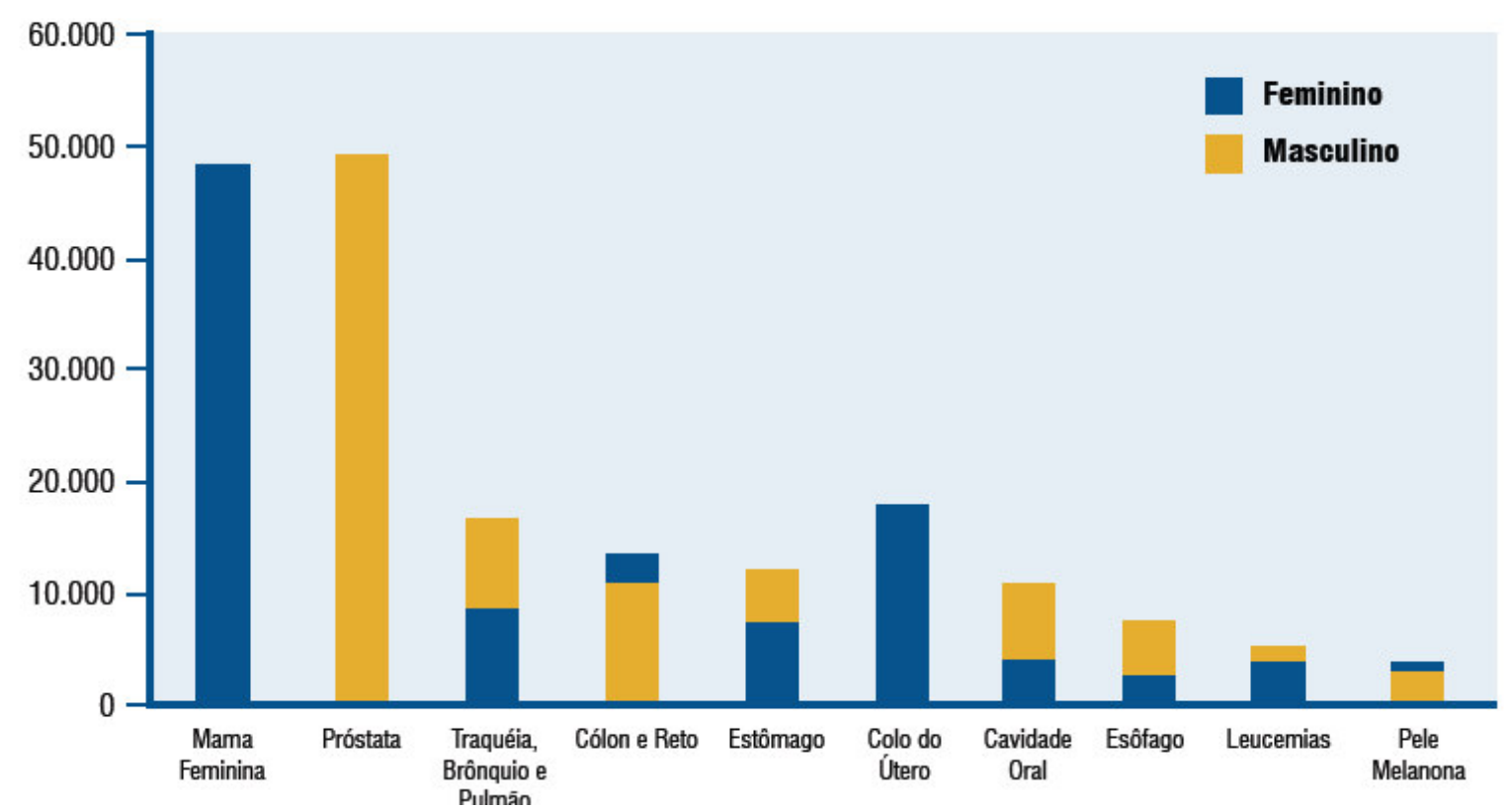

FIGURA 1: Tipos de câncer mais incidentes. Estimativa para 2008. Fonte: Instituto Nacional de Câncer (INCA) .

\subsection{A próstata}

A próstata é um órgão que abraça a uretra logo abaixo da bexiga urinária (FIG. 2) ${ }^{5}$. É composta por pequenas glândulas tubulo-alveolares, cujos ductos desembocam na uretra. As pequenas estruturas prostáticas são divididas em glândulas da mucosa, da submucosa e principais (FIG. 3$)^{6}$.

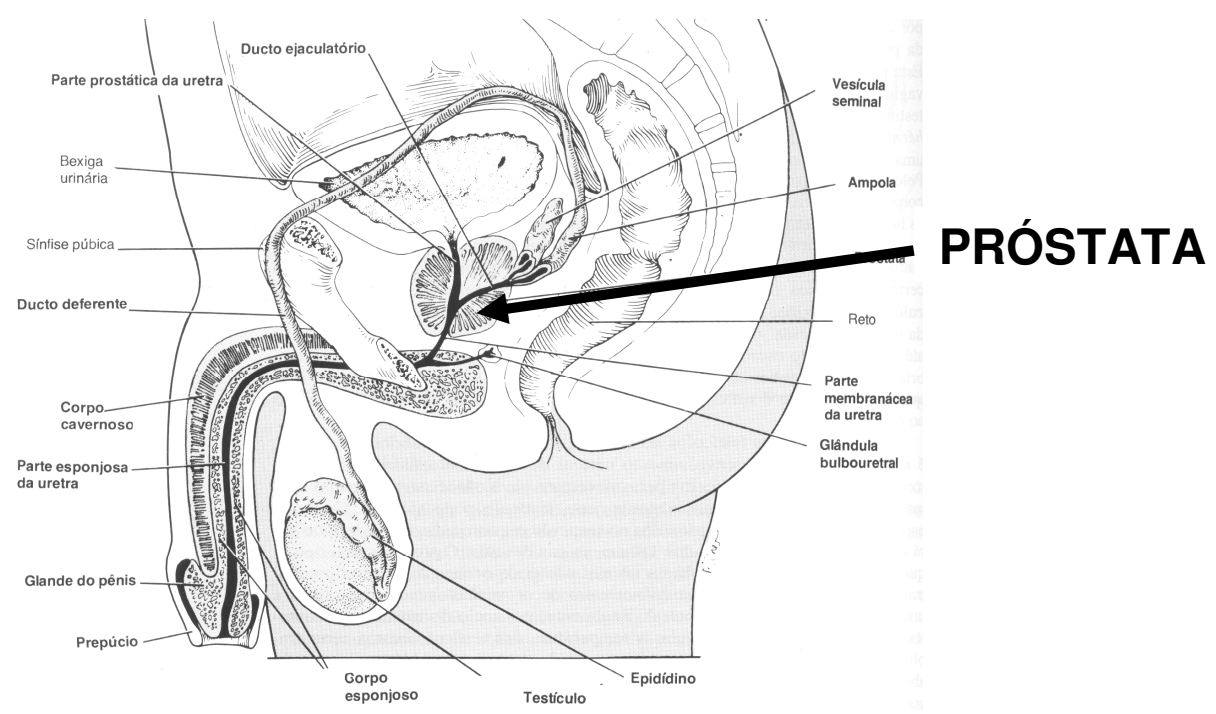

FIGURA 2: Localização da próstata 5 . 


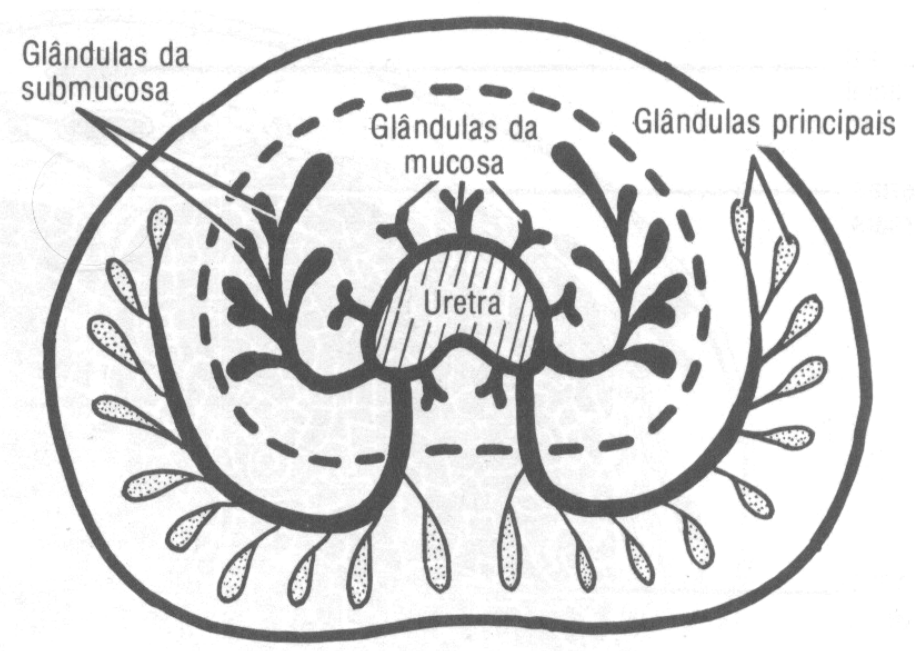

FIGURA 3: Vista em corte da próstata mostrando as glândulas da mucosa, da submucosa e principais ${ }^{6}$.

Por motivos não totalmente esclarecidos, frequentemente após certa idade, as glândulas mucosas e submucosas crescem muito, ocasionando o quadro denominado hiperplasia prostática ${ }^{1,6}$. Esse distúrbio benigno afeta $80 \%$ a 90\% dos homens acima de 40 anos de idade, estrangulando a luz uretral e criando variados graus de dificuldade para urinar ${ }^{7}$. Na oitava década de vida, mais de $90 \%$ dos homens apresentam hiperplasia prostática na necropsia ${ }^{1}$. Outro distúrbio que afeta a próstata, este de caráter maligno, é o câncer de próstata, considerado um câncer da terceira idade uma vez que cerca de $75 \%$ dos casos no mundo ocorrem a partir dos 65 anos de idade ${ }^{8}$.

\subsection{Tratamento do câncer de próstata}

O câncer de próstata pode ser tratado por cirurgia ou por radioterapia, dependendo do estágio e agressividade da doença, bem como de fatores individuais do paciente. A cirurgia realizada é a prostatectomia radical, que retira a próstata e tecidos vizinhos. Os principais efeitos colaterais são a incontinência urinária e a impotência sexual ${ }^{9}$. 
O tratamento por radioterapia pode ser de dois tipos. Na teleterapia, feita com feixe de radiação externo, o órgão bem como os tecidos da região vizinha recebem um feixe de radiação proveniente de um acelerador de elétrons. O outro tipo de radioterapia é denominado braquiterapia e consiste na colocação de fontes radioativas junto ao tumor. Dessa maneira, a região alvo do tratamento recebe alta dose de radiação, sendo essa dose reduzida sensivelmente nos tecidos vizinhos saudáveis ${ }^{10}$. A braquiterapia pode ser realizada com sementes de iodo-125 ou fontes de irídio-192 de alta taxa de dose (HDR). O implante de sementes de iodo-125 na próstata é permanente. A FIG. 4 mostra uma representação de um implante na próstata de sementes de iodo- $125^{11}$.

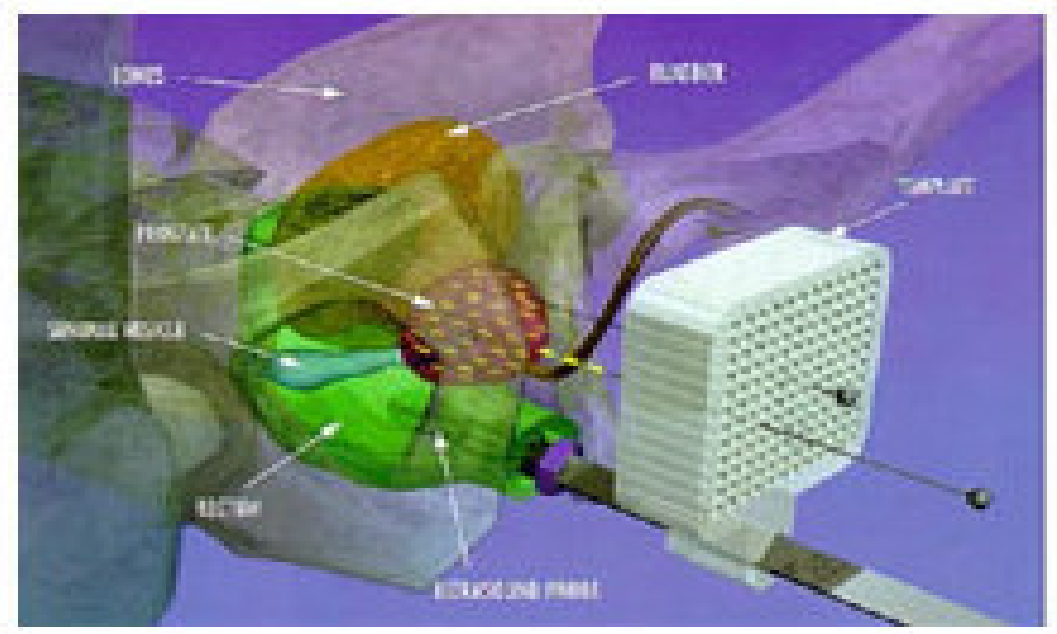

FIGURA 4: Representação de um implante de sementes de iodo- $125^{11}$.

\subsection{As sementes de iodo-125}

O uso de sementes de iodo-125 no tratamento do câncer de próstata vem acontecendo no Brasil, em hospitais e clínicas particulares, sendo que cada implante utiliza no mínimo 80 sementes. Uma vez que não existem fabricantes no Brasil, as sementes utilizadas são importadas a custos elevados (US\$34,00 por unidade), onerando o tratamento e dificultando sua disponibilização para hospitais da rede pública. Para diminuir esse custo e viabilizar a implantação do tratamento no sistema público de saúde, foi feito um estudo e desenvolvida uma nova tecnologia de fabricação de sementes de iodo-125, pelo Instituto de Pesquisas Energéticas e Nucleares (IPEN). Devido à sua originalidade, essa tecnologia dispensa o pagamento de royalties aos fabricantes estrangeiros, além de diminuir o custo de produção. A demanda nacional, estimada por representantes da classe 
médica brasileira, é de 8000 sementes $/ \mathrm{mês}^{12}$. Atualmente encontra-se em fase de implantação o laboratório para produção das sementes de iodo-125, no Centro de Tecnologia das Radiações do IPEN.

O iodo-125 é produzido em reator nuclear a partir do xenônio- $124^{13}$. Decai por captura eletrônica e conversão interna para o telúrio-125 (FIG. 5) ${ }^{14}$. No processo, emite fótons de $27 \mathrm{keV}, 31 \mathrm{keV}$ e $35 \mathrm{keV}$, com energia média de $29 \mathrm{keV}$. Em virtude da baixa energia média de emissão, seus fótons têm pouco poder de penetração, ou seja, caminham pouco no tecido e são absorvidos permitindo a aplicação de altas doses de radiação na próstata sem atingir os órgãos próximos. O isótopo possui uma meia-vida de 59,4 dias $^{15}$.

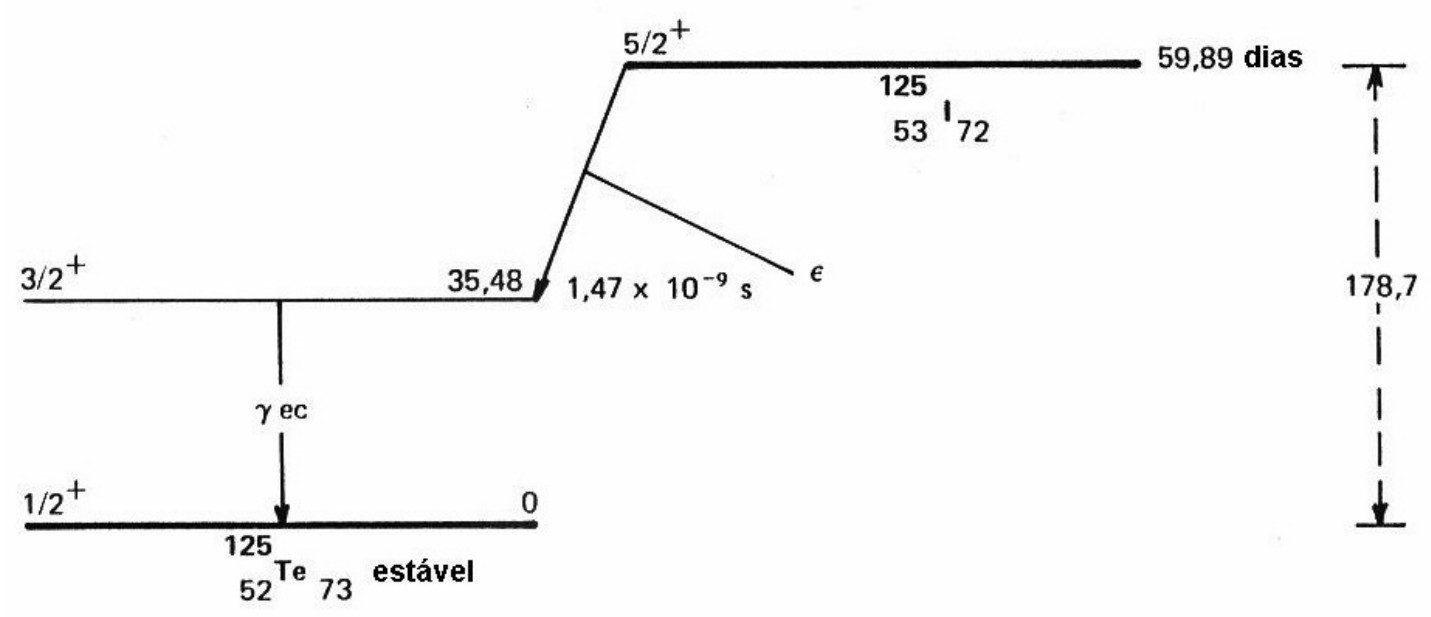

FIGURA 5: Diagrama esquemático de decaimento do iodo- $125^{14}$.

As sementes a serem produzidas pelo IPEN empregam como invólucro um tubo de titânio de $4,5 \mathrm{~mm}$ de comprimento, $0,8 \mathrm{~mm}$ de diâmetro externo e parede de $0,05 \mathrm{~mm}$. No interior do tubo é introduzido um fio de prata com $0,5 \mathrm{~mm}$ de diâmetro e 3mm de comprimento, contendo o iodo-125 adsorvido. A escolha do titânio se deve à sua biocompatibilidade. As dimensões da cápsula e as demais características dessa semente coincidem com as do modelo mais utilizado atualmente no Brasil, facilitando sua introdução e aceitação no mercado nacional. A FIG. 6 mostra o desenho esquemático da semente de iodo-125 a ser produzida pelo IPEN ${ }^{12}$. 


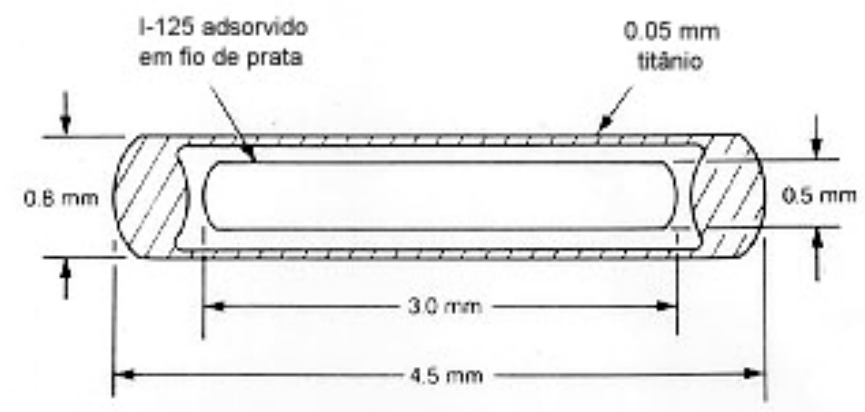

FIGURA 6: Desenho esquemático da semente a ser produzida pelo IPEN ${ }^{12}$.

A etapa final da construção das sementes é a soldagem do tubo de titânio, que será realizada com sistema de soldagem a laser. Essa operação enclausura o radioisótopo e seu substrato, isolando-os do meio externo. Devido a essa característica, as sementes são classificadas como fontes radioativas seladas $^{16}$. O invólucro possibilita a passagem da radiação, porém deve garantir a ausência de vazamento do radioisótopo contido. Essa condição será verificada ao final do processo de fabricação, por meio de testes de estanqueidade ${ }^{17,18,19}$. Esses ensaios devem ser realizados conforme orienta a norma International Standard Organization. Radiation protection - leakage test metods ISO $9978^{20}$.

\subsection{Fontes radioativas seladas: requisitos gerais e classificação}

A produção de fontes radioativas seladas requer o estabelecimento de critérios para o desenvolvimento e fabricação, garantindo sua conformidade com as exigências de proteção radiológica.

Durante o desenvolvimento do produto é necessário fazer sua classificação e a verificação do seu desempenho em relação a segurança. Para isso se utiliza a norma International Standard Organization. Radiation protection Sealed radioactive sources - General requirements and classification- ISO $2919^{21}$. Essa norma orienta que seja feita a classificação do produto analisando-se inicialmente a toxicidade do radioisótopo utilizado e enquadrando-o em um dos quatro grupos: muito alta, alta, moderada ou baixa toxicidade (A, B1, B2, C), conforme tabela contida no anexo $A$ da mesma norma. $O$ iodo-125 é classificado pela norma no grupo B1, alta toxicidade. 
Em seguida, devem ser analisadas a atividade da fonte a ser produzida e a característica de lixiviação do material radioativo utilizado, em relação à toxicidade determinada na etapa anterior. O resultado dessa comparação será designado por uma letra maiúscula. A letra " $\mathrm{C}$ " indica que a atividade da fonte não excede os limites especificados. A letra "E" indica que a atividade da fonte excede os valores especificados. Os valores de referência para essa comparação se encontram na TAB. $1^{21}$. Essa tabela especifica valores de atividade, acima dos quais as fontes serão submetidas a ensaios diferenciados, incluindo fogo e explosão.

TABELA $1^{21}$ : Atividade especificada de acordo com o grupo do radionuclídeo.

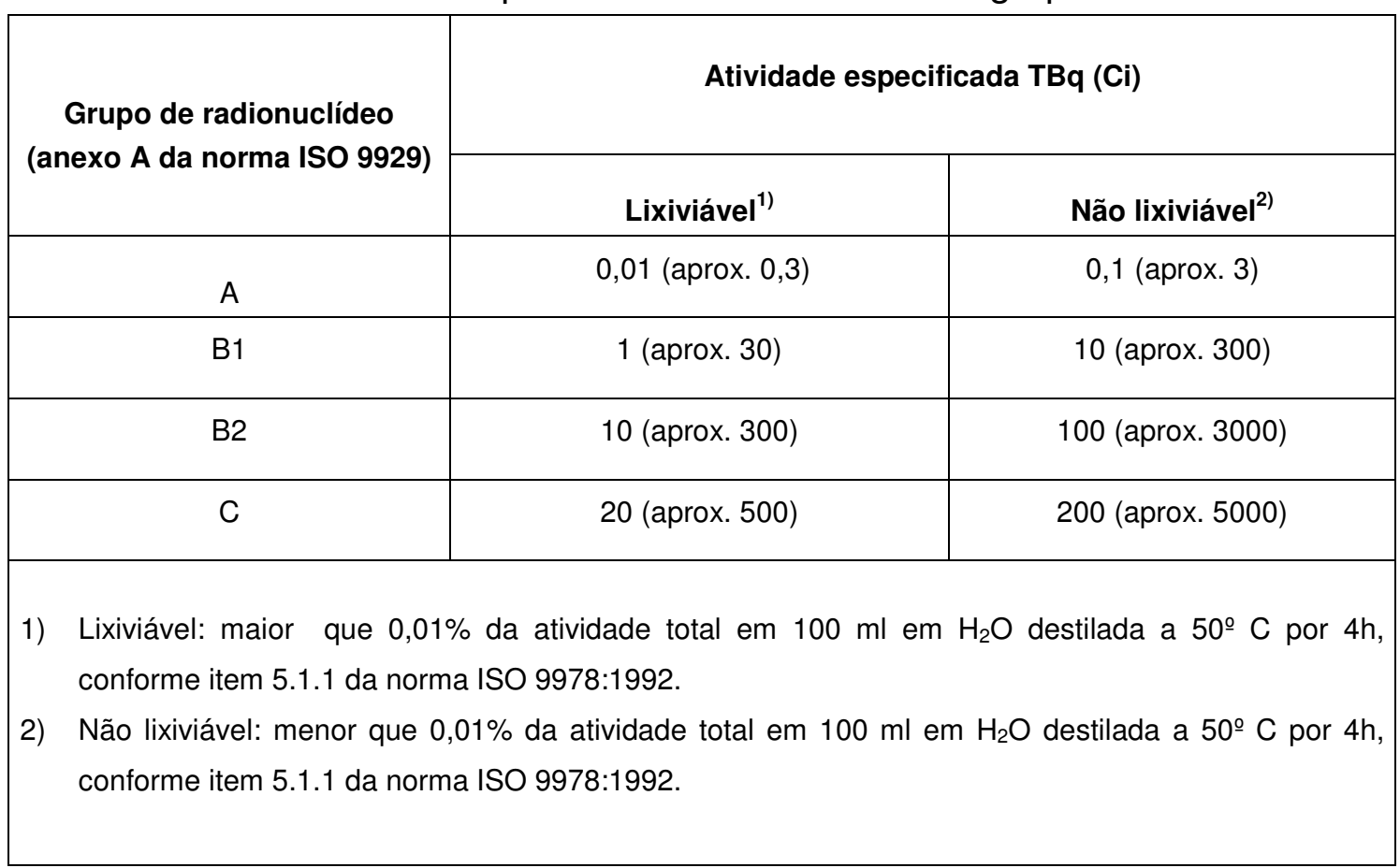

Na seqüência devem ser realizados ensaios para determinar o nível de desempenho do produto com relação aos requisitos de segurança. Esses ensaios consistem basicamente na exposição do produto a temperatura, pressão externa, impacto, vibração e puncionamento, sendo previstos vários níveis de severidade para cada tipo de ensaio. A TAB. $2^{21}$ mostra a classificação do desempenho de fontes seladas, de acordo com a severidade dos cinco ensaios recomendados. 
TABELA $2^{21}$ : Classificação de desempenho de fontes seladas (5 dígitos).

\begin{tabular}{|c|c|c|c|c|c|c|c|}
\hline \multirow{2}{*}{ Ensaio } & \multicolumn{7}{|c|}{ Classe } \\
\hline & 1 & 2 & 3 & 4 & 5 & 6 & $\mathbf{X}$ \\
\hline $\begin{array}{l}\text { Tempe } \\
\text { ratura }\end{array}$ & $\begin{array}{c}\text { Não } \\
\text { testado }\end{array}$ & $\begin{array}{l}-40^{\circ} \mathrm{C} \\
(20 \mathrm{~min} .) \\
+80^{\circ} \mathrm{C} \\
(1 \mathrm{~h})\end{array}$ & $\begin{array}{l}-40^{\circ} \mathrm{C}(20 \mathrm{~min} .) \\
+180^{\circ} \mathrm{C}(1 \mathrm{~h})\end{array}$ & $\begin{array}{l}-40^{\circ} \mathrm{C}(20 \\
\text { min. }) \\
+400^{\circ} \mathrm{C}(1 \mathrm{~h}) \\
\text { e choque } \\
\text { térmico } \\
\text { para } 20^{\circ} \mathrm{C}\end{array}$ & $\begin{array}{c}-40^{\circ} \mathrm{C}(20 \mathrm{~min} .) \\
+600^{\circ} \mathrm{C}(1 \mathrm{~h}) \\
\text { e choque térmico } \\
\text { para } 20^{\circ} \mathrm{C}\end{array}$ & $\begin{array}{c}-40^{\circ} \mathrm{C}(20 \\
\text { min.) } \\
+800^{\circ} \mathrm{C}(1 \mathrm{~h}) \\
\text { e choque } \\
\text { térmico } \\
\text { para } 20^{\circ} \mathrm{C}\end{array}$ & $\begin{array}{c}\text { Teste } \\
\text { especial }\end{array}$ \\
\hline $\begin{array}{l}\text { Pressão } \\
\text { Externa }\end{array}$ & $\begin{array}{c}\text { Não } \\
\text { testado }\end{array}$ & $\begin{array}{c}25 \mathrm{kPa} \\
\text { absoluto } \\
\text { para } \\
\text { atmosféri } \\
\text { ca } \\
\end{array}$ & $\begin{array}{c}25 \mathrm{kPa} \text { absoluto } \\
\text { para } 2 \mathrm{MPa} \\
\text { absoluto }\end{array}$ & $\begin{array}{c}25 \mathrm{kPa} \\
\text { absoluto para } \\
7 \mathrm{MPa} \\
\text { absoluto }\end{array}$ & $\begin{array}{c}25 \mathrm{kPa} \text { absoluto } \\
\text { para } 70 \mathrm{MPa} \\
\text { absoluto }\end{array}$ & $\begin{array}{c}25 \mathrm{kPa} \\
\text { absoluto para } \\
170 \mathrm{MPa} \\
\text { absoluto }\end{array}$ & $\begin{array}{c}\text { Teste } \\
\text { especial }\end{array}$ \\
\hline Impacto & $\begin{array}{c}\text { Não } \\
\text { testado }\end{array}$ & $\begin{array}{c}50 \mathrm{~g} \text { de } 1 \\
\text { metro ou } \\
\text { energia } \\
\text { de } \\
\text { impacto } \\
\text { equivalen } \\
\text { te }\end{array}$ & $\begin{array}{l}200 \mathrm{~g} \text { de } 1 \text { metro } \\
\text { ou energia de } \\
\text { impacto } \\
\text { equivalente }\end{array}$ & $\begin{array}{c}2 \mathrm{~kg} \text { de } 1 \\
\text { metro ou } \\
\text { energia de } \\
\text { impacto } \\
\text { equivalente }\end{array}$ & $\begin{array}{l}5 \mathrm{~kg} \text { de } 1 \text { metro } \\
\text { ou energia de } \\
\text { impacto } \\
\text { equivalente }\end{array}$ & $\begin{array}{c}20 \mathrm{~kg} \text { de } 1 \\
\text { metro ou } \\
\text { energia de } \\
\text { impacto } \\
\text { equivalente }\end{array}$ & $\begin{array}{c}\text { Teste } \\
\text { Especial }\end{array}$ \\
\hline $\begin{array}{l}\text { Vibra } \\
\text { ção }\end{array}$ & $\begin{array}{l}\text { Não } \\
\text { testado }\end{array}$ & $\begin{array}{c}3 \text { vezes } \\
10 \mathrm{~min} . \\
25 \text { a } 500 \\
\mathrm{~Hz} \mathrm{e} \\
49 \mathrm{~m} / \mathrm{s}^{2} \\
\left(5 \mathrm{~g}_{\mathrm{n}}\right)^{1)}\end{array}$ & $\begin{array}{c}3 \text { vezes } 10 \mathrm{~min} \text {. } \\
25 \text { a } 500 \mathrm{~Hz} \text { e } \\
49 \mathrm{~m} / \mathrm{s}^{2}\left(5 \mathrm{~g}_{\mathrm{n}}\right)^{1)} \\
\text { e } 50 \text { a } 90 \mathrm{~Hz} \\
\text { com } \\
\text { amplitude pico a } \\
\text { pico de } 0,635 \\
\mathrm{~mm} \\
\text { e } 90 \text { a } 500 \mathrm{~Hz} \\
\text { com } 98 \mathrm{~m} / \mathrm{s}^{2} \\
\left(10 \mathrm{~g}_{\mathrm{n}}\right)^{1)}\end{array}$ & $\begin{array}{c}3 \text { vezes } 30 \\
\text { min. } \\
25 \text { a } 80 \mathrm{~Hz} \\
\text { com } \\
\text { amplitude pico } \\
\text { a pico de } 1,5 \\
\mathrm{~mm} \\
\text { e } 80 \text { a } 2000 \\
\mathrm{~Hz} \mathrm{com} 196 \\
\mathrm{~m} / \mathrm{s}^{2}\left(20 \mathrm{~g}_{\mathrm{n}}\right)^{1)}\end{array}$ & Não utilizado & Não utilizado & $\begin{array}{c}\text { Teste } \\
\text { Especial }\end{array}$ \\
\hline $\begin{array}{c}\text { Puncio } \\
\text { na } \\
\text { mento }\end{array}$ & $\begin{array}{c}\text { Não } \\
\text { testado }\end{array}$ & $\begin{array}{c}1 \mathrm{~g} \text { de } 1 \\
\text { metro ou } \\
\text { energia } \\
\text { de } \\
\text { impacto } \\
\text { equivalen } \\
\text { te }\end{array}$ & $\begin{array}{l}10 \mathrm{~g} \text { de } 1 \text { metro } \\
\text { ou energia de } \\
\text { impacto } \\
\text { equivalente }\end{array}$ & $\begin{array}{c}50 \mathrm{~g} \text { de } 1 \\
\text { metro ou } \\
\text { energia de } \\
\text { impacto } \\
\text { equivalente }\end{array}$ & $\begin{array}{c}300 \mathrm{~g} \text { de } 1 \text { metro } \\
\text { ou energia de } \\
\text { impacto } \\
\text { equivalente }\end{array}$ & $\begin{array}{c}1 \mathrm{~kg} \text { de } 1 \\
\text { metro ou } \\
\text { energia de } \\
\text { impacto } \\
\text { equivalente }\end{array}$ & $\begin{array}{c}\text { Teste } \\
\text { Especial }\end{array}$ \\
\hline
\end{tabular}

A aprovação em qualquer dos ensaios será determinada pela capacidade da fonte selada em manter sua estanqueidade ao final do mesmo. Após cada ensaio a fonte deverá ser examinada visualmente para constatar sua integridade e deverá também ser submetida a um ensaio de estanqueidade, realizado de acordo com a norma ISO $9978^{20}$.

A norma ISO $2919^{21}$ também fornece uma lista com a classificação mínima de desempenho das fontes seladas, exigida para algumas aplicações típicas. A TAB. 3 foi extraída desta norma e mostra as exigências para fontes utilizadas em aplicações médicas. 
TABELA $3^{21}$ : classificação para fontes seladas utilizadas em aplicações médicas.

\begin{tabular}{|c|c|c|c|c|c|c|}
\hline \multirow{2}{*}{\multicolumn{2}{|c|}{$\begin{array}{l}\text { Aplicação da } \\
\text { fonte selada }\end{array}$}} & \multicolumn{5}{|c|}{ Classe da fonte selada } \\
\hline & & $\begin{array}{c}\text { Tempera- } \\
\text { Tura }\end{array}$ & Pressão & Impacto & Vibração & $\begin{array}{l}\text { Punciona- } \\
\text { Mento }\end{array}$ \\
\hline \multirow{4}{*}{ Médica } & Radiografia & 3 & 2 & 3 & 1 & 2 \\
\hline & $\begin{array}{c}\text { Gama } \\
\text { teleterapia }\end{array}$ & 5 & 3 & 5 & 2 & 4 \\
\hline & Braquiterapia & 5 & 3 & 2 & 1 & 1 \\
\hline & Aplicadores de superfície & 4 & 3 & 3 & 1 & 2 \\
\hline
\end{tabular}

Cada um dos ensaios (temperatura, pressão, impacto, vibração e puncionamento) corresponde a um determinado dígito no código de classificação do produto, podendo assumir diferentes valores (1 a 6), de acordo com o nível de desempenho requerido. $O$ resultado da classificação será um código alfanumérico que caracteriza o produto segundo a norma ISO 2919. A FIG. 7 mostra um exemplo de classificação de fonte selada para braquiterapia.

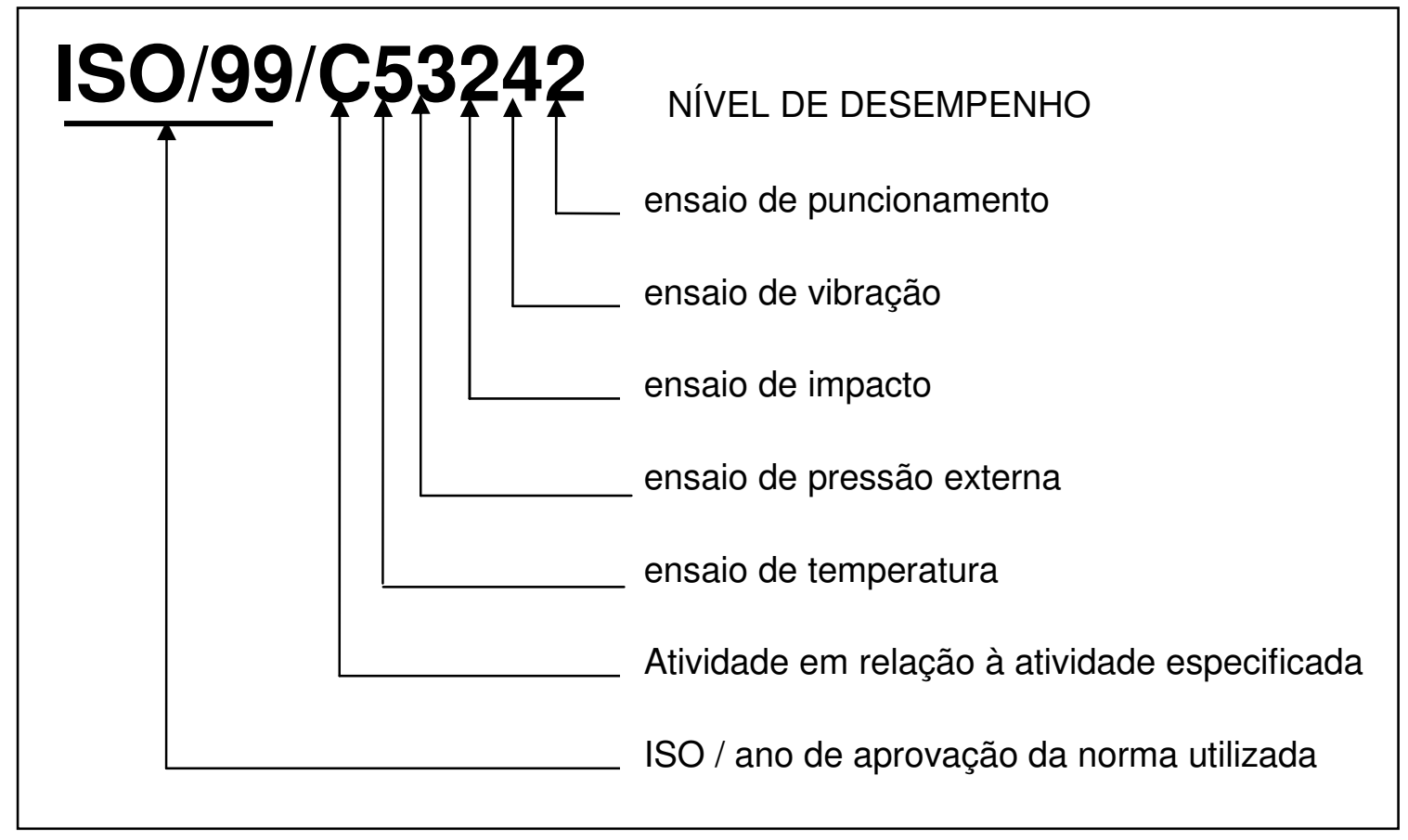

FIGURA 7: Exemplo de codificação de fonte selada para braquiterapia.

A norma ISO 2919 também orienta que na etapa de fabricação todas as fontes seladas deverão ser ensaiadas para garantir ausência de contaminação 
superficial e vazamento de material radioativo. Esses ensaios devem ser realizados com base na norma ISO $9978^{20}$. Além disso, todas as fontes fabricadas deverão ser medidas para determinar sua atividade.

\subsection{Ensaios de estanqueidade}

A norma ISO $9978^{20}$ estabelece as condições e procedimentos para execução dos ensaios de estanqueidade em fontes radioativas seladas, apresentando vários métodos para inspeção dessas fontes. Em seu anexo A, apresenta um guia para a escolha do método de ensaio a ser aplicado, dependendo do tipo de fonte a ser controlada (TAB. 4$)^{20}$.

TABELA $4^{20}$ : Seleção do método de ensaio de estanqueidade.

\begin{tabular}{|c|c|c|c|c|c|}
\hline \multirow{2}{*}{\multicolumn{2}{|c|}{ Tipo de fonte }} & \multicolumn{2}{|c|}{$\begin{array}{l}\text { Testes para produção de } \\
\text { fontes }\end{array}$} & \multicolumn{2}{|c|}{$\begin{array}{l}\text { Testes para classificação de } \\
\text { fontes }\end{array}$} \\
\hline & & Preferido & 2ª op̧ão & Preferido & 2a opção \\
\hline$A$ & $\begin{array}{c}\text { Fontes seladas contendo } \\
\text { material radioativo }\end{array}$ & \multirow{3}{*}{$\begin{array}{l}\text { Imersão } \\
(5.1)\end{array}$} & \multirow{3}{*}{$\begin{array}{l}\text { Vazamento } \\
\qquad(5.3)\end{array}$} & \multirow{3}{*}{$\begin{array}{l}\text { Imersão } \\
(5.1)\end{array}$} & \multirow{3}{*}{$\begin{array}{l}\text { Vazamento } \\
\text { (5.3) }\end{array}$} \\
\hline A1 & $\begin{array}{l}\text { Janela única e fina, por } \\
\text { exemplo detectores de } \\
\text { fumaça }\end{array}$ & & & & \\
\hline $\mathrm{A} 2$ & $\begin{array}{c}\text { Fontes de referencia de baixa } \\
\text { atividade, por exemplo, } \\
\text { encapsuladas em plástico }\end{array}$ & & & & \\
\hline A3 & $\begin{array}{l}\text { Fontes encapsuladas uma } \\
\text { ou duas vezes (excluindo } \\
\text { trítio e rádio) para medição, } \\
\text { radiografia e braquiterapia }\end{array}$ & $\begin{array}{l}\text { Imersão } \\
\quad(5.1) \\
\text { Hélio (6.1) }\end{array}$ & Bolhas (6.2) & $\begin{array}{l}\text { Imersão } \\
\quad(5.1) \\
\text { Hélio }(6.1)\end{array}$ & Bolhas (6.2) \\
\hline A4 & $\begin{array}{c}\text { Fontes encapsuladas uma ou } \\
\text { duas vezes de rádio e outras } \\
\text { fontes gasosas }\end{array}$ & $\begin{array}{c}\text { Emanação } \\
\text { gasosa (5.2) }\end{array}$ & $\begin{array}{l}\text { Imersão } \\
(5.1)\end{array}$ & $\begin{array}{c}\text { Emanação } \\
\text { gasosa (5.2) }\end{array}$ & $\begin{array}{l}\text { Imersão } \\
(5.1)\end{array}$ \\
\hline A5 & $\begin{array}{l}\text { Fontes encapsuladas duas } \\
\text { vezes para teleterapia e } \\
\text { fontes de alta atividade de } \\
\text { irradiação }\end{array}$ & Hélio (6.1) & $\begin{array}{c}\text { Vazamento } \\
(5.3 .2)\end{array}$ & $\begin{array}{l}\text { Imersão } \\
\quad(5.1) \\
\text { Hélio }(6.1)\end{array}$ & Bolhas (6.2) \\
\hline$B$ & $\begin{array}{l}\text { Fontes simuladas seladas } \\
\text { dos tipos A3, A4 e A5 }\end{array}$ & & & $\begin{array}{c}\text { Imersão } \\
\quad(5.1) \\
\text { Hélio }(6.1)\end{array}$ & Bolhas (6.2) \\
\hline C & $\begin{array}{l}\text { Fontes seladas tipo } \\
\text { "Dummy" }\end{array}$ & & & Hélio (6.1) & Bolhas (6.2) \\
\hline
\end{tabular}

Obs: Os números entre parênteses referem-se aos itens da norma.

As fontes para braquiterapia são classificadas como $\mathrm{A} 3$, e os métodos de ensaio preferidos tanto para classificação como para o controle de qualidade 
na produção são os de imersão (5.1) ou de hélio (6.1). O ensaio com gás hélio para que seja válido, necessita que o volume interno livre da fonte selada seja igual ou maior que $0,1 \mathrm{~cm}^{3}$. A semente de iodo-125 possui volume interno livre de apenas $0,0014 \mathrm{~cm}^{3}$. Sendo assim este tipo de ensaio não pode ser utilizado, restando os ensaios que utilizam o método de imersão. 


\section{OBJETIVOS}

Os objetivos deste trabalho são:

- Estudo e determinação de lay-out do ambiente de confinamento para a realização dos ensaios de estanqueidade,

- determinação dos parâmetros para limpeza e descontaminação das sementes,

- definição de parâmetros para descontaminação de tubulações utilizadas nos experimentos,

- estudo, desenvolvimento e montagem dos dispositivos para os ensaios de estanqueidade,

- determinação de parâmetros para a secagem das sementes;

- execução dos métodos de ensaio de estanqueidade propostos pela norma ISO 9978 - Sealed Radioactive Sources- Leakage Test Methods ${ }^{20}$ para sementes radioativas,

- escolha do método mais adequado para ser utilizado durante a produção das sementes,

- confecção de fluxograma de processo dos ensaios de estanqueidade. 


\section{REVISÃO DA LITERATURA}

\subsection{Braquiterapia}

A descoberta da radioatividade no final do século passado abriu 0 espaço para o desenvolvimento da braquiterapia, um importante recurso para o tratamento do câncer.

A palavra braquiterapia tem origem grega (brachys=curto; terapia= tratamento) e define uma forma de tratamento que envolve a colocação de materiais radioativos junto ao tumor. Os materiais determinam a liberação de altas doses de radiação apenas nas proximidades da área de implantação, sem que um grande número de células normais seja atingido ${ }^{22}$.

As fontes seladas encapsuladas em metais como aço inoxidável, platina ou titânio são dispostas em moldes que podem ser colocadas interna ou externamente à lesão, em tratamentos superficiais, intracavitários ou intersticiais. Os implantes radioativos podem ser temporários ou permanentes, dependendo da localização da lesão e do radioisótopo utilizado.

Estudos de radiobiologia mostraram que a principal vantagem na braquiterapia é que se pode liberar altas doses de radiação em curto intervalo de tempo. Todo o tumor é abrangido pela radiação e os tecidos sadios, ao redor da lesão, recebem uma dose mínima resultando numa razão terapêutica mais eficiente que aquela obtida com a teleterapia ${ }^{23}$.

As sementes de iodo-125 surgiram em 1967, com a patente de Lawrence $^{24}$, sob o título Therapeutic metal seed containing whitin a radioactive isotope disposed on a carrier and method of manufacture.

Os primeiros estudos utilizando as sementes de iodo-125 foram realizados no Memorial Sloan-Kettering Câncer Center, nos Estados Unidos, em 1972, pelo grupo de Whitmore ${ }^{25}$. Os primeiros relatórios foram favoráveis quanto à redução da incontinência urinária e da impotência, porém, evidenciaram que o método não permitia uma distribuição uniforme da dose de radiação na próstata. 
Além disso, a avaliação da qualidade do implante foi seriamente questionada. Com a evolução na prostatectomia radical (retirada da próstata) e o refinamento da técnica de irradiação com feixe externo, diminuiu o interesse pela braquiterapia.

A partir de 1983, avanços tecnológicos renovaram o interesse pela braquiterapia prostática. As tecnologias, como o ultra-som transretal e a tomografia computadorizada, que proporcionou imagens e medidas detalhadas do tamanho e formato da próstata, facilitaram o planejamento, a colocação precisa das sementes e estimularam o uso dessa técnica. A distribuição da dose de radiação pode ser verificada após o implante por tomografia computadorizada ou raios- $\mathrm{X}^{26}$.

A técnica de implante de sementes radioativas guiadas por ultra-som é, sem dúvida, uma das técnicas mais utilizadas e alguns milhares de pacientes têm sido tratados por ela. As fontes radioativas utilizadas são o iodo-125 e o paládio103. Ambos possuem baixa energia média: a do iodo-125 é aproximadamente 29 keV e a do paládio-103 é aproximadamente $20 \mathrm{keV}$, o que traduz curta penetração de radiação por eles emitida $(<-1 \mathrm{~cm}$ no tecido biológico) e, consequentemente, não há necessidade de medidas severas de radio proteção, como o isolamento do paciente. A meia-vida do iodo-125 é 59,4 dias e a do paládio-103 é de 16,96 dias. O iodo-125 leva 4 meses para liberar $80 \%$ da dose, enquanto o paládio-103 leva um pouco mais de 1 mês. Esta diferença sugere que o paládio-103 seria mais adequado nos tumores com alto índice de proliferação, beneficiando-se da liberação rápida da dose e evitando a repopulação tumoral $^{12,27}$.

\subsection{Norma ISO 9978}

A norma ISO $9978^{20}$ trata de ensaios de estanqueidade e se aplica na validação dos ensaios de classificação de protótipos de fontes radioativas seladas, controle de produção das fontes e inspeções periódicas, realizadas a intervalos regulares durante sua vida útil (quando aplicável).

Os métodos recomendados na norma para fontes seladas utilizadas em braquiterapia são em primeira escolha: imersão (5.1) e hélio (6.1), sendo que o método com gás hélio apresenta como ressalva o mínimo volume interno livre da fonte selada. Os métodos de ensaio por imersão são os seguintes: 
- Ensaio de imersão em líquido aquecido a 50 C

Imergir a fonte selada em um líquido que não ataque o material externo da fonte e que, nas condições do ensaio, seja considerado efetivo para remoção de qualquer traço de material radioativo presente. Exemplos desses líquidos são água destilada, água destilada e detergente neutro, agentes quelantes ou ainda soluções alcalinas ou ácidas em concentração em torno de 5\%. Aquecer o líquido a $50^{\circ} \mathrm{C} \pm 5^{\circ} \mathrm{C}$ e manter nessa temperatura por pelo menos 4 horas. Remover a fonte selada e medir a atividade do líquido remanescente..

\section{- Ensaio de imersão em líquido aquecido a 70 C}

Imergir a fonte selada em um líquido que não ataque o material externo da fonte e que, nas condições do ensaio, seja considerado efetivo para remoção de qualquer traço de material radioativo presente. Aquecer o líquido a $70^{\circ} \mathrm{C} \pm 5^{\circ} \mathrm{C}$ e manter nessa temperatura por pelo menos 30 minutos com aplicação simultânea de ultra-som. Remover a fonte selada e medir a atividade do líquido remanescente.

\section{- Ensaio de imersão com líquido fervente}

Imergir a fonte selada em um líquido que não ataque o material externo da fonte e que, nas condições do ensaio, seja considerado efetivo para remoção de qualquer traço de material radioativo presente. Ferver por 10 minutos, deixar esfriar, então enxaguar a fonte em líquido frio. Repetir essa seqüência mais duas vezes, utilizando sempre o mesmo líquido original. Remover a fonte selada e medir a atividade desse líquido.

\section{- Ensaio de imersão com líquido cintilador}

Colocar a fonte selada por pelo menos 3 horas em temperatura ambiente, em solução líquida cintiladora que não ataque o material da superfície externa da fonte. Guardar longe de luz para prevenir fotoluminescência. Remover a fonte selada e medir a atividade do líquido utilizando técnica de contagem com líquido cintilador.

\section{- Ensaio de imersão em temperatura ambiente}

Imergir a fonte selada em um líquido que não ataque o material externo da fonte e que, nas condições do ensaio, seja considerado efetivo para remoção de qualquer traço de material radioativo presente. O líquido deverá estar em 
temperatura ambiente $\left(20^{\circ} \mathrm{C} \pm 5^{\circ} \mathrm{C}\right)$. Manter em imersão por 24 horas. Remover as fontes seladas e medir a atividade do líquido.

\section{- Critério de aprovação}

A fonte selada será considerada isenta de vazamento se a atividade medida no líquido não exceder $185 \mathrm{~Bq}$ ( 5nCi).

A norma ISO $9978^{20}$ traz algumas definições importantes:

a. Fonte radioativa selada: Material radioativo permanentemente selado em uma ou várias cápsulas e/ou associado a um material ao qual se encontra preso. Essa cápsula ou material devem ser resistentes o suficiente para manter a ausência de vazamento na fonte selada, sob as condições de uso e desgaste para as quais foi projetada.

b. Cápsula: Invólucro de proteção, normalmente feito de metal, utilizado para prevenir o vazamento de material radioativo.

c. Ausência de vazamento: Termo aplicado para fontes seladas que, após serem submetidas aos ensaios de estanqueidade foram consideradas isentas de vazamento, segundo o critério estabelecido pela norma (atividade no líquido de imersão menor que $185 \mathrm{~Bq}$ ).

\subsection{Produção de sementes e ensaios por imersão}

Durante a última década, os desenvolvimentos mais importantes em fontes radioativas seladas têm relação com aplicações médicas, incluindo fontes de iodo-125 para tratamento do câncer oftálmico e da próstata.

$\mathrm{Na}$ etapa inicial da produção das sementes o substrato de prata é submetido a um processo onde 0 iodo-125 é fixado por adsorção. A homogeneidade da distribuição do iodo sobre o fio de prata é um item importante na qualidade do produto final, necessitando ser avaliado ${ }^{28}$. Na próxima etapa, a soldagem da cápsula de titânio utiliza dispositivos de posicionamento precisos para se realizar a soldagem, devido às pequenas dimensões da cápsula ${ }^{29}$. Para realizar a solda, diversas tecnologias podem ser utilizadas, incluindo a solda TIG (tungsten inert gás) e solda microplasma ${ }^{30}$, além da solda a laser ${ }^{31}$. Após a soldagem são efetuados ensaios de estanqueidade para garantir a ausência de vazamentos. A literatura relata a realização de ensaios de estanqueidade em sementes de iodo- 125 utilizando métodos de imersão a $20^{\circ} \mathrm{C}$ durante 24 horas e a $50^{\circ} \mathrm{C}$ por 5 horas $^{16,32,33}$. 


\section{MATERIAIS E MÉTODOS}

As atividades laboratoriais realizadas se dividiram em duas etapas. A primeira referente a estudos e simulações das rotinas no ambiente confinado onde acontecerá o processo de controle de qualidade das sementes (ensaio de estanqueidade das sementes). Essas simulações foram feitas no interior da caixa de confinamento localizada no laboratório de produção das sementes, no Centro de Tecnologia das Radiações (CTR), para determinar com precisão como serão as etapas do controle de qualidade, as várias operações, os equipamentos necessários bem como sua disposição física e as dificuldades encontradas. Essas simulações foram feitas sem a utilização de qualquer material radioativo.

A segunda parte foi a execução e avaliação dos vários métodos de ensaios de estanqueidade por imersão nas sementes de iodo-125, utilizando-se capela própria para manuseio de material radioativo, com exaustão e filtragem de ar.

\subsection{Determinação de layout do processo de controle de qualidade}

Foram avaliados o espaço necessário e a disposição dos utensílios na caixa de confinamento (glove box), com a simulação da rotina de ensaio de estanqueidade dentro da estação de trabalho. Foram utilizadas luvas de chumbo e pinças para manipulação dos tubos contendo lotes de sementes. A caixa de confinamento é mostrada na FIG. 8. 


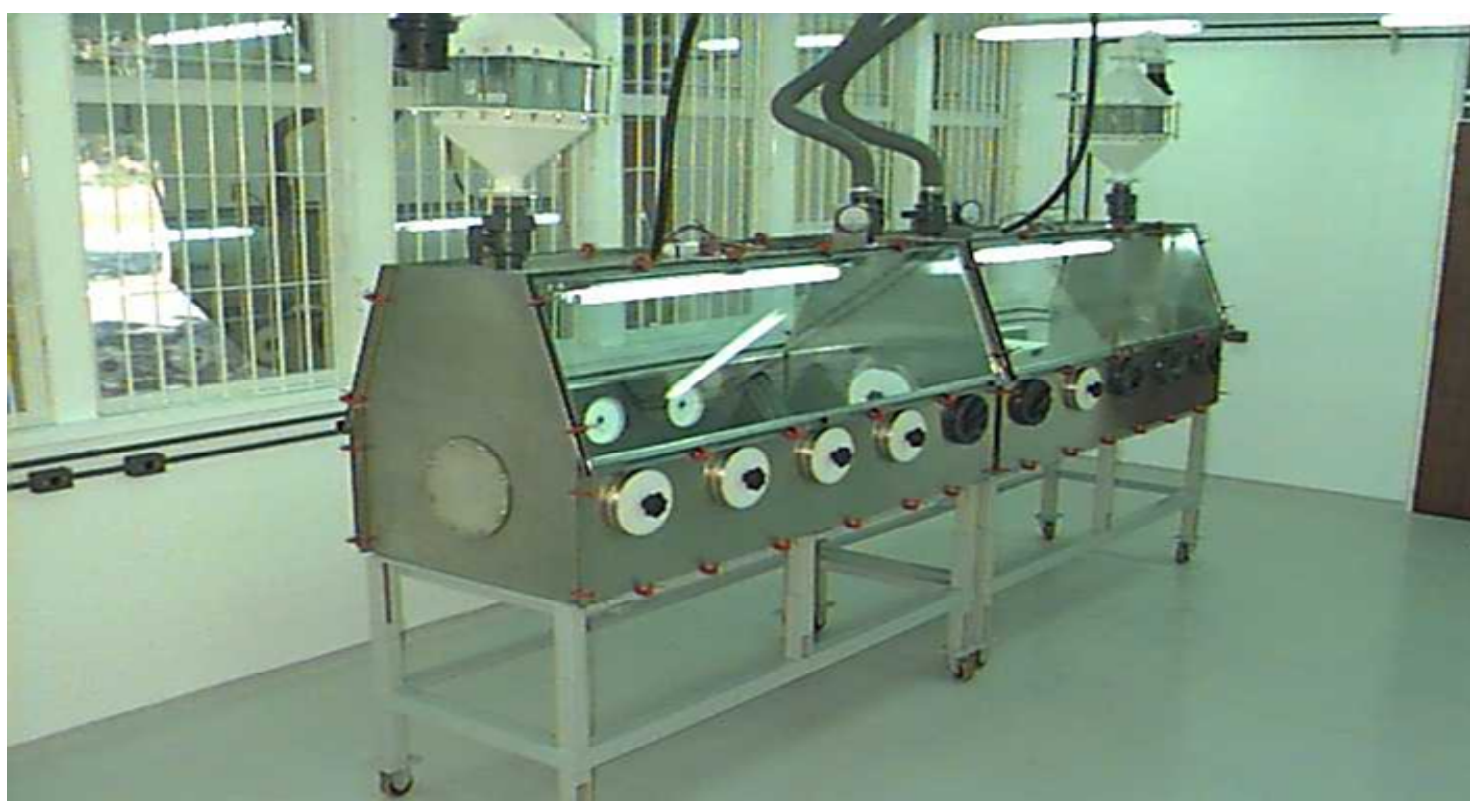

FIGURA 8: Caixa de confinamento.

\subsection{Construção de dispositivos para os ensaios de estanqueidade}

Os protótipos de dispositivos construídos para as simulações e que foram ensaiados são os seguintes:

- Suporte para rolhas de borracha. As rolhas são utilizadas para evitar derramamento de líquido dos tubos durante os ensaios de estanqueidade.

- Suporte para tubos de polietileno utilizado no banho de ultra-som. Permite o posicionamento de vários tubos contendo sementes e líquido, mergulhados na cuba da lavadora ultrasônica, sem que se desprendam.

- Dispositivo para secagem de sementes. Após o término do ensaio de estanqueidade as sementes estão imersas em água destilada onde foram enxaguadas. É necessário retirar a água e secar completamente as sementes. Para tanto foi construído e ensaiado um dispositivo adequado a essa finalidade.

\subsection{Ensaios de secagem das sementes}

Para simular e ensaiar essa operação foi montado um conjunto para secagem composto de suporte e tela de retenção para sementes. O processo de secagem foi realizado de duas maneiras:

- Utilizando para sucção uma bomba de vácuo.

- Utilizando para sucção um aspirador de pó doméstico. 
Em ambos os casos foi avaliado o tempo necessário para a completa secagem das sementes. $O$ roteiro dos ensaios foi o seguinte:

1. Imersão de um lote de 30 sementes inativas (sem atividade) em água destilada num tubo de polietileno.

2. Transferência de todo o conteúdo do tubo (água + sementes) para o sistema de retenção (tubo de PVC + tela) montado sobre recipiente de vidro (kitasato).

3. O equipamento de sucção (bomba de vácuo ou aspirador de pó) foi ligado durante determinado tempo e o resultado foi avaliado.

4. Repetidos os itens 1 a 3 aumentando-se gradativamente o tempo, até atingir um resultado satisfatório.

Para realização desses ensaios foi utilizado pipetador EPPENDORF Multipette plus, bomba de vácuo EDWARDS modelo E2M2, aspirador de pó ELETROLUX modelo NEO-1200W, tubos de polietileno, sementes de iodo-125 inativas, dispositivo para secagem e água destilada.

\subsection{Descontaminação de lote de sementes}

Durante o processo de produção das sementes de iodo-125 pode ocorrer contaminação da superfície externa das mesmas com material radioativo, necessitando limpeza e descontaminação. Para determinar o procedimento de descontaminação dos lotes de sementes foram simuladas contaminações, utilizando iodo-131. Este radioisótopo foi escolhido porque seu comportamento químico é o mesmo do iodo-125, a meia-vida é de apenas 8 dias e está disponível no IPEN. A simulação consistiu em colocar certa quantidade de iodeto de sódio (iodo-131) diluído em água destilada em um tubo de polietileno contendo um lote de 30 sementes inativas (sem atividade). Após a contaminação superficial das sementes foram feitas diversas lavagens com água em uma lavadora ultrasônica. Após cada uma das lavagens foi retirada a água de lavagem e sua atividade foi medida. As sementes foram consideradas descontaminadas quando a atividade detectada ficou abaixo do limite de $5 \mathrm{nCi}(185 \mathrm{~Bq})$ estipulado pela norma ISO $9978^{20}$ (ensaios de estanqueidade). O roteiro do experimento foi o seguinte:

1. Em um tubo contendo 30 sementes inativas foi adicionada uma solução contendo $2 \mathrm{ml}$ de água destilada e $1 \mathrm{mCi}(37 \mathrm{MBq})$ de iodo- 131 .

2. O tubo foi tampado com uma rolha, agitado manualmente para homogeneização e deixado em repouso por 5 minutos. 
3. Em seguida foi colocado em banho com ultra-som por 10 minutos.

4. A solução radioativa foi retirada e armazenada em blindagem de chumbo.

5. Nas sementes remanescentes adicionou-se $2 \mathrm{ml}$ de água destilada e colocouse em banho com ultra-som por 10 minutos.

6. Retirou-se a água do tubo e mediu-se a sua atividade.

7. Repetiu-se os itens 5 e 6 até que a atividade medida no líquido estivesse abaixo de $5 \mathrm{nCi}(185 \mathrm{~Bq})$.

8. Repetiu-se o experimento, desta vez adicionando detergente na água de lavagem (150 $\mu \mathrm{L}$ Extran 10\%).

Os equipamentos e materiais utilizados foram: medidor de radiação CAPINTEC modelo CRC $15 \mathrm{~W}$ com detector de iodeto de sódio tipo poço e câmara de ionização, lavadora ultrasonica AMSCO Reliance Sonic 75, pipeta de volume fixo $1 \mathrm{ml}$, água destilada, iodo-131 na forma de iodeto de sódio, tubos de polietileno.

\subsection{Descontaminação da tubulação de transferência de líquidos}

Durante o ensaio de estanqueidade é necessário fazer a transferência de líquidos entre recipientes, utilizando-se mangueiras plásticas. Caso ocorra vazamento de material radioativo das sementes, as mangueiras serão contaminadas e devem ser descontaminadas antes de serem utilizadas novamente. Para determinar um método de descontaminação das mangueiras, foi realizado um experimento, provocando-se uma contaminação intencional e posterior descontaminação. Utilizou-se $1 \mathrm{mCi}(37 \mathrm{MBq})$ de iodo-131 na forma de iodeto de sódio, diluído em $2 \mathrm{ml}$ de água destilada, para a contaminação da mangueira. Diferentes volumes de água destilada com diversos valores de vazão foram transferidos através das mangueiras, com o intuito de retirar o material contaminante. Dois dispositivos de bombeamento foram utilizados: uma bomba peristáltica e uma bomba de vácuo. Dois tipos de mangueiras foram utilizados: mangueira de borracha de silicone e mangueira de politetrafluoretileno (PTFE). A mangueira de silicone foi utilizada em conjunto com a bomba peristáltica devido a sua flexibilidade, possibilitando o esmagamento pelos roletes da bomba, condição necessária para estabelecer o fluxo.

A mangueira de PTFE foi utilizada juntamente com o sistema de bombeamento a vácuo devido à sua rigidez, resistindo ao efeito de colabamento. 
Além disso, o PTFE é reconhecido por apresentar superfície lisa e comportamento químico inerte, resistindo à impregnação de substâncias ${ }^{34}$.

Foram realizados cinco diferentes tipos de ensaio. Quatro deles utilizando bomba peristáltica e mangueira de silicone e um utilizando bomba de vácuo e mangueira de PTFE. Utilizou-se bomba peristáltica Perista- Mini Pump da ATTO Corporation, bomba de vácuo Edwards modelo EM2, mangueira de silicone diâmetro interno de $1 \mathrm{~mm}$ e parede de $0,7 \mathrm{~mm}$, mangueira de PTFE (Teflon), diâmetro interno de $1 \mathrm{~mm}$ e parede de $0,27 \mathrm{~mm}$, pipeta de volume fixo $1 \mathrm{ml}$, iodo 131 (iodeto de sódio), balão volumétrico de $200 \mathrm{ml}$, becker de $200 \mathrm{ml}$, medidor de radiação CAPINTEC modelo $\mathrm{CRC} 15 \mathrm{~W}$ com detector de iodeto de sódio tipo poço e câmara de ionização, tubos de polietileno, rolhas de borracha, água destilada.

Foi montado o circuito esquematizado na FIG. 9 utilizando-se uma bomba peristáltica para impulsionar o líquido pela mangueira de silicone, fazendo a transferência entre os tubos.

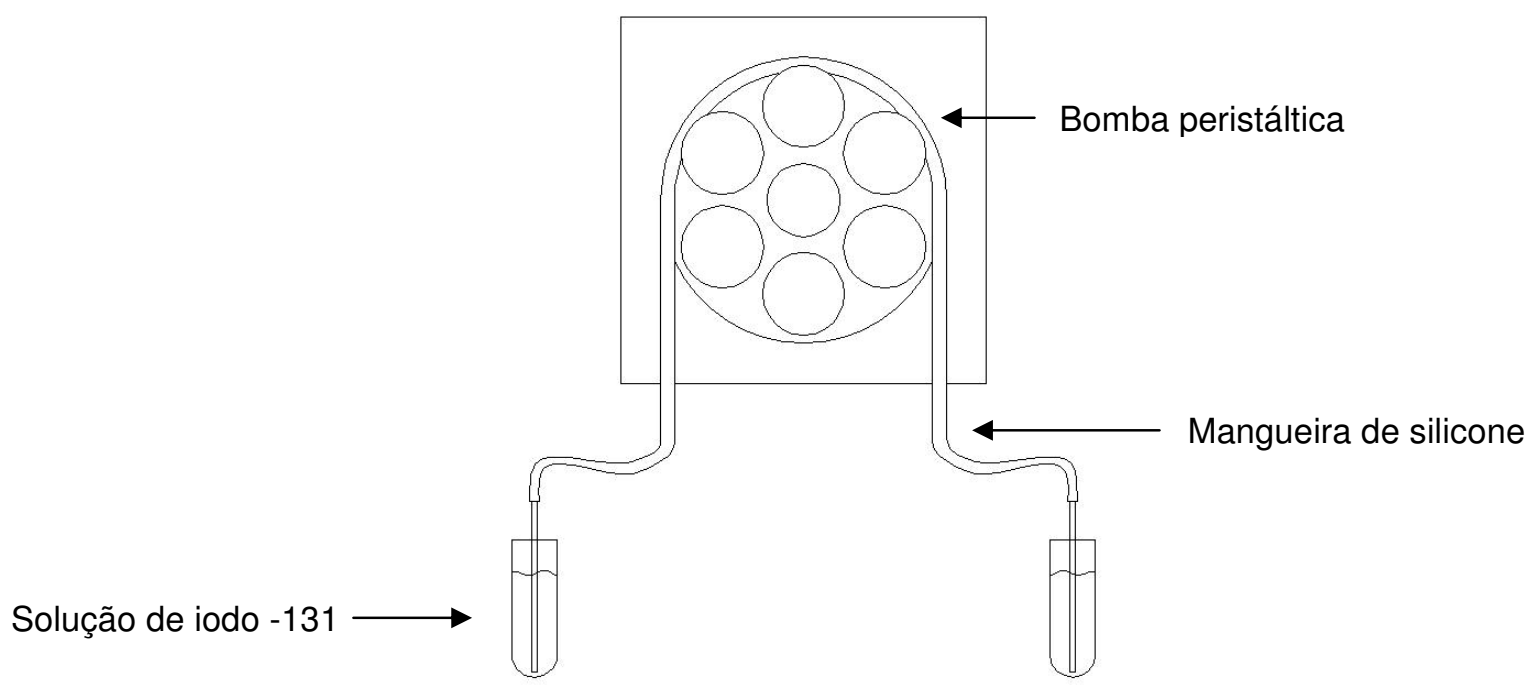

FIGURA 9: Sistema de transferência com bomba peristáltica.

Foi montado o circuito esquematizado na FIG. 10, utilizando-se uma bomba de vácuo para impulsionar o líquido pela mangueira de PTFE, fazendo a transferência entre os tubos. 


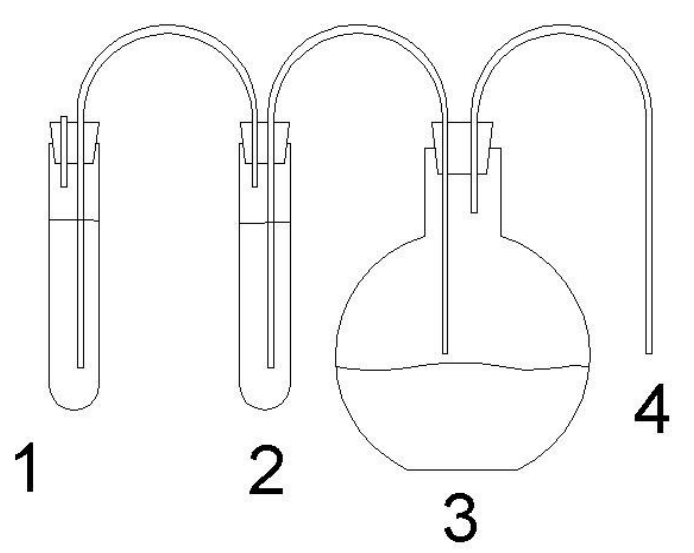

FIGURA 10: Sistema de transferência através de bomba de vácuo.

1. Tubo contendo solução de iodo-131

2. Tubo intermediário

3. Balão de contenção de rejeito

4. Saída para o sistema de sucção por vácuo

No ensaio $\mathrm{n}$-1 a mangueira de silicone foi contaminada transferindo-se $1 \mathrm{mCi}$ de iodo-131, diluído em $2 \mathrm{ml}$ de água destilada. Em seguida foram transferidos $2 \mathrm{ml}$ de água destilada para limpeza da mangueira e sua atividade foi medida. A última etapa foi repetida até a estabilização do valor de atividade, após seu decréscimo. A velocidade do líquido na mangueira foi de 3,3 $\mathrm{ml} / \mathrm{minuto}$ utilizando-se bomba peristáltica. Duas séries de 30 lavagens foram realizadas.

No ensaio no 2 a mangueira de silicone foi contaminada transferindo-se $1 \mathrm{mCi}$ de iodo-131, diluído em $2 \mathrm{ml}$ de água destilada. Em seguida foram transferidos 50ml de água destilada para limpeza da mangueira. Após a limpeza, foram transferidos $2 \mathrm{ml}$ de água destilada e sua atividade foi medida. A velocidade do líquido na mangueira foi de $3,3 \mathrm{ml} /$ minuto utilizando-se bomba peristáltica. $O$ ensaio foi feito em duas séries de 15 repetições.

No ensaio $\mathrm{n}-3$ foi realizado o mesmo procedimento do ensaio $\mathrm{n}-2$, porém com maior velocidade do líquido $(9 \mathrm{ml} /$ minuto). O ensaio foi repetido 10 vezes.

No ensaio $\mathrm{n}$-4 foi realizado o mesmo procedimento do ensaio $\mathrm{n}$ 으, porém com maior volume de água na limpeza $(75 \mathrm{ml})$. O ensaio foi repetido 30 vezes. 
No ensaio nำ a mangueira de PTFE foi contaminada transferindo-se $1 \mathrm{mCi}$ de iodo-131, diluído em $2 \mathrm{ml}$ de água destilada. Em seguida foram transferidos $75 \mathrm{ml}$ de água destilada para limpeza da mangueira. Após a limpeza, foram transferidos $2 \mathrm{ml}$ de água destilada e sua atividade foi medida. A velocidade do líquido na mangueira foi de $45 \mathrm{ml} /$ minuto utilizando-se bomba de vácuo. $\mathrm{O}$ ensaio foi repetido 90 vezes.

\subsection{Influência da variação de parâmetros nos métodos recomendados}

A norma ISO $9978^{20}$ estabelece as condições básicas para os ensaios de estanqueidade, sugerindo algumas alterações. As variações foram avaliadas e em certos casos excedeu-se a severidade da norma, como nos ensaios em temperatura ambiente $\left(20^{\circ} \mathrm{C}\right)$ e em temperatura de $50^{\circ} \mathrm{C}$. Esses dois métodos foram escolhidos devido à sua relativa simplicidade quando comparados aos demais (imersão em líquido a $70^{\circ} \mathrm{C}$, imersão em líquido cintilador e imersão em líquido fervente). Foram utilizadas duas sementes de iodo-125, inicialmente medindo-se suas atividades. Em seguida as sementes foram cortadas ao meio utilizando-se um alicate de corte e procedeu-se aos ensaios. A seqüência e os parâmetros desse experimento estão descritos na TAB. 5.

TABELA 5: Variações ensaiadas nos métodos por imersão.

\begin{tabular}{|c|c|c|c|}
\hline \multicolumn{2}{|c|}{ Semente $\mathrm{n}=1(1,68 \mathrm{kbq})$ - Ensaios a $20^{\circ} \mathrm{C}$} & \multicolumn{2}{|c|}{ Semente $\mathrm{n}^{\circ} 2(1,66 \mathrm{kBq})$ - Ensaios a $50^{\circ} \mathrm{C}$} \\
\hline $\begin{array}{l}\text { Método } \\
\text { recomendado } \\
\text { pela norma } \\
\text { (1) }\end{array}$ & $\begin{array}{l}\text { Imersão por } 24 \text { horas em água } \\
\text { destilada }(2 \mathrm{ml}) \text { à temperatura } \\
\text { ambiente }\left(20^{\circ} \mathrm{C} \pm 5^{\circ} \mathrm{C}\right)\end{array}$ & $\begin{array}{l}\text { Método } \\
\text { recomendado } \\
\text { pela norma } \\
\text { (1) }\end{array}$ & $\begin{array}{c}\text { Imersão por } 4 \text { horas em água } \\
\text { destilada }(2 \mathrm{ml}) \text { à temperatura de } \\
50^{\circ} \mathrm{C} \pm 5^{\circ} \mathrm{C}\end{array}$ \\
\hline $\begin{array}{c}\text { Variação } n^{\circ} 1 \\
(2)\end{array}$ & $\begin{array}{l}\text { Imersão por } 24 \text { horas em água } \\
\text { destilada }(2 \mathrm{ml})+150 \text { ul } \\
\text { detergente à temperatura } \\
\text { ambiente }\left(20^{\circ} \mathrm{C} \pm 5^{\circ} \mathrm{C}\right)\end{array}$ & $\begin{array}{c}\text { Variação } n^{\circ} 1 \\
\text { (2) }\end{array}$ & $\begin{array}{c}\text { Imersão por } 4 \text { horas em água } \\
\text { destilada }(2 \mathrm{ml})+150 \mathrm{ul} \\
\text { detergente à temperatura de } 50^{\circ} \\
\mathrm{C} \pm 5^{\circ} \mathrm{C}\end{array}$ \\
\hline $\begin{array}{c}\text { Variação } n^{\circ} 2 \\
\text { (3) }\end{array}$ & $\begin{array}{l}\text { Imersão por } 24 \text { horas em água } \\
\text { destilada }(2 \mathrm{ml})+150 \text { ul } \mathrm{HClO}_{4} \\
(\mathrm{pH}=1,5) \text { à temperatura } \\
\text { ambiente }\left(20^{\circ} \mathrm{C} \pm 5^{\circ} \mathrm{C}\right)\end{array}$ & $\begin{array}{c}\text { Variação } n^{\circ} 2 \\
\text { (3) }\end{array}$ & $\begin{array}{c}\text { Imersão por } 4 \text { horas em água } \\
\text { destilada }(2 \mathrm{ml})+150 \text { ul } \mathrm{HClO}_{4} \\
(\mathrm{pH}=1,5) \text { à temperatura de } 50^{\circ} \\
\mathrm{C} \pm 5^{\circ} \mathrm{C} \text {. }\end{array}$ \\
\hline $\begin{array}{l}\text { Variação } n^{\circ} 3 \\
\text { (excedeu a } \\
\text { norma) } \\
(4)\end{array}$ & $\begin{array}{c}\text { Imersão por } 24 \text { horas em água } \\
\text { destilada }(2 \mathrm{ml}) \text { à temperatura } \\
\text { ambiente }\left(20^{\circ} \mathrm{C} \pm 5^{\circ} \mathrm{C}\right), 10 \text { min. } \\
\text { Ultra-som. }\end{array}$ & $\begin{array}{l}\text { Variação } n^{\circ} 3 \\
\text { (excedeu a } \\
\text { norma) } \\
\text { (4) }\end{array}$ & $\begin{array}{l}\text { Imersão por } 4 \text { horas em água } \\
\text { destilada }(2 \mathrm{ml}) \text { à temperatura de } \\
50^{\circ} \mathrm{C} \pm 5^{\circ} \mathrm{C}, 30 \mathrm{~min} \text {. Ultra-som. }\end{array}$ \\
\hline
\end{tabular}

Obs: Os números entre parênteses indicam a ordem da realização dos ensaios. 
Foram utilizados pipeta de volume fixo $1 \mathrm{ml}$, medidor de radiação CAPINTEC modelo CRC $15 \mathrm{~W}$ com detector de iodeto de sódio tipo poço e câmara de ionização, lavadora ultrasonica AMSCO Reliance Sonic 75, tubos de polietileno, rolhas de borracha, alicate de corte, água destilada, detergente EXTRAN em solução a 10\%, ácido perclórico $\left(\mathrm{HClO}_{4}\right)$, ph $=1,5$.

\subsection{Ensaios de estanqueidade}

Para determinar qual tipo de ensaio seria o mais adequado ao processo de fabricação de sementes de iodo-125 no IPEN, executaram-se os cinco tipos de ensaios de imersão classificados pela norma como preferidos:

1. Ensaio de imersão em líquido cintilador;

2. Ensaio de imersão em líquido a $20^{\circ} \mathrm{C}$ (com a inclusão de aplicação de ultrasom);

3. Ensaio de imersão em líquido aquecido a $50^{\circ} \mathrm{C}$ (com a inclusão de aplicação de ultra-som);

4. Ensaio de imersão em líquido aquecido a $70^{\circ} \mathrm{C}$ e aplicação de ultra-som;

5. Ensaio de imersão em líquido fervente.

O roteiro básico dos ensaios é composto de:

- limpeza criteriosa da superfície externa da fonte (realizada anteriormente pelo fabricante das sementes);

- imersão da fonte em líquido a uma determinada temperatura e por determinado período de tempo;

- retirada da fonte;

- medida da atividade do líquido de imersão.

Cada um dos cinco ensaios foi realizado em 20 sementes, perfazendo um total de 100 sementes de iodo-125 que possuem características construtivas similares àquelas que serão produzidas pelo IPEN. Inicialmente foi medida a atividade de cada uma das sementes e foram colocadas individualmente em tubos plásticos numerados (tubos numerados de 1 a 100).

Em seguida foi provocado vazamento em cada uma das sementes através de um pequeno corte na sua extremidade, utilizando um dispositivo composto de suporte de fixação da semente e disco de corte diamantado. O disco gira a uma velocidade ajustável e provoca uma ranhura, permitindo a passagem do material interior à semente para o meio externo. Na FIG. 11 são mostrados uma 
imagem do sistema de corte (a) e um esquema da operação do corte da semente (b). Foi efetuada limpeza no disco diamantado após cada operação para evitar ao máximo a contaminação do mesmo e contaminação cruzada entre sementes. Após a medição da atividade e de ter sido submetida à operação de corte, cada semente foi devolvida ao tubo correspondente e o mesmo foi tampado com rolha de borracha até o momento da realização do ensaio.

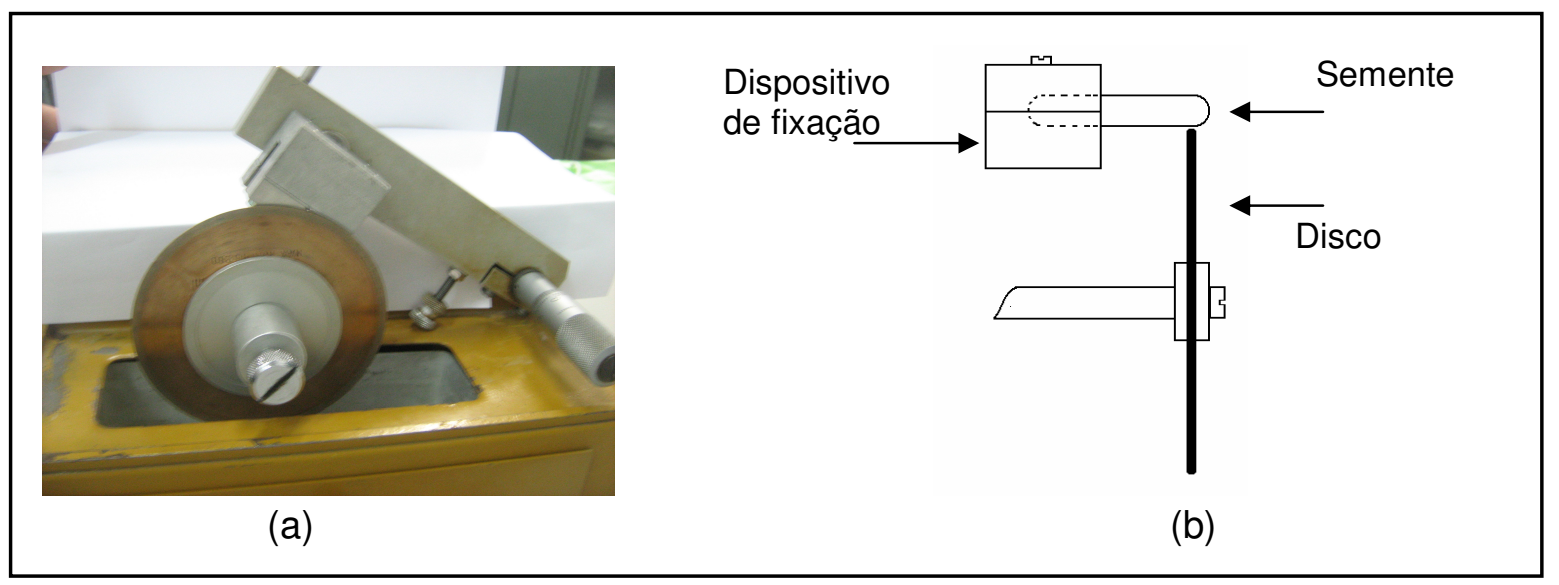

FIGURA 11: Sistema de corte (a) e operação de corte (b).

Os cinco métodos de ensaio por imersão foram realizados da seguinte maneira:

\section{- Experimento no 1: Imersão em líquido cintilador.}

Os tubos de $\mathrm{n}^{\circ}$ a 20 , contendo as sementes, foram preenchidos com $10 \mathrm{ml}$ de líquido cintilador e tampados com rolha de borracha permanecendo em imersão por 4 horas a temperatura ambiente. As sementes foram então retiradas e a atividade do líquido foi medida utilizando-se contador de cintilação líquida.

\section{- Experimento $n^{\circ} 2$ : Imersão em água com temperatura de $20^{\circ} \mathrm{C}$.}

Os tubos de $\mathrm{n}^{\circ} 21$ a 40 , contendo as sementes, foram preenchidos com $2 \mathrm{ml}$ de água destilada e tampados com rolha de borracha, permanecendo em imersão a temperatura ambiente $\left(20^{\circ} \mathrm{C} \pm 5^{\circ} \mathrm{C}\right)$ por 24 horas. No início desse período foi aplicado ultra-som por 10 minutos. As sementes foram então removidas e a atividade do líquido foi medida.

\section{- Experimento n 3: Imersão em água aquecida a 50ㄷ.}

Os tubos de $\mathrm{n}^{\circ} 41$ a 60 , contendo as sementes, foram preenchidos com $2 \mathrm{ml}$ de água destilada e tampados com rolha de borracha, permanecendo em imersão a temperatura de $50^{\circ} \mathrm{C} \pm 5^{\circ} \mathrm{C}$ durante 4 horas. No início desse período foi 
aplicado ultra-som por 30 minutos. As sementes foram então removidas e a atividade do líquido foi medida.

\section{- Experimento no 4: Imersão em água aquecida a 70C.}

Os tubos de $\mathrm{n}^{\circ} 61$ a 80 , contendo as sementes, foram preenchidos com $2 \mathrm{ml}$ de água destilada e tampados com rolha de borracha, permanecendo em imersão a temperatura de $70^{\circ} \mathrm{C} \pm 5^{\circ} \mathrm{C}$ durante 30 minutos com aplicação simultânea de ultra-som. As sementes foram então removidas e a atividade do líquido foi medida.

\section{- Experimento no 5: Imersão em água fervente.}

As sementes dos tubos de $\mathrm{n}^{\circ} 81$ a 100 foram colocadas cada uma em um becker contendo $4 \mathrm{ml}$ de água destilada. O becker foi então tampado e aquecido, permanecendo a água em fervura por 10 minutos. $O$ aquecimento foi desligado permitindo resfriamento até a temperatura ambiente. A água da fervura foi retirada e reservada. A semente foi enxaguada com água destilada que foi descartada como rejeito contaminado. A água da fervura foi recolocada no becker com a semente e a seqüência foi repetida por mais duas vezes, totalizando três ciclos. A semente foi então removida e a atividade da água da fervura foi medida.

Para medidas de atividade utilizaram-se medidor de radiação CAPINTEC modelo CRC $15 \mathrm{~W}$ com detector de iodeto de sódio tipo poço e câmara de ionização e o contador de cintilação líquida Packard/Camberra modelo Tri-Carb 1600 TR. Para aplicação de ultra-som utilizou-se lavadora ultrasonica AMSCO Reliance Sonic $75,75 \mathrm{~W}, 40 \mathrm{kHz}$, com aquecimento controlado. Foram utilizados pipeta de volume fixo $1 \mathrm{ml}$ com ponteiras descartáveis, tubos de polietileno e rolhas de borracha. Para o líquido de imersão utilizaram-se água destilada e líquido cintilador Insta-gel, da empresa Perkin Elmer. O corte das sementes foi feito com máquina de corte BUEHLER-Isomet, disco diamantado BUEHLER 11-4244 com diâmetro de $102 \mathrm{~mm}$ e largura de 0,3 mm. Foi utilizado termômetro de coluna de mercúrio com escala $0 \mathrm{a}+100^{\circ} \mathrm{C}$ e termômetro com registro de máxima e mínima temperaturas com escala $-38 \mathrm{a}+50^{\circ} \mathrm{C}$.

$\mathrm{O}$ estudo e simulação das diversas etapas dos ensaios mostraram a necessidade da adaptação de alguns dispositivos laboratoriais e o desenvolvimento de protótipos específicos. Os protótipos construídos no laboratório de braquiterapia e na oficina mecânica do CTR foram o suporte para 
rolhas cônicas de borracha, suporte para tubos de polietileno utilizado no banho de ultra-som e dispositivo para secagem de sementes.

\subsection{Correção dos resultados devido ao decaimento}

Os ensaios com as sementes foram realizados em seqüência e em diferentes datas. Devido ao decaimento da atividade ao longo do tempo em relação ao valor da meia vida do iodo-125 (59,4 dias), os resultados do ensaio foram ajustados, tendo como base a data da medição da atividade das sementes e a data de realização do primeiro ensaio de cada experimento. Para cálculo de ajuste foi utilizada a equação de decaimento ${ }^{12}$ :

$$
A=A_{0} \cdot e^{-\left(\frac{\ln 2}{T 1 / 2}\right) \cdot \Delta t}
$$

Onde:

$\mathrm{A}=$ atividade atual $(\mathrm{Bq})$;

Ao = atividade inicial $(\mathrm{Bq})$;

$\mathrm{T} 1 / 2$ = Tempo de meia vida do radioisótopo, em dias;

$\Delta \mathrm{t}=$ tempo transcorrido entre a data de referência (inicial) e a data atual, em dias.

\subsection{Estimativa da incerteza das medições}

Para avaliar a incerteza dos resultados obtidos foram considerados os erros advindos do equipamento de medição e o erro aleatório, inerente ao processo de medição, incluindo a atuação do operador ${ }^{35}$.

Foi adotado como valor para o erro do equipamento o valor declarado pelo fabricante. Para estimar o erro aleatório, foram realizadas duas séries de 10 medidas, cada uma das séries executadas por um operador, utilizando-se uma semente de iodo-125. O procedimento foi executado procurando-se reproduzir fielmente as condições presentes durante os experimentos, utilizando-se os mesmos equipamentos e acessórios e seguindo a mesma rotina.

Os resultados obtidos foram:

- $\mathrm{E} 1$ = Erro do equipamento: $\pm 2 \%$ do valor medido;

- E2 = Erro aleatório: $\pm 0,82 \%$ do valor medido; 
- Incerteza combinada: $\pm 2,16 \%$ do valor medido;

Para o cálculo da incerteza combinada foi utilizada a fórmula ${ }^{35}$ :

$$
\text { Incerteza combinada }=\sqrt{E 1^{2}+E 2^{2}}
$$




\section{RESULTADOS E DISCUSSÕES}

\subsection{Layout da caixa de confinamento}

Todas as manipulações são feitas dentro da caixa de confinamento, vestindo-se as luvas de chumbo, fator que limita os movimentos. Essa condição dificulta a precisão dos movimentos e exige grande destreza e habilidade do operador, uma vez que os objetos utilizados são de pequenas dimensões (tubos de plástico, pipetas, pinças, rolhas de borracha, embalagens de vidro, entre outros). Os resultados obtidos serviram de base para o projeto mecânico de utensílios, posicionamento dos equipamentos e poderão ser utilizados para futura automação das diversas operações. A FIG. 12 ilustra esquematicamente a disposição dos equipamentos no interior da caixa. Inclui também compartimento de segregação, destinado ao manuseio de lotes de sementes contaminadas separadamente do fluxo normal da produção.

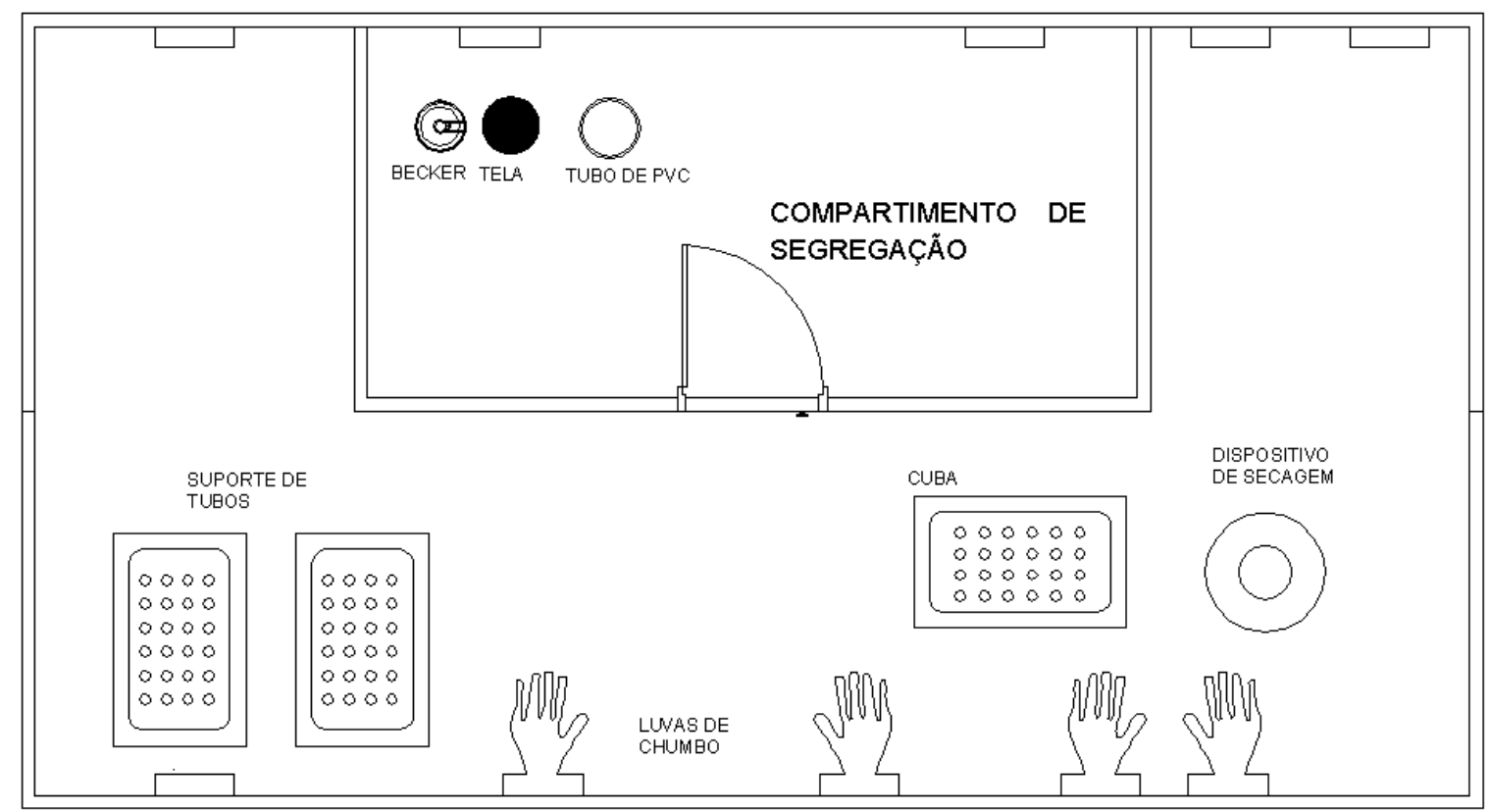

FIGURA 12: Desenho esquemático da disposição dos equipamentos no interior da caixa de confinamento. 


\subsection{Dispositivos construídos para os ensaios}

O suporte para rolhas de borracha foi construído em chapa de acrílico perfurada, com apoios nas extremidades e capacidade para conter 20 rolhas cônicas de borracha. As dimensões do suporte foram determinadas para utilizar o menor volume possível dentro da caixa de confinamento e permitir a colocação e retirada das rolhas com pinças, manipuladas com as luvas de chumbo. A FIG. 13 mostra um esquema do suporte.

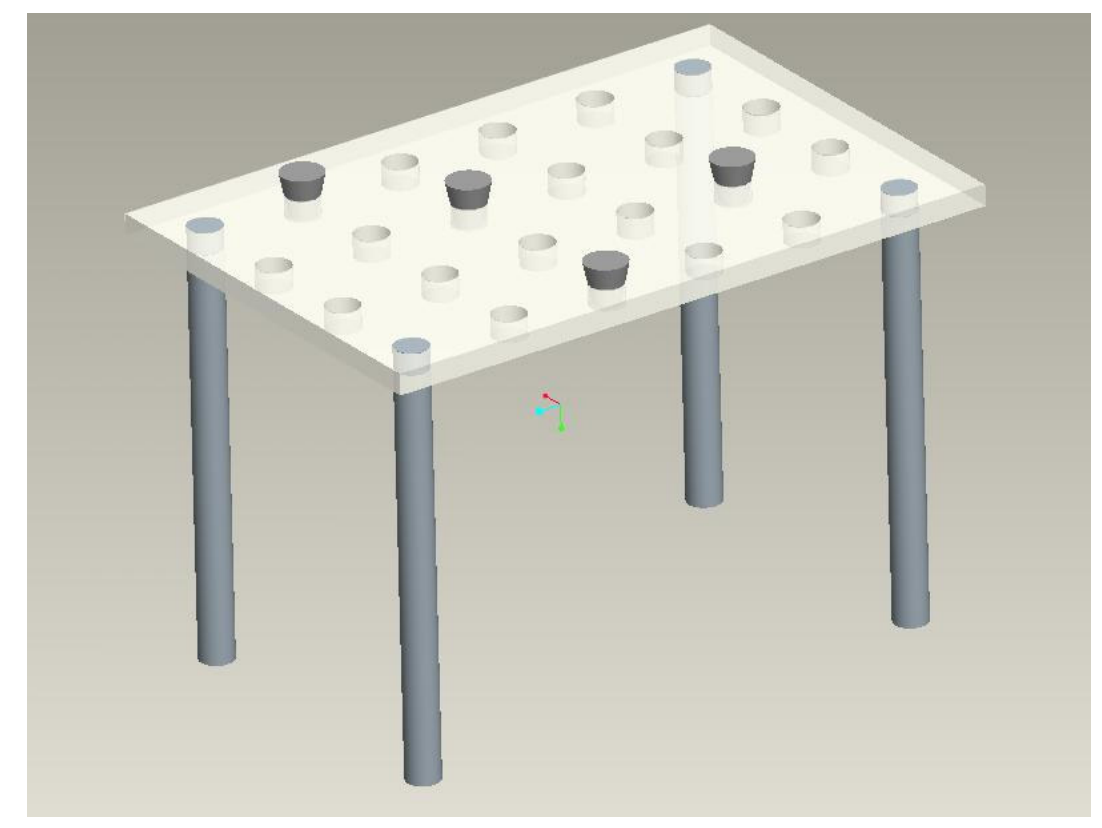

FIGURA 13: Esquema do suporte para rolhas cônicas de borracha.

Foi construído um suporte para tubos a ser utilizado em conjunto com a lavadora ultrasônica. O tamanho do suporte, as distâncias entre tubos e seu posicionamento no sentido vertical estão adequados ao espaço disponível e permitem manipulação dos tubos através de pinças. A FIG. 14 mostra o desenho do suporte (a) e sua utilização (b). 


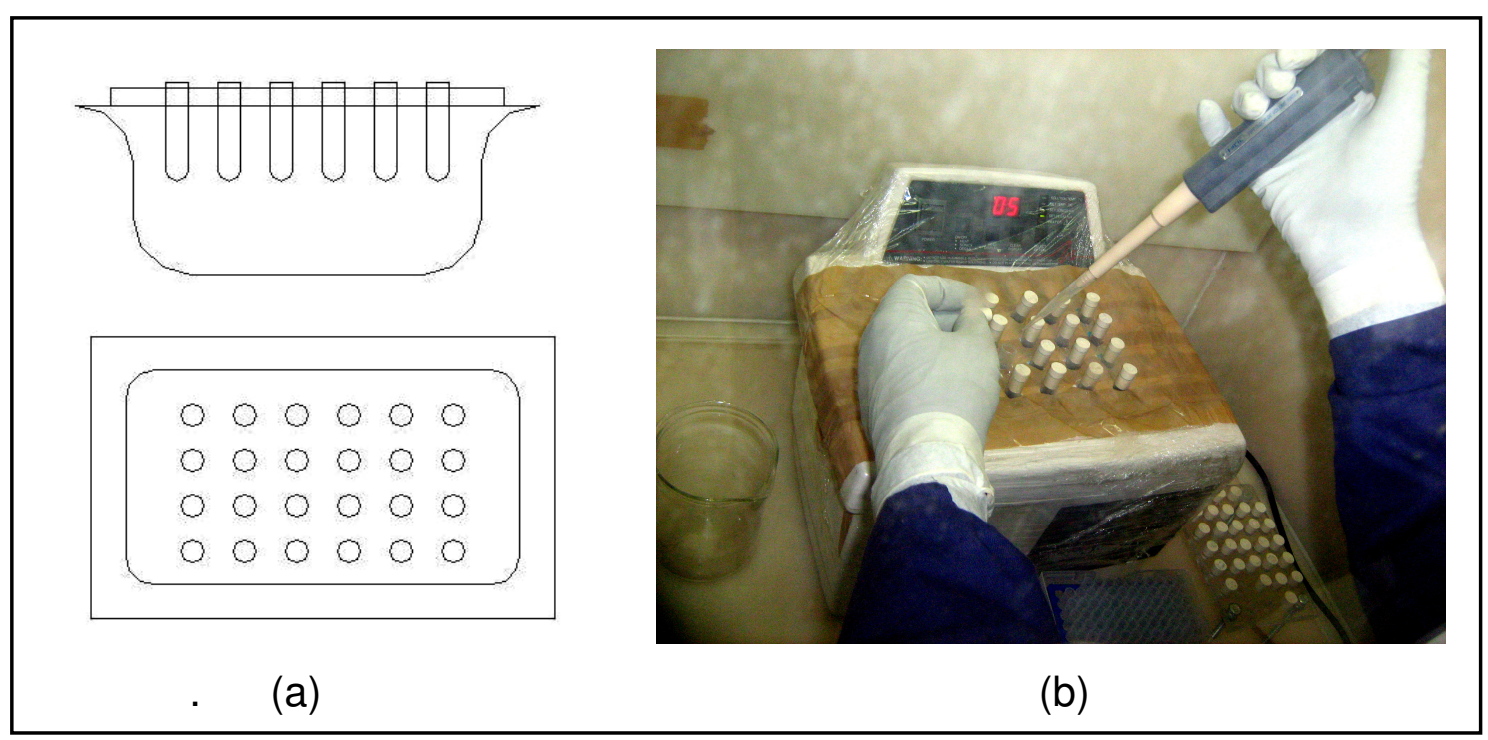

FIGURA 14: Desenho do suporte para tubos (a) e sua utilização (b).

O dispositivo para secagem de sementes é composto de um recipiente de vidro (Kitasato) e um conjunto para suporte do tubo de secagem e tela de retenção de sementes. Na saída do recipiente é ligada uma mangueira para sucção da água, realizada com bomba de vácuo e com um aspirador de pó doméstico. A FIG. 15 mostra um desenho esquemático do dispositivo.

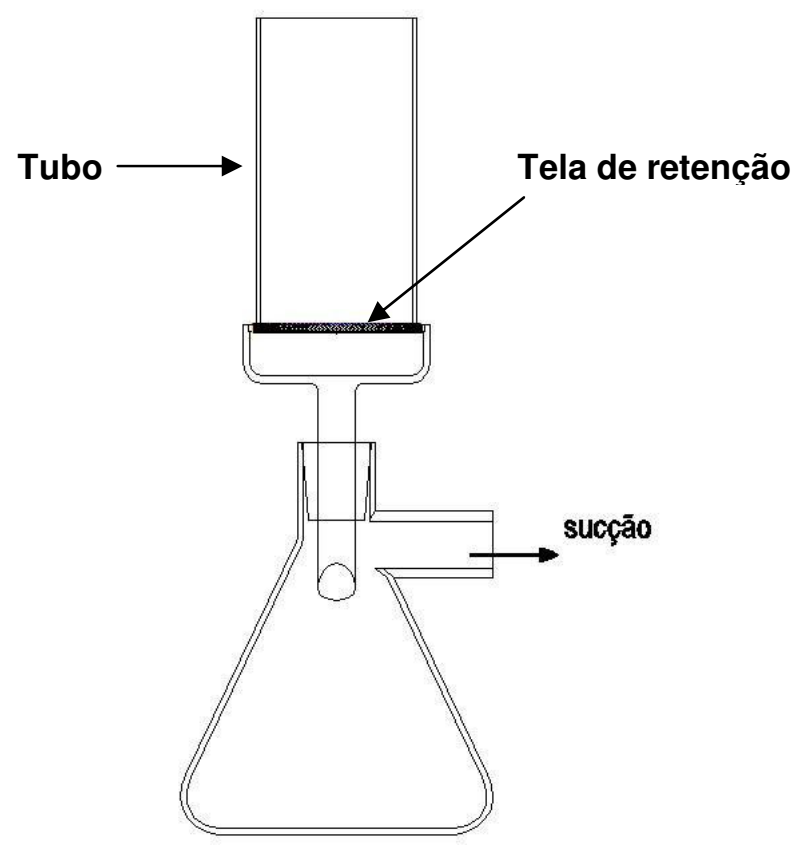

FIGURA 15: Desenho esquemático do dispositivo para secagem das sementes. 
O conjunto é formado por várias peças possibilitando a desmontagem para retirada da água e a preservação das sementes radioativas. Seus componentes estão representados na FIG. 16 e na FIG. 17.

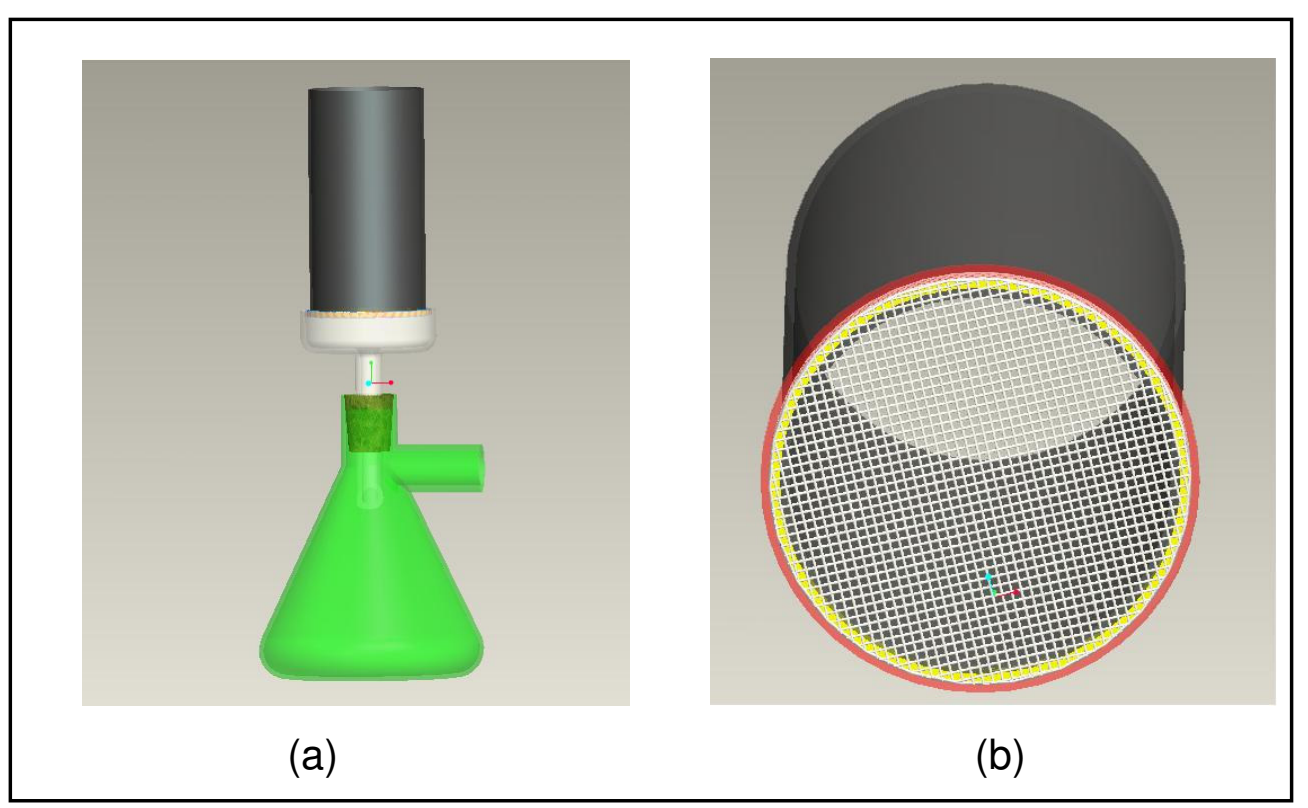

FIGURA 16: Representação do conjunto de secagem (a) e detalhe do tubo com tela de retenção (b).

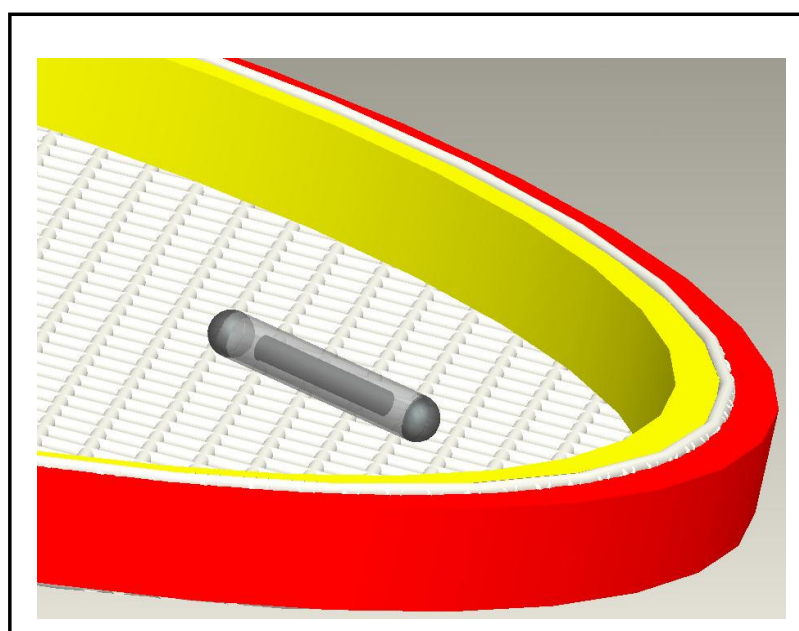

(a)

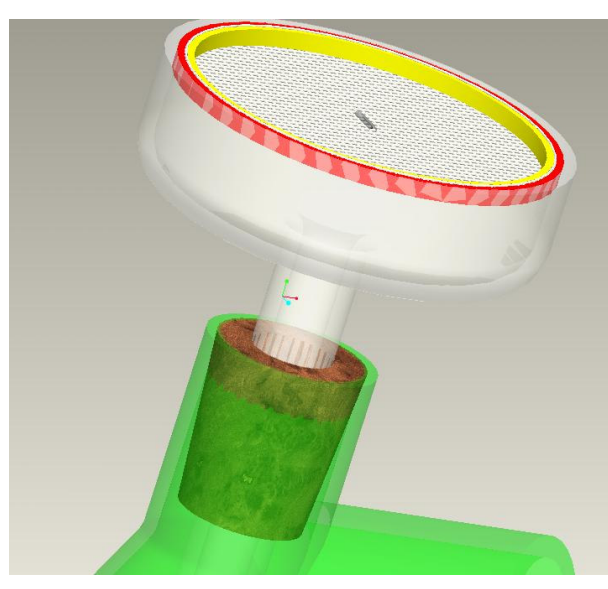

(b)

FIGURA 17: Tela de retenção (a) e sua montagem (b). 


\subsection{Resultados dos ensaios de secagem das sementes.}

A TAB. 6 mostra os resultados de secagem em função do tempo obtidos com sistema de sucção com bomba de vácuo. A TAB. 7 mostra os resultados de secagem em função do tempo obtidos com sistema de sucção com aspirador de pó doméstico.

TABELA 6: Resultados de secagem obtidos com bomba de vácuo.

\begin{tabular}{|c|c|c|c|c|}
\hline Tempo de secagem & Teste no 1 & Teste no 2 & Teste no 3 & Teste no 4 \\
\hline 10 minutos & não secaram & não secaram & não secaram & não secaram \\
\hline 15 minutos & não secaram & não secaram & não secaram & não secaram \\
\hline 15 minutos & não secaram & não secaram & não secaram & não secaram \\
\hline 20 minutos & não secaram & * secaram & *secaram & não secaram \\
\hline 30 minutos & secaram & secaram & secaram & secaram \\
\hline
\end{tabular}

* As sementes estavam secas, porém restaram gotas de água nas paredes do suporte, podendo umedecer novamente as sementes.

TABELA 7: Resultados de secagem obtidos com aspirador de pó.

\begin{tabular}{ccccc}
\hline Tempo de secagem & Teste $n^{\circ} 1$ & Teste $n^{\circ} 2$ & Teste $n^{\circ} 3$ & Teste $n^{\circ} 4$ \\
30 segundos & não secaram & não secaram & não secaram & não secaram \\
60 segundos & secaram & secaram & secaram & secaram \\
90 segundos & secaram & secaram & secaram & secaram \\
120 segundos & secaram & secaram & secaram & secaram \\
\hline
\end{tabular}

Os resultados obtidos com o aspirador de pó doméstico foram bastante satisfatórios, proporcionando uma secagem eficiente em pouco tempo, contribuindo para agilizar o processo. Além disso, o custo do equipamento é baixo e é de fácil aquisição e reposição.

\subsection{Resultados do ensaio de descontaminação de lote de sementes}

Os resultados da limpeza utilizando-se água destilada e aplicação de ultra-som são mostrados na TAB. 8 e na FIG. 18 . 
TABELA 8: Resultados da descontaminação de lote de sementes utilizando água destilada e ultra-som.

\begin{tabular}{cc}
\hline Lavagem $\mathbf{n}^{\circ}$ & Atividade $(\mathrm{Bq})$ \\
1 & 68635 \\
2 & 1332 \\
3 & 645,8 \\
4 & 241,7 \\
5 & 137,8 \\
\hline
\end{tabular}

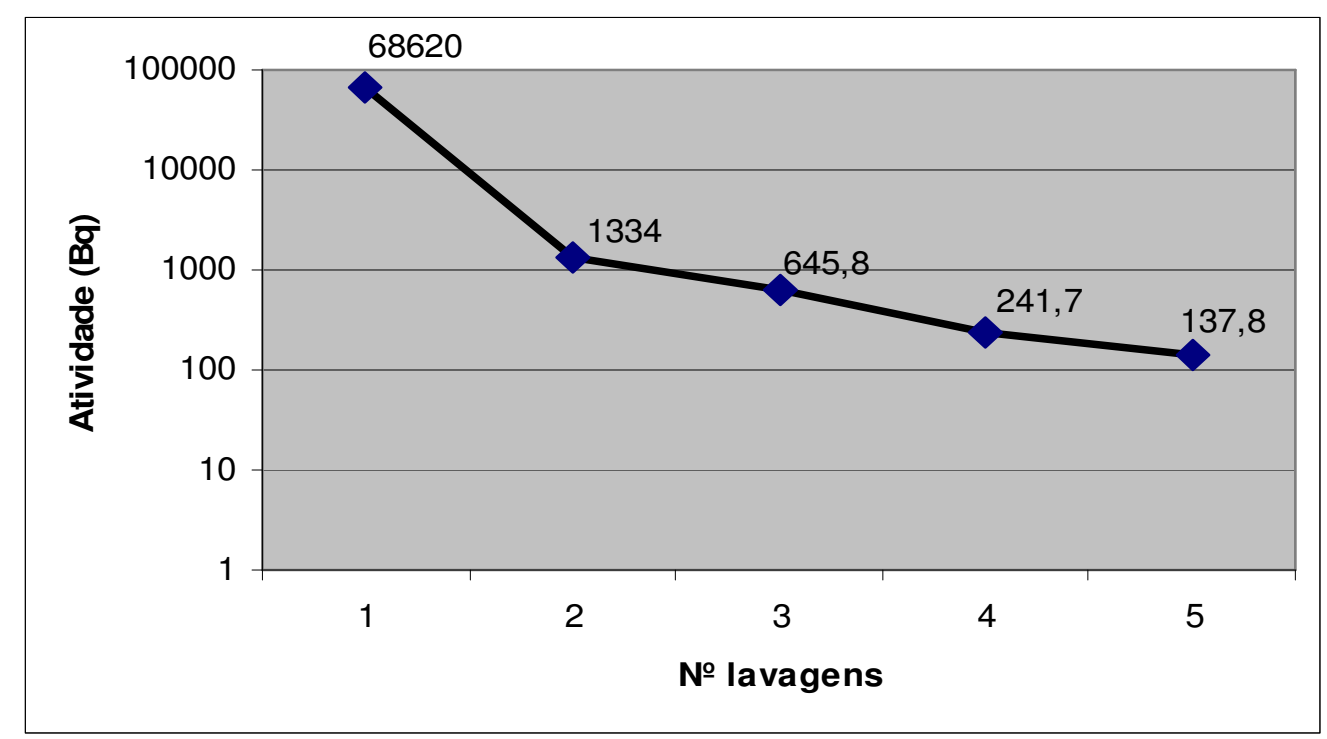

FIGURA 18: Resultados da descontaminação de lote de sementes utilizando água destilada e ultra-som.

O ensaio com acréscimo de $150 \mu \mathrm{L}$ de detergente Extran $10 \%$ foi repetido por duas vezes. Os valores de atividade após cada ciclo de limpeza são mostrados na TAB. 9 e na FIG. 19. Utilizou-se água destilada com acréscimo de detergente e aplicação de ultra-som.

TABELA 9: Resultados da descontaminação de lote de semente utilizando água destilada com detergente e aplicação de ultra-som.

\begin{tabular}{|c|c|c|c|}
\hline Ensaio no 1 & Atividade (Bq) & Ensaio no 2 & Atividade (Bq) \\
\hline Lavagem $n^{\circ} 1$ & 23590 & Lavagem $n^{\circ}$ & $\mathrm{OL}^{*}$ \\
\hline Lavagem $n \cong 2$ & 527,6 & Lavagem nœ2 & 2645,5 \\
\hline Lavagem n³ & 112,9 & Lavagem n`3 & 85,1 \\
\hline
\end{tabular}

* Fundo de escala do medidor ultrapassado 


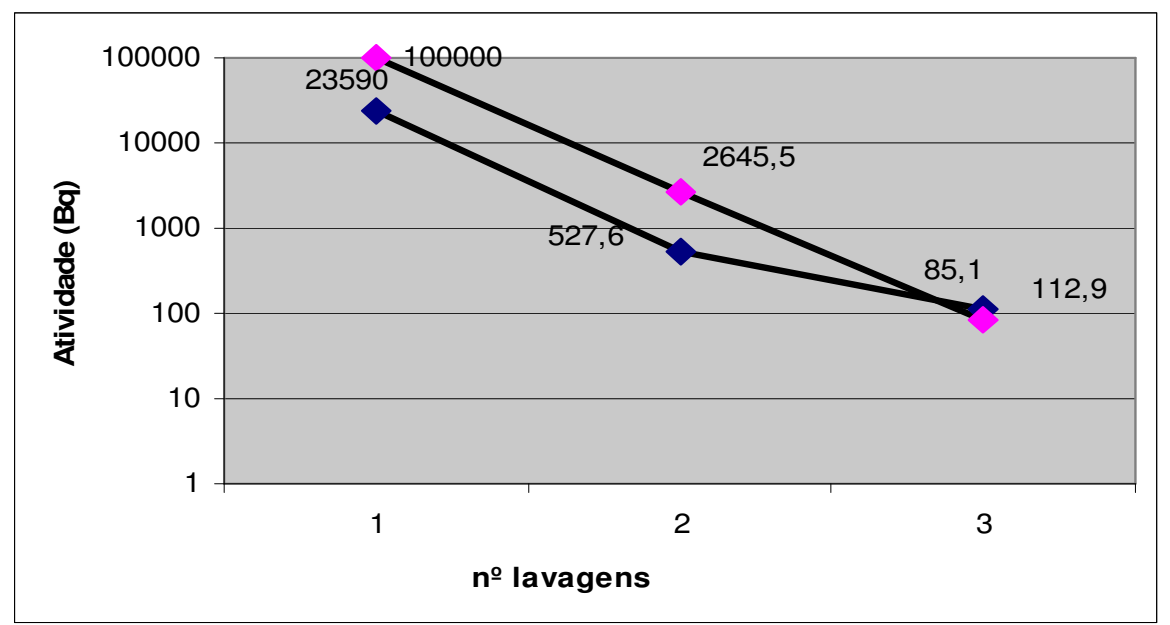

FIGURA 19: Resultados da descontaminação de lote de sementes utilizando água destilada com detergente e ultra-som.

Os resultados com nova alteração de parâmetro, utilizando lodo-131 depois de decorrida a primeira meia vida, limpeza das sementes com água destilada e aplicação de ultra-som são mostrados na TAB. 10 e na FIG. 20. O ensaio foi repetido duas vezes.

TABELA 10: Resultados da descontaminação de lote de sementes após meia vida do iodo -131 utilizando água destilada e aplicação de ultra-som.

\begin{tabular}{|c|c|c|c|}
\hline Ensaio no 1 & Atividade (Bq) & Ensaio no 2 & Atividade (Bq) \\
\hline Lavagem n ${ }^{\circ 1}$ & 24272 & Lavagem $n^{\circ 1}$ & 3540,9 \\
\hline Lavagem $n ²$ & 1480 & Lavagem $n ²$ & 67,3 \\
\hline Lavagem $n ³$ & 99,9 & Lavagem $n ` 3$ & - \\
\hline
\end{tabular}

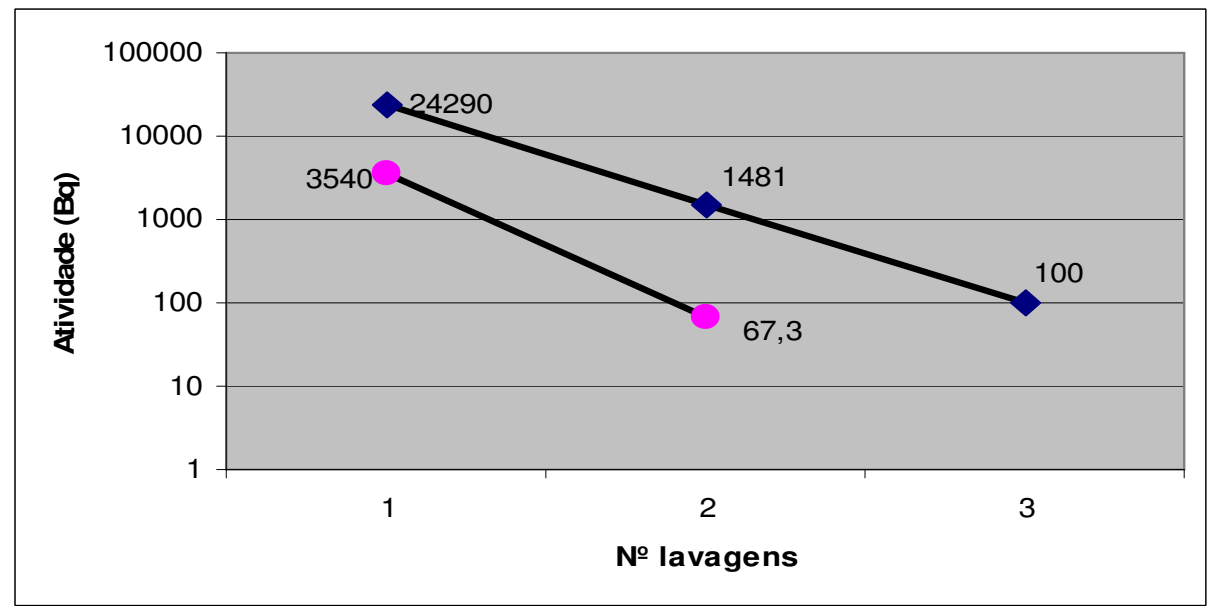

FIGURA 20: Resultados da descontaminação de lote de sementes decorrida uma meia vida do iodo -131utilizando água destilada e aplicação de ultra-som. 
Os resultados demonstraram que são necessárias pelo menos três lavagens consecutivas com adição de detergente ou cinco lavagens consecutivas sem detergente, para que seja removida uma possível contaminação superficial nas sementes. Esses ensaios simularam a situação onde praticamente todo o conteúdo de material radioativo da semente vazou para o líquido (1mCi). Caso o vazamento transfira para o líquido a metade do material radioativo da semente (experimento utilizando lodo-131 decorrida a primeira meia vida), três lavagens seriam suficientes para remoção satisfatória.

\subsection{Resultados dos ensaios de transferência de líquidos e descontaminação da tubulação}

No ensaio $\mathrm{n}{ }^{\circ}$, após a contaminação da mangueira de silicone, foram transferidas 30 alíquotas de $2 \mathrm{ml}$ de água destilada e a atividade da água foi medida em cada uma delas. Foram feitas duas séries de medidas. Após a lavagem com 30 alíquotas os valores de atividade estabilizaram em patamares inferiores a $185 \mathrm{~Bq}$ que é o valor limite estabelecido pela norma ISO $9978^{20}$ como ausência de vazamento nas fontes seladas. A TAB. 11 e a FIG. 21 mostram os resultados obtidos. 
TABELA 11: Resultados do ensaio nํ 1 - descontaminação de mangueira de silicone.

\begin{tabular}{|c|c|c|c|}
\hline $\begin{array}{c}\text { Primeira série } \\
\text { Lavagem no }\end{array}$ & Atividade (Bq) & $\begin{array}{c}\text { Segunda série } \\
\text { Lavagem no }\end{array}$ & Atividade (Bq) \\
\hline 1 & 42920 & 1 & 20313 \\
\hline 2 & 702,63 & 2 & 1152,55 \\
\hline 3 & 419,21 & 3 & 624,93 \\
\hline 4 & 310,06 & 4 & 404,78 \\
\hline 5 & 247,9 & 5 & 260,48 \\
\hline 6 & 213,12 & 6 & 210,16 \\
\hline 7 & 170,57 & 7 & 196,47 \\
\hline 8 & 156,88 & 8 & 179,45 \\
\hline 9 & 136,16 & 9 & 154,66 \\
\hline 10 & 112,85 & 10 & 127,65 \\
\hline 11 & 110,26 & 11 & 122,47 \\
\hline 12 & 122,84 & 12 & 114,7 \\
\hline 13 & 106,56 & 13 & 106,56 \\
\hline 14 & 105,45 & 14 & 95,46 \\
\hline 15 & 92,13 & 15 & 112,85 \\
\hline 16 & 95,46 & 16 & 74,37 \\
\hline 17 & 82,14 & 17 & 111,74 \\
\hline 18 & 74,37 & 18 & 75,11 \\
\hline 19 & 75,48 & 19 & 68,08 \\
\hline 20 & 73,63 & 20 & 37 \\
\hline 21 & 83,62 & 21 & 86,95 \\
\hline 22 & 75,11 & 22 & 66,6 \\
\hline 23 & 74,37 & 23 & 102,49 \\
\hline 24 & 72,52 & 24 & 128,76 \\
\hline 25 & 64,01 & 25 & 111 \\
\hline 26 & 68,08 & 26 & 66,6 \\
\hline 27 & 62,53 & 27 & 63,27 \\
\hline 28 & 64,38 & 28 & 73,26 \\
\hline 29 & 63,27 & 29 & 79,55 \\
\hline 30 & 62,9 & 30 & 67,71 \\
\hline
\end{tabular}

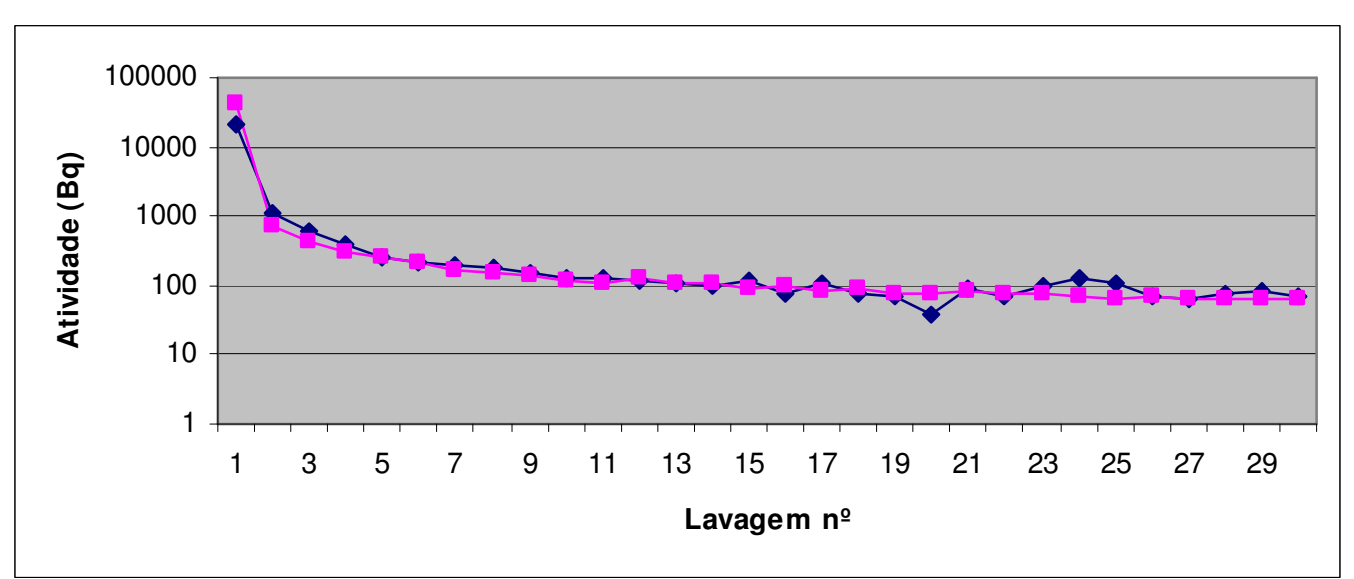

FIGURA 21: Resultados do ensaio no 1 - descontaminação de mangueira de silicone. 
Apesar da atividade medida no líquido ter diminuído para valores abaixo de $5 \mathrm{nCi}(185 \mathrm{~Bq})$, a atividade remanescente pode interferir nos resultados obtidos durante o processo de controle de qualidade das sementes. Portanto esse método de lavagem não é satisfatório para utilização prática.

No ensaio $n ²$, após a contaminação da mangueira de silicone, foram transferidos $50 \mathrm{ml}$ de água destilada para limpeza da mangueira. Na seqüência, foi transferida uma alíquota de $2 \mathrm{ml}$ de água destilada e a atividade da água foi medida. Foram realizadas duas séries de 15 repetições. Os resultados obtidos são mostrados na TAB. 12 e na FIG. 22.

TABELA 12: Resultados do ensaio ํㅜ 2 - descontaminação de mangueira de silicone.

\begin{tabular}{cccc}
\hline $\begin{array}{c}\text { Primeira série } \\
\text { Lavagem } \mathbf{n}^{\mathbf{0}}\end{array}$ & Atividade $\mathbf{( B q )}$ & $\begin{array}{c}\text { Segunda série } \\
\text { Lavagem } \mathbf{n}^{\mathbf{0}}\end{array}$ & $\begin{array}{c}\text { Atividade } \\
\mathbf{( B q})\end{array}$ \\
1 & 53,28 & 1 & 244,2 \\
2 & 103,6 & 2 & 161,69 \\
3 & 71,41 & 3 & 162,8 \\
4 & 58,83 & 4 & 160,21 \\
5 & 49,58 & 5 & 120,99 \\
6 & 49,95 & 6 & 312,28 \\
7 & 86,95 & 7 & 135,42 \\
8 & 115,81 & 8 & 155,77 \\
9 & 18,87 & 9 & 206,83 \\
10 & 100,64 & 10 & 150,22 \\
11 & 155,77 & 11 & 166,87 \\
12 & 120,99 & 12 & 134,68 \\
13 & 220,15 & 13 & 106,93 \\
14 & 206,83 & 14 & 85,1 \\
15 & 157,25 & 15 & 115,07 \\
\hline
\end{tabular}

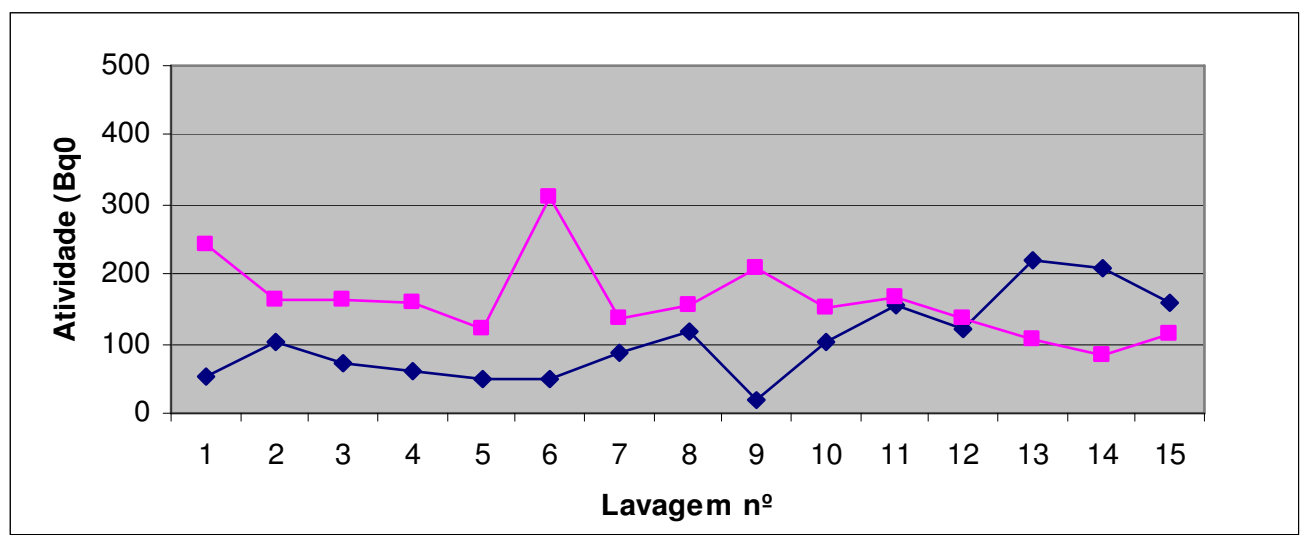

FIGURA 22: Resultados do ensaio nํ 2 - descontaminação de mangueira de silicone. 
Os resultados não são satisfatórios, pois além de valores elevados de atividade remanescente, estes apresentaram grande variação.

No ensaio $\mathrm{n}^{\circ} 3$ foi realizado o mesmo procedimento do ensaio $\mathrm{n} \circ 2$, porém com maior velocidade do líquido $(9 \mathrm{ml} /$ minuto). Os resultados são mostrados na TAB. 13 e na FIG. 23.

TABELA 13: Resultados do ensaio $n^{\circ} 3$ - descontaminação de mangueira de silicone.

\begin{tabular}{cc}
\hline Lavagem $\mathbf{n}^{\mathbf{0}}$ & Atividade $\mathbf{( B q )}$ \\
1 & 66,23 \\
2 & 58,46 \\
3 & 54,02 \\
4 & 41,81 \\
5 & 38,48 \\
6 & 34,04 \\
7 & 32,56 \\
8 & 31,45 \\
9 & 39,96 \\
10 & 29,97 \\
\hline
\end{tabular}

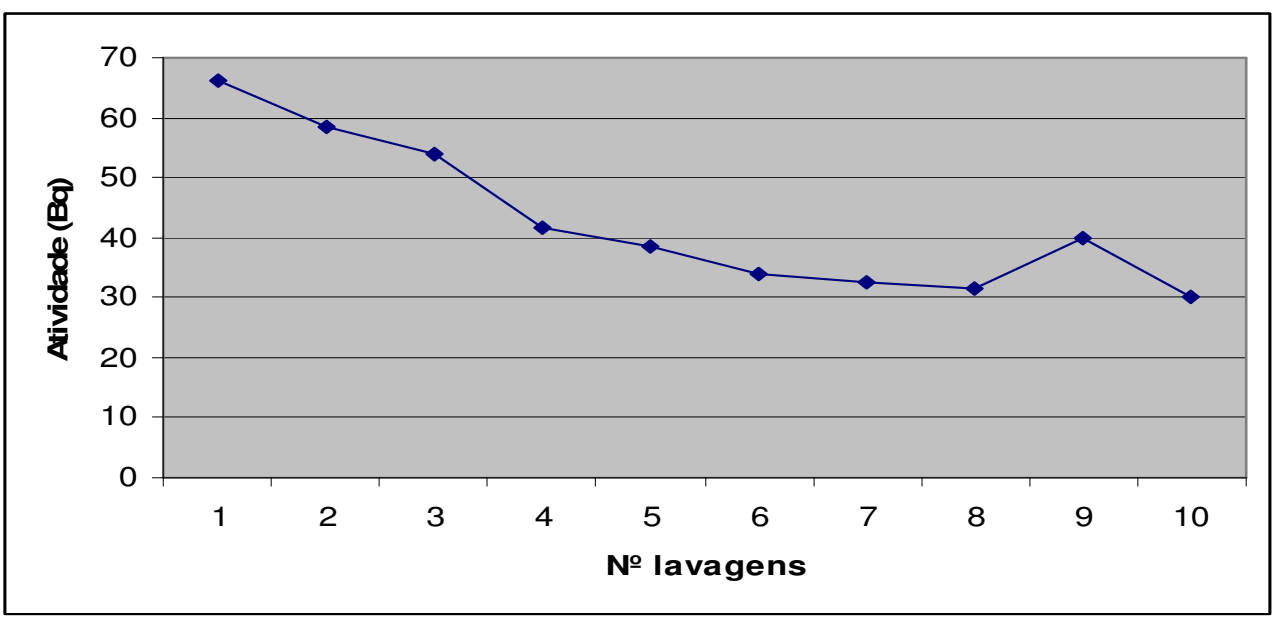

FIGURA 23: Resultados do ensaio no 3 - descontaminação de mangueira de silicone.

Com o aumento da velocidade da água na lavagem houve uma melhora (diminuição) da atividade remanescente, porém a grande variação nos resultados não foi satisfatória. 
No ensaio $\mathrm{n}^{\circ} 4$ o volume de água destilada usada na lavagem foi aumentado para $75 \mathrm{ml}$. Os resultados são mostrados na TAB. 14 e na FIG. 24.

TABELA 14: Resultados do ensaio no 4 - descontaminação de mangueira de silicone.

\begin{tabular}{cccccc}
\hline $\begin{array}{c}\text { Primeira série } \\
\text { Lavagem } \mathbf{n}-\end{array}$ & $\begin{array}{c}\text { Atividade } \\
\mathbf{( B q})\end{array}$ & $\begin{array}{c}\text { Segunda série } \\
\text { Lavagem } \mathbf{n}^{-}\end{array}$ & $\begin{array}{c}\text { Atividade } \\
\mathbf{( B q})\end{array}$ & $\begin{array}{c}\text { Terceira série } \\
\text { Lavagem } \mathbf{n}\end{array}$ & $\begin{array}{c}\text { Atividade } \\
\mathbf{( B q})\end{array}$ \\
1 & 22,94 & 1 & 13,32 & 1 & 29,80 \\
2 & 22,94 & 2 & 14,06 & 2 & 25,87 \\
3 & 26,64 & 3 & 10,73 & 3 & 35,02 \\
4 & 28,49 & 4 & 6,66 & 4 & 27,20 \\
5 & 25,16 & 5 & 16,28 & 5 & 42,02 \\
6 & 23,31 & 6 & 22,94 & 6 & 52,62 \\
7 & 25,53 & 7 & 19,61 & 7 & 60,62 \\
8 & 19,24 & 8 & 11,47 & 8 & 70,98 \\
9 & 29,23 & 9 & 12,95 & 9 & 95,65 \\
10 & 21,46 & 10 & 15,17 & 10 & 114,95 \\
\hline
\end{tabular}

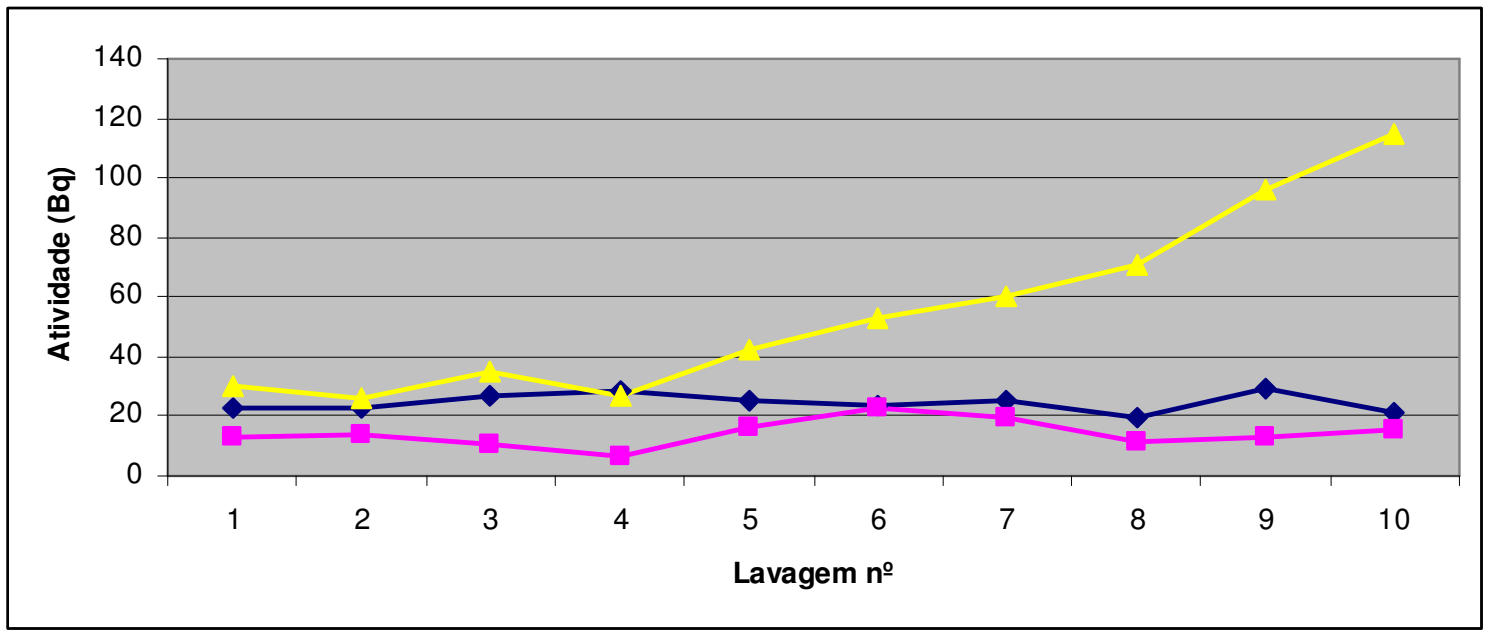

FIGURA 24: Resultados do ensaio n4 - descontaminação de mangueira de silicone.

Os resultados das duas primeiras séries (linhas azul e lilás na FIG. 24) seriam satisfatórios para utilização prática, uma vez que a atividade remanescente no líquido está bem abaixo do limite estipulado pela norma ISO $9978^{20}$ (cerca de 10\% deste) e se manteve bastante estável. Porém a última série (linha amarela na FIG. 24) demonstra um aumento na atividade medida no líquido até valores elevados quando comparados aos resultados anteriores. Esse fato foi devido à impregnação da mangueira de silicone com o iodo-131 e posterior 
contaminação da água durante as lavagens. Foram feitas várias tentativas de limpeza da mangueira transferindo grandes volumes de água destilada (total de $500 \mathrm{ml}$ ). Os valores de atividade residual não sofreram alteração significativa.

No ensaio $n 5$ o volume de água destilada usada na lavagem foi de 75 ml. A mangueira utilizada para transferência de líquidos é construída em PTFE. Foi realizada uma série de 90 ciclos de contaminação e descontaminação consecutivos. Os resultados são mostrados na TAB. 15 e na FIG. 25.

TABELA 15: Resultados do ensaio no 5 - descontaminação de mangueira de PTFE.

\begin{tabular}{|c|c|c|c|c|c|}
\hline Ciclo no & Atividade (Bq) & Ciclo no & Atividade (Bq) & Ciclo no & Atividade (Bq) \\
\hline 1 & 6,29 & 31 & 4,44 & 61 & 6,29 \\
\hline 2 & 4,44 & 32 & 2,59 & 62 & 4,44 \\
\hline 3 & 14,8 & 33 & 3,33 & 63 & 14,8 \\
\hline 4 & 7,03 & 34 & 5,55 & 64 & 7,03 \\
\hline 5 & 11,1 & 35 & 3,33 & 65 & 11,1 \\
\hline 6 & 17,02 & 36 & 5,18 & 66 & 17,02 \\
\hline 7 & 4,44 & 37 & 5,55 & 67 & 4,44 \\
\hline 8 & 5,92 & 38 & 4,81 & 68 & 5,92 \\
\hline 9 & 4,44 & 39 & 5,55 & 69 & 4,44 \\
\hline 10 & 2,96 & 40 & 6,29 & 70 & 2,96 \\
\hline 11 & 3,33 & 41 & 9,25 & 71 & 3,33 \\
\hline 12 & 1,85 & 42 & 3,33 & 72 & 1,85 \\
\hline 13 & 1,85 & 43 & 4,81 & 73 & 1,85 \\
\hline 14 & 4,07 & 44 & 3,7 & 74 & 4,07 \\
\hline 15 & 3,7 & 45 & 3,33 & 75 & 3,7 \\
\hline 16 & 1,85 & 46 & 9,25 & 76 & 1,85 \\
\hline 17 & 7,4 & 47 & 5,18 & 77 & 7,4 \\
\hline 18 & 2,22 & 48 & 7,77 & 78 & 2,22 \\
\hline 19 & 4,44 & 49 & 8,51 & 79 & 4,44 \\
\hline 20 & 2,59 & 50 & 4,44 & 80 & 2,59 \\
\hline 21 & 1,85 & 51 & 5,55 & 81 & 1,85 \\
\hline 22 & 3,33 & 52 & 5,18 & 82 & 3,33 \\
\hline 23 & 7,03 & 53 & 6,29 & 83 & 7,03 \\
\hline 24 & 2,59 & 54 & 8,88 & 84 & 2,59 \\
\hline 25 & 2,59 & 55 & 4,44 & 85 & 2,59 \\
\hline 26 & 4,44 & 56 & 5,92 & 86 & 4,44 \\
\hline 27 & 2,59 & 57 & 4,44 & 87 & 2,59 \\
\hline 28 & 14,43 & 58 & 2,96 & 88 & 14,43 \\
\hline 29 & 15,91 & 59 & 3,33 & 89 & 15,91 \\
\hline 30 & 20,35 & 60 & 1,85 & 90 & 20,35 \\
\hline
\end{tabular}




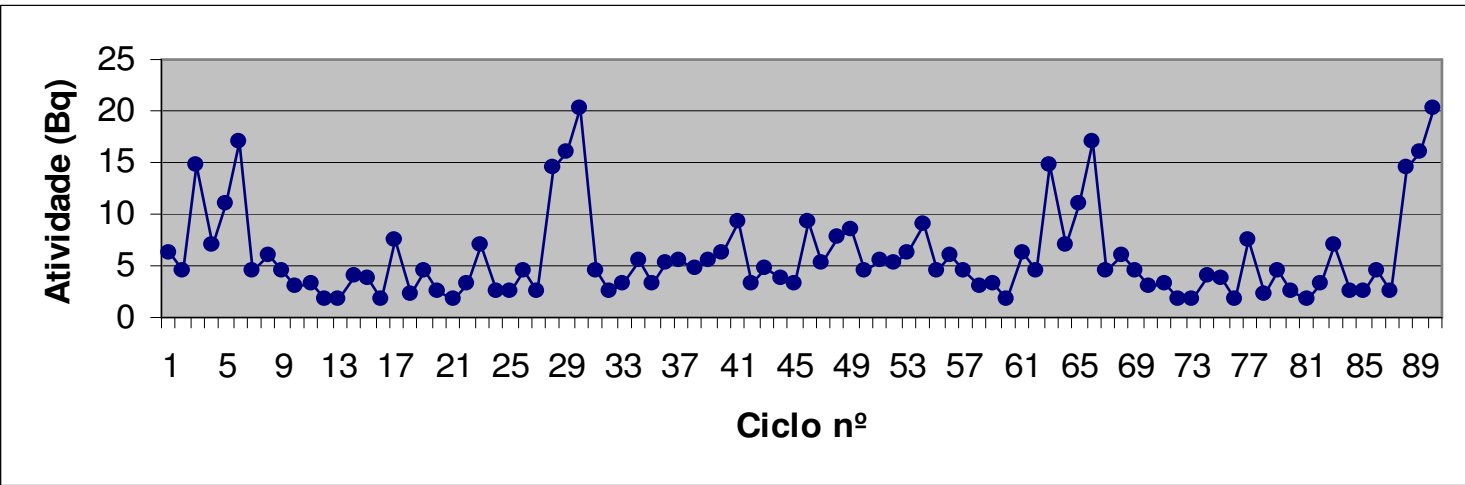

FIGURA 25: Resultados do ensaio no 5 - descontaminação de mangueira de PTFE.

Os resultados deste ensaio foram satisfatórios tendo em vista sua utilização prática. Os valores de atividade remanescente no líquido ficaram bem abaixo do limite estipulado pela norma ISO $9978^{20}$ (no máximo cerca de 10\% deste valor) e se mantiveram dentro desse limite mesmo após os 90 ciclos de contaminação e descontaminação executados. A diminuição do diâmetro interno da mangueira e o aumento da velocidade de transferência contribuíram para maior eficiência no arraste dos contaminantes presentes na superfície interna da mangueira. A partir dos resultados foram definidos os parâmetros para descontaminação de tubulações:

- As mangueiras de transporte de líquidos deverão ser de PTFE com diâmetro interno de $1 \mathrm{~mm}$.

- A vazão para limpeza efetiva da mangueira de PTFE com diâmetro interno de $1 \mathrm{~mm}$ deverá ser de $45 \mathrm{ml} /$ minuto.

- O volume de água destilada utilizado para limpeza da tubulação deverá ser no mínimo $75 \mathrm{ml}$.

\subsection{Resultados da variação de parâmetros nos métodos recomendados}

O corte das sementes de iodo-125 com alicate propiciou o vazamento de material radioativo do interior da semente. A FIG. 26 mostra uma semente de iodo125 cortada, em imagem ampliada. 


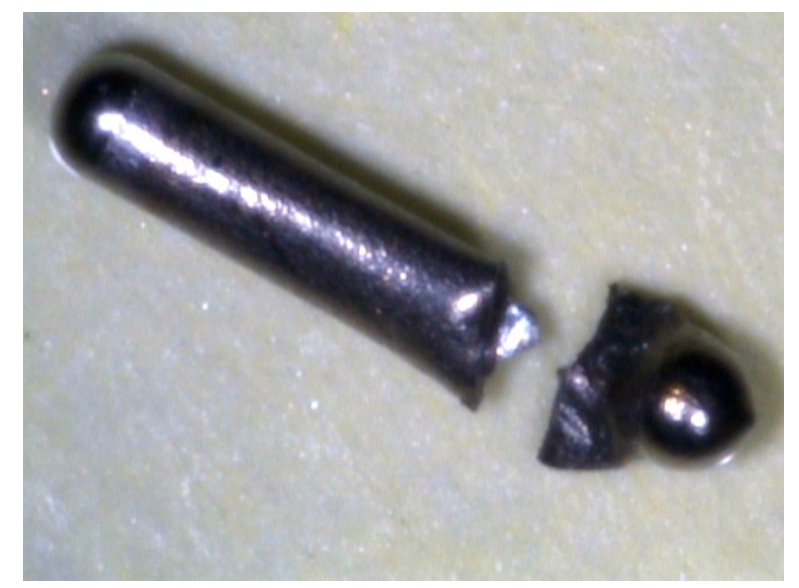

FIGURA 26: Semente de iodo-125 cortada com alicate.

A imagem da semente cortada mostra que ocorreu amassamento da fina parede de titânio antes da ruptura. Devido às características mecânicas da cápsula de titânio é difícil danificar o invólucro da semente, mesmo utilizando uma ferramenta de corte. Os valores de atividade medidos nas duas sementes antes do corte foram: semente ํㅜㄹ atividade de 1,68 kBq e a semente $\mathrm{n}^{\circ} 2$ atividade de 1,66 $\mathrm{kBq}$. A TAB. 16 mostra os resultados obtidos com as variações realizadas nos métodos de ensaio de estanqueidade com temperatura de $20^{\circ} \mathrm{C}$ e $50^{\circ} \mathrm{C}$.

TABELA 16: Resultados obtidos com as variações nos ensaios de estanqueidade.

\begin{tabular}{|c|c|c|c|c|}
\hline & $\begin{array}{c}\text { Semente no } 1 \\
\text { Ensaios a } 20^{\circ} \mathrm{C}\end{array}$ & $\begin{array}{l}\text { Atividade } \\
\text { medida } \\
(\mathrm{Bq})\end{array}$ & $\begin{array}{c}\text { Semente } n^{\circ} 2 \\
\text { Ensaios a } 50^{\circ} \mathrm{C}\end{array}$ & $\begin{array}{l}\text { Atividade } \\
\text { medida } \\
(\mathrm{Bq})\end{array}$ \\
\hline $\begin{array}{l}\text { Conforme } \\
\text { a norma }\end{array}$ & $\begin{array}{l}\text { Imersão por } 24 \text { horas em água } \\
\text { destilada }(2 \mathrm{ml}) \text { em temperatura } \\
\text { ambiente }\left(20^{\circ} \mathrm{C} \pm 5^{\circ} \mathrm{C}\right)\end{array}$ & 3,52 & $\begin{array}{c}\text { Imersão por } 4 \text { horas em água } \\
\text { destilada }(2 \mathrm{ml}) \text { em } \\
\text { temperatura de } 50^{\circ} \mathrm{C}\end{array}$ & 3,18 \\
\hline $\begin{array}{c}\text { Variação } \\
n^{\circ} 1\end{array}$ & $\begin{array}{l}\text { Imersão por } 24 \text { horas em água } \\
\text { destilada }(2 \mathrm{ml})+150 \text { ul } \\
\text { detergente em temperatura } \\
\text { ambiente }\left(20^{\circ} \mathrm{C} \pm 5^{\circ} \mathrm{C}\right)\end{array}$ & 22,07 & $\begin{array}{l}\text { Imersão por } 4 \text { horas em água } \\
\text { destilada }(2 \mathrm{ml})+150 \text { ul } \\
\text { detergente em temperatura } \\
\text { de } 50^{\circ} \mathrm{C}\end{array}$ & 38,56 \\
\hline $\begin{array}{c}\text { Variação } \\
n{ }^{\circ} 2\end{array}$ & $\begin{array}{l}\text { Imersão por } 24 \text { horas em água } \\
\text { destilada }(2 \mathrm{ml})+150 \text { ul } \mathrm{HClO}_{4} \\
(\mathrm{pH}=1,5) \text { à temperatura } \\
\text { ambiente }\left(20^{\circ} \mathrm{C} \pm 5^{\circ} \mathrm{C}\right)\end{array}$ & 21,59 & $\begin{array}{l}\text { Imersão por } 4 \text { horas em água } \\
\text { destilada }(2 \mathrm{ml})+150 \text { ul } \mathrm{HClO}_{4} \\
(\mathrm{pH}=1,5) \text { à temperatura de } \\
50^{\circ} \mathrm{C} \pm 5^{\circ} \mathrm{C} \text {. }\end{array}$ & 5,30 \\
\hline $\begin{array}{l}\text { Variação } \\
n^{\circ} 3 \\
\text { (excedeu } \\
\text { a norma) }\end{array}$ & $\begin{array}{l}\text { Imersão por } 24 \text { horas em água } \\
\text { destilada }(2 \mathrm{ml}), 10 \mathrm{~min} \text {. ultra- } \\
\text { som, temperatura ambiente } \\
\left(20^{\circ} \mathrm{C} \pm 5^{\circ} \mathrm{C}\right)\end{array}$ & 269,63 & $\begin{array}{c}\text { Imersão por } 4 \text { horas em água } \\
\text { destilada }(2 \mathrm{ml}), 30 \mathrm{~min} \text {. ultra- } \\
\text { som, temperatura } \\
\text { de } 50^{\circ} \mathrm{C}\end{array}$ & 82,77 \\
\hline
\end{tabular}


Após a adição de detergente ao líquido de imersão (variação $\mathrm{n}^{\circ} 1$ ), os valores de atividade detectados aumentaram de 3,52 Bq para 22,07 Bq (cerca de 6 vezes) no ensaio a $20^{\circ} \mathrm{C}$ e de $3,18 \mathrm{~Bq}$ para $38,56 \mathrm{~Bq}$ (cerca de 12 vezes) no ensaio a $50^{\circ} \mathrm{C}$. A adição de ácido (variação $\mathrm{n}{ }^{\circ}$ ) provocou aumento na atividade detectada de cerca de 6 vezes no ensaio a $20^{\circ} \mathrm{C}$, e de 1,7 vezes no ensaio a $50^{\circ} \mathrm{C}$.

A aplicação de ultra-som durante a imersão resultou em um aumento muito maior nos valores de atividade obtidos. No ensaio a $20^{\circ} \mathrm{C}$, o valor aumentou de $3,52 \mathrm{~Bq}$ para $269,63 \mathrm{~Bq}$ (cerca de 76 vezes). No ensaio a $50^{\circ} \mathrm{C}$ aumentou de $3,18 \mathrm{~Bq}$ para 82,77 Bq (cerca de 26 vezes).

Os resultados mostraram a vantagem da aplicação de ultra-som durante os ensaios por imersão realizados a $20^{\circ} \mathrm{C}$ e $50^{\circ} \mathrm{C}$, aumentando a sensibilidade na detecção de vazamentos. A utilização concomitante de ultra-som durante o período de imersão das sementes excedeu as exigências da norma ISO $9978^{20}$ para esses métodos de ensaio e mostrou-se de grande valia para se detectar vazamentos nas sementes. A adição de produtos químicos na água de imersão aumenta a complexidade dos procedimentos, exige maior número de recipientes e necessita a posterior retirada dos seus resíduos, implicando lavagens posteriores ao ensaio, mesmo na ausência de vazamento nas sementes. Por esses motivos decidiu-se pela não utilização desses produtos.

\subsection{Resultados das medidas de atividade das sementes}

O valor de atividade de cada semente utilizada nos ensaios foi medido antes de se efetuar o corte. Os valores obtidos estão listados na TAB. 17 sendo as medidas realizadas em 26 de novembro de 2008. Esses valores foram utilizados para calcular o ajuste necessário dos resultados devido ao decaimento do radioisótopo, uma vez que os ensaios foram realizados em datas diferentes após essa medição. 
TABELA 17: Valores de atividade das sementes.

\begin{tabular}{cccccccc}
\hline $\begin{array}{c}\text { Semente } \\
\text { no }\end{array}$ & $\begin{array}{c}\text { Atividade } \\
\text { (MBq) }\end{array}$ & $\begin{array}{c}\text { Semente } \\
\mathbf{n}^{\mathbf{0}}\end{array}$ & $\begin{array}{c}\text { Atividade } \\
\text { (MBq) }\end{array}$ & $\begin{array}{c}\text { Semente } \\
\mathbf{n}^{\mathbf{M}}\end{array}$ & $\begin{array}{c}\text { Atividade } \\
\text { (MBq) }\end{array}$ & $\begin{array}{c}\text { Semente } \\
\mathbf{n}^{\mathbf{0}}\end{array}$ & $\begin{array}{c}\text { Atividade } \\
\text { (MBq) }\end{array}$ \\
$\mathbf{1}$ & 38,11 & $\mathbf{2 6}$ & 37,74 & $\mathbf{5 1}$ & 37,74 & $\mathbf{7 6}$ & 38,11 \\
$\mathbf{2}$ & 38,11 & $\mathbf{2 7}$ & 37,74 & $\mathbf{5 2}$ & 37,74 & $\mathbf{7 7}$ & 37,74 \\
$\mathbf{3}$ & 37,74 & $\mathbf{2 8}$ & 38,48 & $\mathbf{5 3}$ & 38,11 & $\mathbf{7 8}$ & 38,48 \\
$\mathbf{4}$ & 38,48 & $\mathbf{2 9}$ & 38,11 & $\mathbf{5 4}$ & 38,11 & $\mathbf{7 9}$ & 38,11 \\
$\mathbf{5}$ & 38,11 & $\mathbf{3 0}$ & 37,74 & $\mathbf{5 5}$ & 38,48 & $\mathbf{8 0}$ & 37,74 \\
$\mathbf{6}$ & 38,48 & $\mathbf{3 1}$ & 37,74 & $\mathbf{5 6}$ & 38,11 & $\mathbf{8 1}$ & 37,74 \\
$\mathbf{7}$ & 38,48 & $\mathbf{3 2}$ & 37,37 & $\mathbf{5 7}$ & 37,74 & $\mathbf{8 2}$ & 38,11 \\
$\mathbf{8}$ & 38,11 & $\mathbf{3 3}$ & 37,74 & $\mathbf{5 8}$ & 38,11 & $\mathbf{8 3}$ & 38,11 \\
$\mathbf{9}$ & 38,48 & $\mathbf{3 4}$ & 38,11 & $\mathbf{5 9}$ & 38,11 & $\mathbf{8 4}$ & 37,37 \\
$\mathbf{1 0}$ & 37,74 & $\mathbf{3 5}$ & 37,74 & $\mathbf{6 0}$ & 37,74 & $\mathbf{8 5}$ & 38,85 \\
$\mathbf{1 1}$ & 38,11 & $\mathbf{3 6}$ & 38,48 & $\mathbf{6 1}$ & 38,11 & $\mathbf{8 6}$ & 38,11 \\
$\mathbf{1 2}$ & 38,48 & $\mathbf{3 7}$ & 38,11 & $\mathbf{6 2}$ & 38,11 & $\mathbf{8 7}$ & 38,11 \\
$\mathbf{1 3}$ & 38,11 & $\mathbf{3 8}$ & 37,74 & $\mathbf{6 3}$ & 38,11 & $\mathbf{8 8}$ & 38,11 \\
$\mathbf{1 4}$ & 38,48 & $\mathbf{3 9}$ & 37,74 & $\mathbf{6 4}$ & 38,11 & $\mathbf{8 9}$ & 39,22 \\
$\mathbf{1 5}$ & 38,11 & $\mathbf{4 0}$ & 37,74 & $\mathbf{6 5}$ & 38,11 & $\mathbf{9 0}$ & 38,48 \\
$\mathbf{1 6}$ & 38,11 & $\mathbf{4 1}$ & 37,74 & $\mathbf{6 6}$ & 37,74 & $\mathbf{9 1}$ & 38,11 \\
$\mathbf{1 7}$ & 38,48 & $\mathbf{4 2}$ & 37,37 & $\mathbf{6 7}$ & 38,11 & $\mathbf{9 2}$ & 37,74 \\
$\mathbf{1 8}$ & 38,11 & $\mathbf{4 3}$ & 38,48 & $\mathbf{6 8}$ & 37,74 & $\mathbf{9 3}$ & 39,22 \\
$\mathbf{1 9}$ & 38,48 & $\mathbf{4 4}$ & 37,74 & $\mathbf{6 9}$ & 37,74 & $\mathbf{9 4}$ & 37,74 \\
$\mathbf{2 0}$ & 38,85 & $\mathbf{4 5}$ & 37,74 & $\mathbf{7 0}$ & 37,74 & $\mathbf{9 5}$ & 38,85 \\
$\mathbf{2 1}$ & 37,37 & $\mathbf{4 6}$ & 38,85 & $\mathbf{7 1}$ & 38,11 & $\mathbf{9 6}$ & 38,11 \\
$\mathbf{2 2}$ & 38,11 & $\mathbf{4 7}$ & 37,74 & $\mathbf{7 2}$ & 38,11 & $\mathbf{9 7}$ & 38,48 \\
$\mathbf{2 3}$ & 37,74 & $\mathbf{4 8}$ & 37,74 & $\mathbf{7 3}$ & 38,11 & $\mathbf{9 8}$ & 37,37 \\
$\mathbf{2 4}$ & 38,11 & $\mathbf{4 9}$ & 38,11 & $\mathbf{7 4}$ & 37,74 & $\mathbf{9 9}$ & 37,74 \\
$\mathbf{2 5}$ & 37,74 & $\mathbf{5 0}$ & 38,11 & $\mathbf{7 5}$ & 37,74 & $\mathbf{1 0 0}$ & 38,85 \\
\hline
\end{tabular}

Após as medidas de atividade, as sementes foram cortadas com a máquina de corte Isomet. A FIG. 27 mostra imagens de três sementes depois de submetidas ao corte. Pretendeu-se realizar cortes com o máximo de repetibilidade nas dimensões, porém existiu uma variação inerente ao método utilizado.

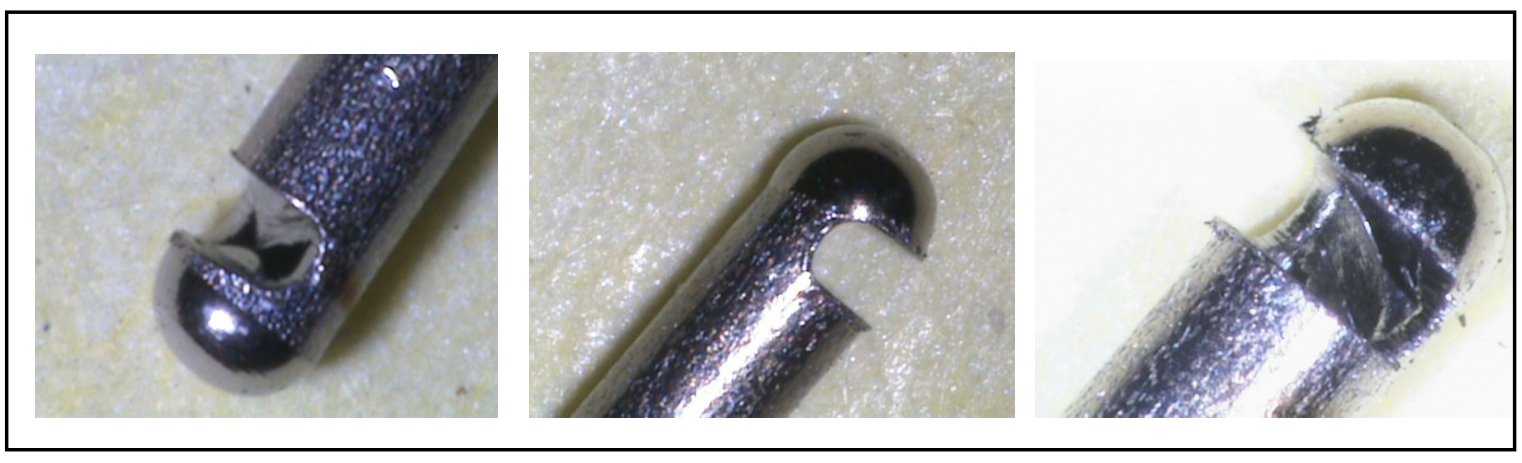

FIGURA 27: Imagens de três sementes submetidas ao corte. 


\subsection{Resultados dos ensaios de estanqueidade}

Realizaram-se os cinco tipos de ensaio de estanqueidade classificados pela norma como preferidos e os resultados obtidos foram os seguintes:

\section{- Resultados do ensaio de imersão em líquido cintilador}

A TAB. 18 apresenta os valores de atividade obtidos após o ensaio de imersão em líquido cintilador, realizados com as sementes de $\mathrm{n}^{\circ} 1$ a 20.

TABELA 18: Resultados dos ensaios de estanqueidade utilizando líquido cintilador

\begin{tabular}{cccccccc}
\hline $\begin{array}{c}\text { Semente } \\
\mathbf{n} \mathbf{0}\end{array}$ & $\begin{array}{c}\text { Atividade } \\
\mathbf{( k B q )}\end{array}$ & $\begin{array}{c}\text { Semente } \\
\mathbf{n} \mathbf{0}\end{array}$ & $\begin{array}{c}\text { Atividade } \\
\mathbf{( k B q )}\end{array}$ & $\begin{array}{c}\text { Semente } \\
\mathbf{n} \mathbf{0}\end{array}$ & $\begin{array}{c}\text { Atividade } \\
\mathbf{( k B q )}\end{array}$ & $\begin{array}{c}\text { Semente } \\
\mathbf{n} \mathbf{0}\end{array}$ & $\begin{array}{c}\text { Atividade } \\
(\mathbf{k B q})\end{array}$ \\
$\mathbf{1}$ & 0,3102 & $\mathbf{6}$ & 0,4701 & $\mathbf{1 1}$ & 0,1980 & $\mathbf{1 6}$ & 0,5256 \\
$\mathbf{2}$ & 0,3565 & $\mathbf{7}$ & 0,7120 & $\mathbf{1 2}$ & 0,3023 & $\mathbf{1 7}$ & 0,7760 \\
$\mathbf{3}$ & 0,5465 & $\mathbf{8}$ & 0,6400 & $\mathbf{1 3}$ & 0,2261 & $\mathbf{1 8}$ & 0,6787 \\
$\mathbf{4}$ & 0,2945 & $\mathbf{9}$ & 0,6819 & $\mathbf{1 4}$ & 1,0940 & $\mathbf{1 9}$ & 0,6260 \\
$\mathbf{5}$ & 0,5861 & $\mathbf{1 0}$ & 0,8006 & $\mathbf{1 5}$ & 1,5161 & $\mathbf{2 0}$ & 0,1649 \\
\hline
\end{tabular}

O valor médio de atividade obtido com imersão em cintilador líquido foi de $575,30 \mathrm{~Bq}$ e o valor mínimo foi de $164,85 \mathrm{~Bq}$. O valor médio equivale a aproximadamente 3 vezes o valor estipulado pela norma ISO $9978^{20}$ para a detecção de vazamento na fonte ensaiada (185 Bq), enquanto o valor mínimo ficou abaixo do limite. Esse valor, caso fosse obtido durante a produção das sementes, poderia indicar um falso resultado negativo para o ensaio de estanqueidade, ocasionando a aprovação e liberação da fonte para utilização, sendo que a mesma não está em conformidade com as exigências. A utilização de líquido cintilador como líquido de imersão, neste estudo, não se mostrou eficaz para detecção de vazamento nas sementes.

\section{- Resultados do ensaio de imersão em água destilada com temperatura ambiente}

Na TAB. 19 são mostrados os valores de atividade obtidos após o ensaio de imersão em água destilada em temperatura ambiente $\left(20^{\circ} \mathrm{C} \pm 5^{\circ} \mathrm{C}\right)$ durante 24 horas e aplicação de ultra-som por 10 minutos, realizados com as sementes de $\mathrm{n}^{\circ} 21$ a 40. 
TABELA 19: Resultados dos ensaios de estanqueidade em temperatura ambiente

\begin{tabular}{cccccccc}
\hline $\begin{array}{c}\text { Semente } \\
\mathbf{n} \mathbf{0}\end{array}$ & $\begin{array}{c}\text { Atividade } \\
\mathbf{( k B q )}\end{array}$ & $\begin{array}{c}\text { Semente } \\
\mathbf{n} \mathbf{0}\end{array}$ & $\begin{array}{c}\text { Atividade } \\
\mathbf{( k B q )}\end{array}$ & $\begin{array}{c}\text { Semente } \\
\mathbf{n} \mathbf{0}\end{array}$ & $\begin{array}{c}\text { Atividade } \\
\mathbf{( k B q )}\end{array}$ & $\begin{array}{c}\text { Semente } \\
\mathbf{n} \mathbf{0}\end{array}$ & $\begin{array}{c}\text { Atividade } \\
(\mathbf{k B q})\end{array}$ \\
$\mathbf{2 1}$ & 967,9 & $\mathbf{2 6}$ & 2852,0 & $\mathbf{3 1}$ & 2474,7 & $\mathbf{3 6}$ & 2731,9 \\
$\mathbf{2 2}$ & 1779,4 & $\mathbf{2 7}$ & 4225,7 & $\mathbf{3 2}$ & 1944,9 & $\mathbf{3 7}$ & 1596,0 \\
$\mathbf{2 3}$ & 3269,4 & $\mathbf{2 8}$ & 2976,1 & $\mathbf{3 3}$ & 1888,0 & $\mathbf{3 8}$ & 2486,3 \\
$\mathbf{2 4}$ & 934,3 & $\mathbf{2 9}$ & 2579,4 & $\mathbf{3 4}$ & 1660,6 & $\mathbf{3 9}$ & 1806,6 \\
$\mathbf{2 5}$ & 514,3 & $\mathbf{3 0}$ & 1860,9 & $\mathbf{3 5}$ & 1611,5 & $\mathbf{4 0}$ & 1373,7 \\
\hline
\end{tabular}

O ensaio de imersão com água a $20^{\circ} \mathrm{C}$ resultou em um valor médio de atividade de 2076,7 kBq, equivalendo a 11225 vezes o valor limite de $185 \mathrm{~Bq}$. $\mathrm{O}$ valor mínimo obtido foi de $514,3 \mathrm{kBq}$, equivalendo a 2780 vezes o valor limite.

Os resultados apontam eficácia elevada desse método de ensaio na detecção de vazamentos. Outro aspecto positivo é a simplicidade do ensaio, utilizando apenas água destilada como meio de imersão, sem a necessidade de aquecimento. Uma característica desfavorável desse método é o longo período de imersão (24 horas), podendo ser um fator limitante no processo produtivo.

\section{- Resultados do ensaio de imersão em água destilada com temperatura de 50 C}

Na TAB. 20 são apresentados os valores de atividade obtidos após o ensaio de imersão em água destilada à temperatura de $50^{\circ} \mathrm{C} \pm 5^{\circ} \mathrm{C}$ durante 4 horas, com aplicação de ultra-som por 30 minutos, realizados com as sementes de $n^{\circ} 41$ a 60.

TABELA 20: Resultados dos ensaios de estanqueidade à temperatura de $50^{\circ} \mathrm{C}$.

\begin{tabular}{cccccccc}
\hline $\begin{array}{c}\text { Semente } \\
\mathbf{n} \mathbf{0}\end{array}$ & $\begin{array}{c}\text { Atividade } \\
\mathbf{( k B q )}\end{array}$ & $\begin{array}{c}\text { Semente } \\
\mathbf{n} \mathbf{0}\end{array}$ & $\begin{array}{c}\text { Atividade } \\
\mathbf{( k B q )}\end{array}$ & $\begin{array}{c}\text { Semente } \\
\mathbf{n} \mathbf{0}\end{array}$ & $\begin{array}{c}\text { Atividade } \\
\mathbf{( k B q )}\end{array}$ & $\begin{array}{c}\text { Semente } \\
\mathbf{n} \mathbf{0}\end{array}$ & $\begin{array}{c}\text { Atividade } \\
(\mathbf{k B q})\end{array}$ \\
$\mathbf{4 1}$ & 121,2 & $\mathbf{4 6}$ & 4411,8 & $\mathbf{5 1}$ & 1417,6 & $\mathbf{5 6}$ & 219,0 \\
$\mathbf{4 2}$ & 127,5 & $\mathbf{4 7}$ & $\mathbf{0 , 0 5 8 9}$ & $\mathbf{5 2}$ & 72,0 & $\mathbf{5 7}$ & 318,0 \\
$\mathbf{4 3}$ & 639,9 & $\mathbf{4 8}$ & 1683,8 & $\mathbf{5 3}$ & 2461,8 & $\mathbf{5 8}$ & 1558,5 \\
$\mathbf{4 4}$ & 360,9 & $\mathbf{4 9}$ & 1049,3 & $\mathbf{5 4}$ & 1699,3 & $\mathbf{5 9}$ & 581,5 \\
$\mathbf{4 5}$ & 756,2 & $\mathbf{5 0}$ & 1796,2 & $\mathbf{5 5}$ & 821,9 & $\mathbf{6 0}$ & $\mathbf{0 , 0 0 4 7}$ \\
\hline
\end{tabular}

O valor médio obtido nos ensaios com água a $50^{\circ} \mathrm{C}$ foi $1116,5 \mathrm{kBq}$ e o valor mínimo $72 \mathrm{kBq}$, equivalentes a 6035 vezes o valor limite $(185 \mathrm{~Bq})$ e 390 vezes o valor limite, respectivamente. Apesar de apresentar valores não tão elevados quanto os obtidos com imersão a $20^{\circ} \mathrm{C}$, esse método também se 
mostrou eficaz na detecção de vazamentos, com uma característica favorável que é o menor tempo de imersão (4 horas).

Os valores obtidos com as sementes de $n^{\circ} 47(58,9 \mathrm{~Bq})$ e $\mathrm{n}^{\circ} 60(4,7 \mathrm{~Bq})$ indicam ausência de vazamento. A semente de $n^{\circ} 47$ sofreu apenas deformação na cápsula, sem se romper. A semente de $n^{\circ} 60$ não foi sequer arranhada. Durante a operação de corte pode ter ocorrido um desvio na posição do dispositivo de fixação das sementes sem que fosse percebido, alterando o ajuste de profundidade de corte. Esses resultados, porém, estão de acordo com as condições das respectivas sementes, demonstrando a conformidade do ensaio. Em decorrência desse fato, o ensaio com água a $50^{\circ} \mathrm{C}$ obteve apenas 18 valores de atividade resultantes de vazamento das sementes. A FIG. 28 mostra as imagens das sementes de $n^{\circ} 47$ (a) e de $n^{\circ} 60$ (b).

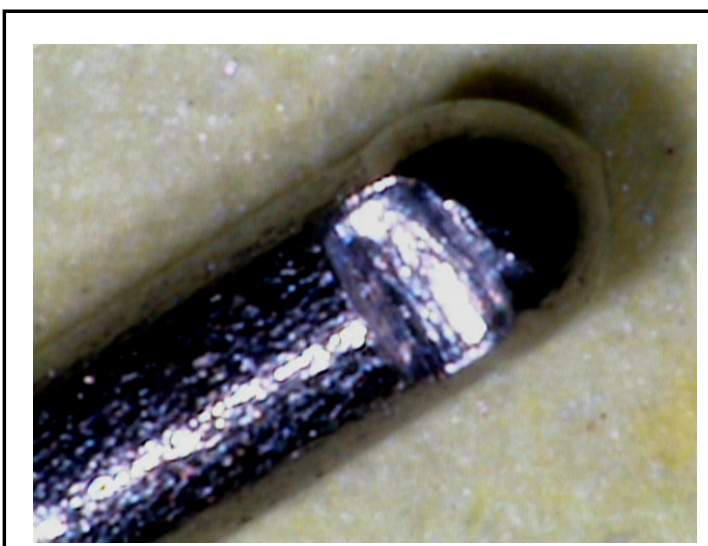

(a)

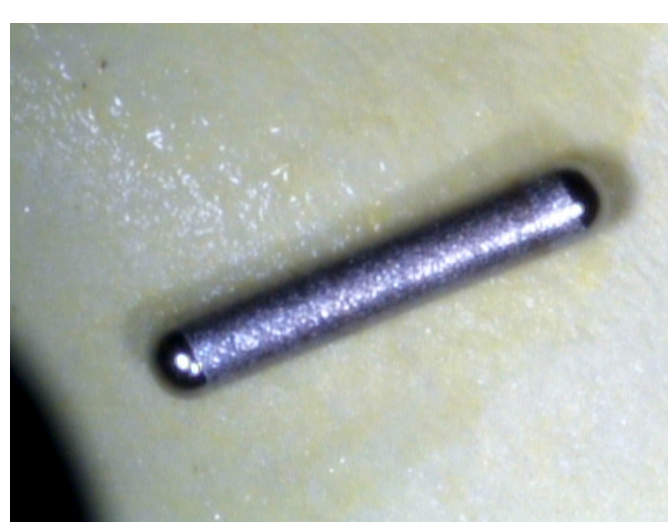

(b)

FIGURA 28: Imagens das sementes $n^{\circ} 47$ (a) e $n^{\circ} 60$ (b).

- Resultados do ensaio de imersão em água destilada com temperatura de 70 ㅇ

$\mathrm{Na}$ TAB. 21 são mostrados os valores de atividade obtidos com 0 ensaio de imersão em água destilada à temperatura de $70^{\circ} \mathrm{C}$ por 30 minutos, com aplicação simultânea de ultra-som. O ensaio foi realizado com as sementes de no 61 a 80. 
TABELA 21: Resultados dos ensaios de estanqueidade à temperatura de $70^{\circ} \mathrm{C}$.

\begin{tabular}{cccccccc}
\hline $\begin{array}{c}\text { Semente } \\
\mathbf{n} \mathbf{0}\end{array}$ & $\begin{array}{c}\text { Atividade } \\
\mathbf{( k B q )}\end{array}$ & $\begin{array}{c}\text { Semente } \\
\mathbf{n}^{\mathbf{0}}\end{array}$ & $\begin{array}{c}\text { Atividade } \\
\mathbf{( k B q )}\end{array}$ & $\begin{array}{c}\text { Semente } \\
\mathbf{n} \mathbf{0}\end{array}$ & $\begin{array}{c}\text { Atividade } \\
\mathbf{( k B q )}\end{array}$ & $\begin{array}{c}\text { Semente } \\
\mathbf{n}^{\mathbf{0}}\end{array}$ & $\begin{array}{c}\text { Atividade } \\
\mathbf{( k B q )}\end{array}$ \\
$\mathbf{6 1}$ & 581,8 & $\mathbf{6 6}$ & 2475,0 & $\mathbf{7 1}$ & 7925,7 & $\mathbf{7 6}$ & 227,2 \\
$\mathbf{6 2}$ & 247,1 & $\mathbf{6 7}$ & 1978,1 & $\mathbf{7 2}$ & 4053,0 & $\mathbf{7 7}$ & 2358,6 \\
$\mathbf{6 3}$ & 3149,6 & $\mathbf{6 8}$ & 1921,9 & $\mathbf{7 3}$ & 3442,5 & $\mathbf{7 8}$ & 643,3 \\
$\mathbf{6 4}$ & 739,0 & $\mathbf{6 9}$ & 2915,6 & $\mathbf{7 4}$ & 264,6 & $\mathbf{7 9}$ & 529,6 \\
$\mathbf{6 5}$ & 1247,3 & $\mathbf{7 0}$ & 5990,7 & $\mathbf{7 5}$ & 2672,4 & $\mathbf{8 0}$ & 175,8 \\
\hline
\end{tabular}

O valor médio foi de $2053561 \mathrm{~Bq}$ (cerca de 11100 vezes o valor limite de $185 \mathrm{~Bq}$ ) e o valor mínimo foi de $175846 \mathrm{~Bq}$ (cerca de 950 vezes o valor limite de $185 \mathrm{~Bq}$ ). Esses valores demonstram a boa eficácia deste método, que tem como vantagem o período reduzido de imersão (apenas 30 minutos) quando comparado aos outros métodos. A desvantagem desse método é a temperatura elevada do líquido de imersão $\left(70^{\circ} \mathrm{C}\right)$, necessitando de maior potência de aquecimento no banho de imersão e ocasionando evaporação de água no ambiente confinado onde serão executados os ensaios.

\section{- Resultados do ensaio de imersão em água destilada e fervura}

A TAB. 22 apresenta os valores de atividade obtidos nos ensaios de imersão em água destilada com fervura, realizados com as sementes de $n^{\circ} 81$ a 100.

TABELA 22: Resultados dos ensaios de estanqueidade com fervura.

\begin{tabular}{cccccccc}
\hline $\begin{array}{c}\text { Semente } \\
\mathbf{n} \mathbf{0}\end{array}$ & $\begin{array}{c}\text { Atividade } \\
\mathbf{( k B q )}\end{array}$ & $\begin{array}{c}\text { Semente } \\
\mathbf{n} \mathbf{0}\end{array}$ & $\begin{array}{c}\text { Atividade } \\
\mathbf{( k B q )}\end{array}$ & $\begin{array}{c}\text { Semente } \\
\mathbf{n}-\end{array}$ & $\begin{array}{c}\text { Atividade } \\
(\mathbf{k B q})\end{array}$ & $\begin{array}{c}\text { Semente } \\
\mathbf{n} \mathbf{0}\end{array}$ & $\begin{array}{c}\text { Atividade } \\
(\mathbf{k B q})\end{array}$ \\
$\mathbf{8 1}$ & 68,0 & $\mathbf{8 6}$ & 61,0 & $\mathbf{9 1}$ & 47,7 & $\mathbf{9 6}$ & 49,8 \\
$\mathbf{8 2}$ & 110,8 & $\mathbf{8 7}$ & 52,2 & $\mathbf{9 2}$ & 74,4 & $\mathbf{9 7}$ & 147,8 \\
$\mathbf{8 3}$ & 63,8 & $\mathbf{8 8}$ & 103,3 & $\mathbf{9 3}$ & 139,1 & $\mathbf{9 8}$ & 76,8 \\
$\mathbf{8 4}$ & 76,7 & $\mathbf{8 9}$ & 69,3 & $\mathbf{9 4}$ & 72,8 & $\mathbf{9 9}$ & 85,8 \\
$\mathbf{8 5}$ & 95,2 & $\mathbf{9 0}$ & 107,7 & $\mathbf{9 5}$ & 64,2 & $\mathbf{1 0 0}$ & 101,4 \\
\hline
\end{tabular}

O valor médio obtido com esse método foi de $83392 \mathrm{~Bq}$, equivalente a cerca de 450 vezes o valor limite de $185 \mathrm{~Bq}$. O valor mínimo foi de $47658 \mathrm{~Bq}$, equivalente a cerca de 257 vezes o valor limite.

A eficácia de detecção de vazamento foi inferior aos métodos que utilizam temperaturas inferiores no líquido de imersão. Além disso, o método com fervura necessita utensílios e equipamentos adicionais e requer também cuidados especiais para sua execução no ambiente confinado. O roteiro de execução foi o 
de maior complexidade e exigiu maior habilidade e cuidado do executante. Neste estudo, o método com fervura apresentou mais dificuldades do que vantagens.

A TAB. 23 apresenta os valores médios e mínimos para cada um dos métodos ensaiados. A FIG. 29 mostra graficamente os valores médios e a FIG. 30 mostra graficamente os valores mínimos.

TABELA 23: Valor médio e mínimo de atividade para cada método ensaiado.

\begin{tabular}{|c|c|c|c|c|c|}
\hline & $\begin{array}{c}\text { Ensaio com } \\
\text { líquido } \\
\text { cintilador }\end{array}$ & $\begin{array}{c}\text { Ensaio com } \\
\text { água a } 20^{\circ} \mathrm{C}\end{array}$ & $\begin{array}{c}\text { Ensaio com } \\
\text { água a } 50^{\circ} \mathrm{C}\end{array}$ & $\begin{array}{c}\text { Ensaio com } \\
\text { água a } 70^{\circ} \mathrm{C}\end{array}$ & $\begin{array}{c}\text { Ensaio com } \\
\text { água } \\
\text { fervente }\end{array}$ \\
\hline $\begin{array}{c}\text { Valor médio } \\
\text { (Bq) }\end{array}$ & $\mathbf{5 7 5 , 3 0}$ & $\mathbf{2 0 7 6 7 0 0}$ & $\mathbf{1 1 1 6 4 8 2}$ & $\mathbf{2 0 5 3 5 6 1}$ & $\mathbf{8 3 3 9 2}$ \\
\hline $\begin{array}{c}\text { Valor mínimo } \\
\text { (Bq) }\end{array}$ & $\mathbf{1 6 4 , 8 5}$ & $\mathbf{5 1 4 3 2 5}$ & $\mathbf{7 1 9 8 2}$ & $\mathbf{1 7 5 8 4 6}$ & $\mathbf{4 7 6 5 8}$ \\
\hline
\end{tabular}

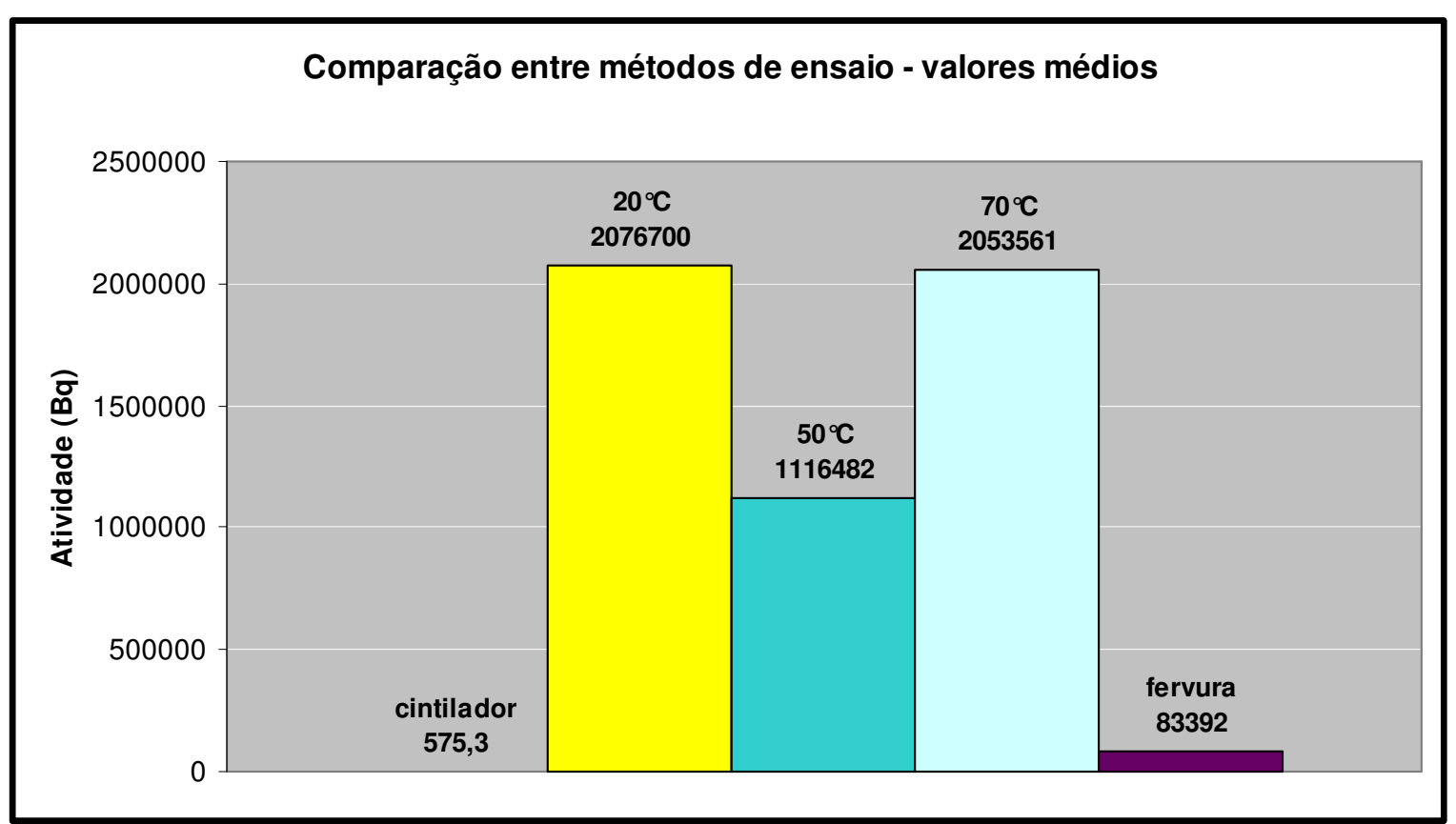

FIGURA 29: Valores médios de atividade para cada método utilizado. 


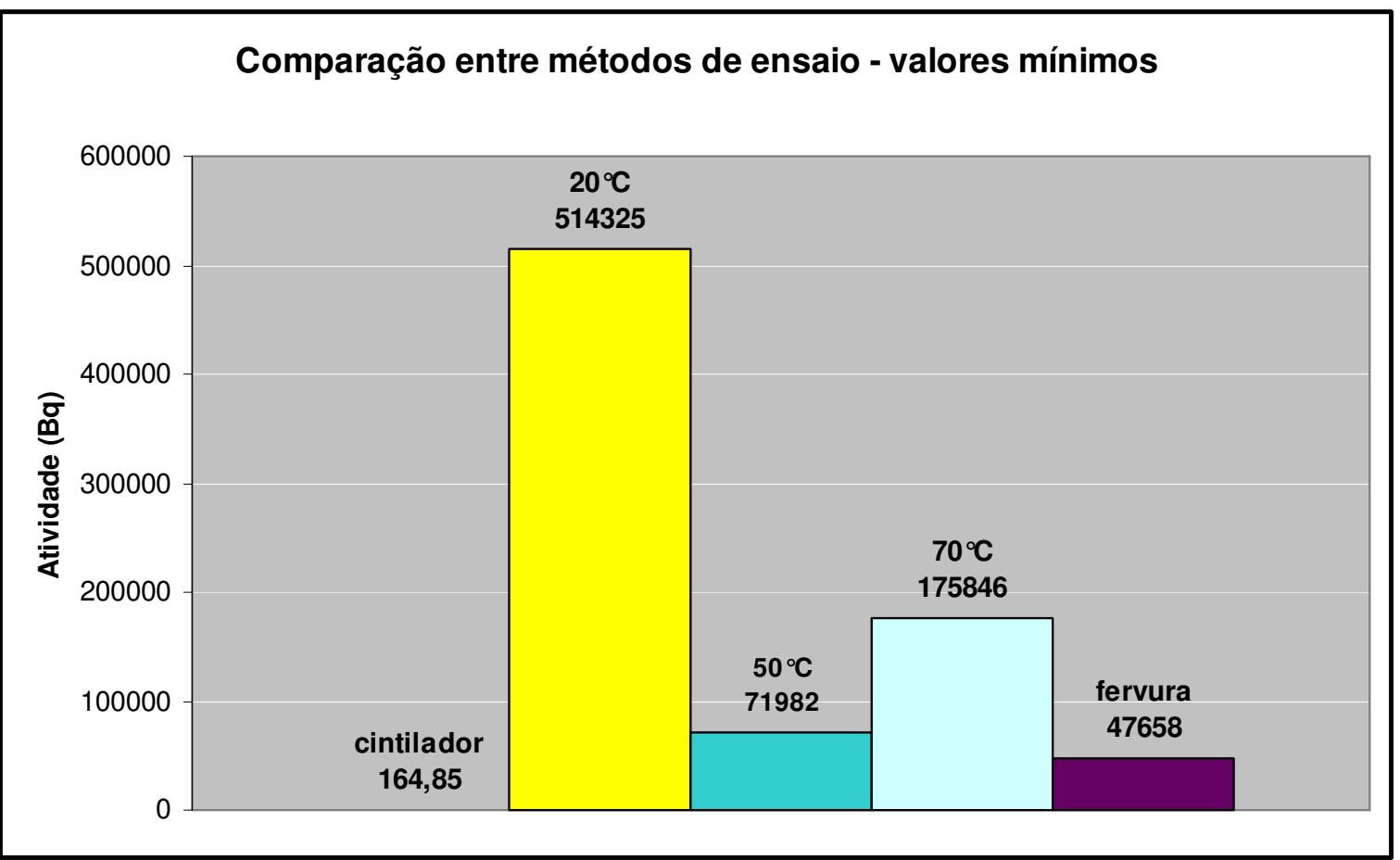

FIGURA 30: Valores mínimos de atividade para cada método utilizado.

\subsection{Fluxograma de processo do ensaio de estanqueidade}

Foram analisados os requisitos da norma ISO $9978^{20}$ e realizados os ensaios de estanqueidade por imersão, segundo os roteiros recomendados. Também foram feitas as simulações de todo o processo de controle de qualidade, desde a recepção das sementes seladas até sua disponibilização. De acordo com os resultados obtidos e as informações coletadas, gerou-se um fluxograma básico do processo, contemplando suas principais fases. Na fase inicial as sementes serão agrupadas em lotes de 30 sementes por tubo. $O$ ensaio de estanqueidade será realizado no lote inteiro e esse será aprovado ou reprovado. Em caso de reprovação, o lote será dividido e cada semente será ensaiada individualmente, sendo aprovada ou reprovada. A FIG. 31 mostra o desenho do fluxograma. 


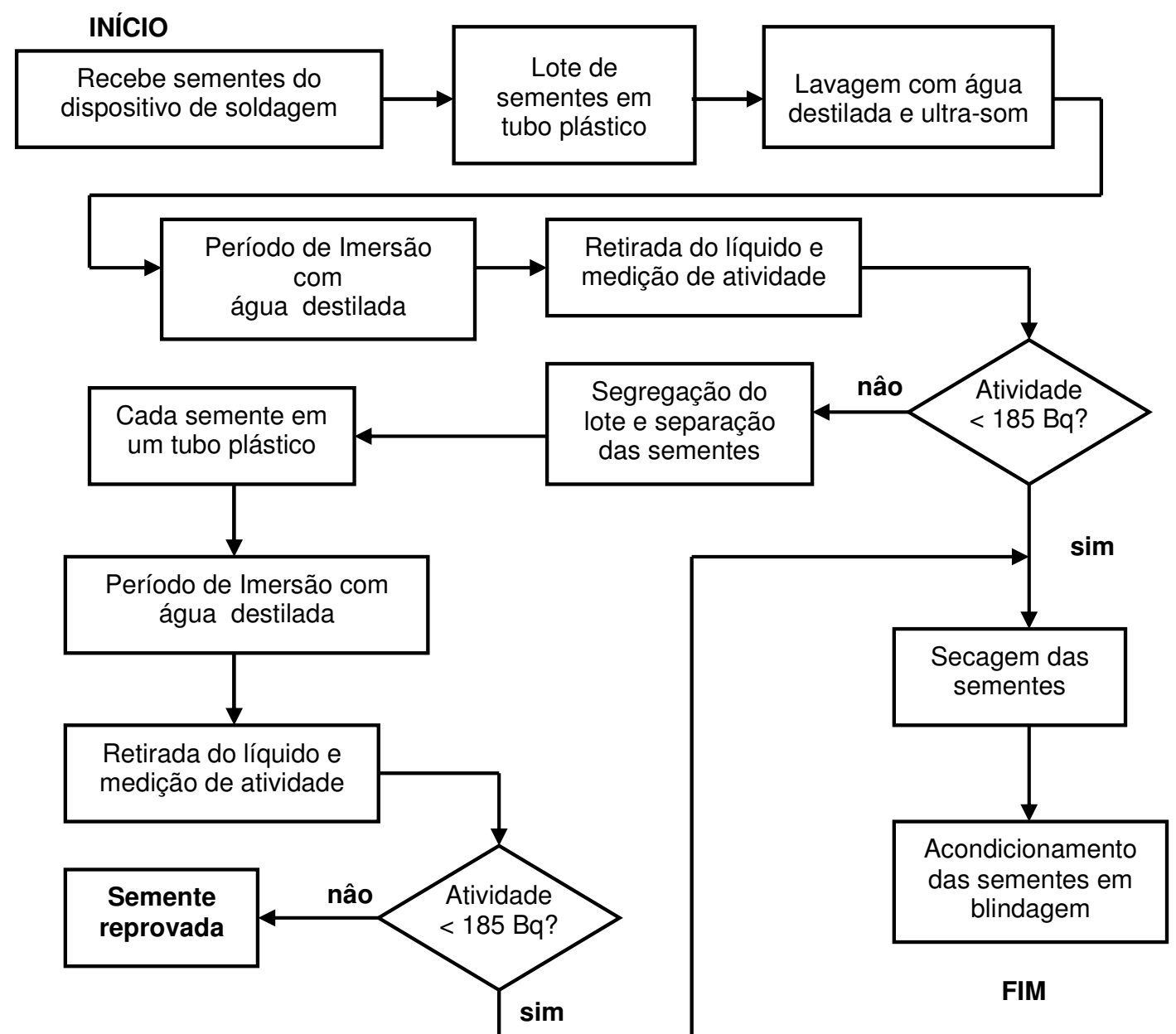

FIGURA 31: Fluxograma de processo dos ensaios de estanqueidade 


\section{CONCLUSÕES}

Os diversos experimentos e desenvolvimentos realizados permitem estabelecer condições e parâmetros, a serem adotados na produção das sementes:

1. Para a limpeza inicial de todas as sementes, após processo de soldagem, serão realizadas as seguintes etapas:

- Realizar cinco ciclos de lavagem com água destilada, com duração de 10 minutos cada ciclo.

- Aplicação de ultra-som durante o período de lavagem.

2. Na automação dos ensaios de estanqueidade, as tubulações de transporte de líquidos utilizarão mangueiras de PTFE (Teflon) com diâmetro interno de 1 $\mathrm{mm}$. As condições para descontaminação as tubulações são:

- Sucção através de bomba de vácuo com sistema de retenção e filtração de partículas, prevenindo contaminação ambiental. A alta velocidade de deslocamento do fluído dentro dessa tubulação arrasta com maior eficiência o material radioativo, facilitando a descontaminação. $O$ fluxo recomendado é de $45 \mathrm{ml} /$ minuto utilizando-se mangueira com diâmetro interno de $1 \mathrm{~mm}$.

- O volume de água destilada utilizado para descontaminação da tubulação deverá ser de no mínimo $75 \mathrm{ml}$.

3. As sementes de iodo -125 , após a etapa de soldagem, serão enviadas à célula de controle de qualidade e agrupadas em lotes de 30 sementes para as etapas posteriores de limpeza superficial e ensaio de estanqueidade. Caso seja detectado vazamento, todo o lote será segregado e as sementes serão ensaiadas separadamente para identificação da unidade defeituosa.

4. Na etapa de secagem das sementes será feita uma adaptação de um aparelho aspirador de pó para proporcionar o fluxo de ar necessário. O tempo de secagem será de 60 segundos no mínimo. 
5. A disposição dos equipamentos no interior da caixa de confinamento deverá se orientar pelo desenho de lay-out estabelecido durante os estudos.

6. O projeto definitivo de automação do processo de ensaios de estanqueidade terá como base os modelos de dispositivos e o fluxograma de processo desenvolvido durante os estudos.

7. Os ensaios mais indicados para serem realizados durante a produção das sementes são:

- ensaio com água destilada a temperatura ambiente $\left(20^{\circ} \mathrm{C} \pm 5^{\circ} \mathrm{C}\right) \mathrm{com}$ imersão por 24 horas e aplicação simultânea de ultra-som por 10 minutos;

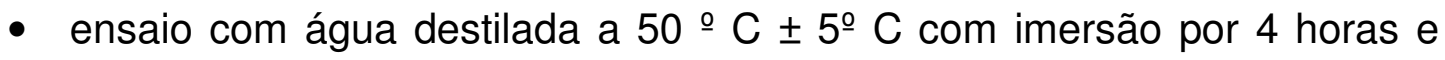
aplicação simultânea de ultra-som por 30 minutos;

- ensaio com água destilada a $70^{\circ} \mathrm{C} \pm 5^{\circ} \mathrm{C}$ com imersão por 30 minutos e aplicação simultânea de ultra-som durante todo o período de imersão.

A norma ISO $9978^{20}$ prevê a aplicação de ultra-som no ensaio por imersão a $70^{\circ} \mathrm{C}$, mas não nos demais métodos. Em consequência dos bons resultados obtidos, a aplicação de ultra-som foi incluída nos ensaios a $20^{\circ} \mathrm{C}$ (aplicação durante 10 minutos) e a $50{ }^{\circ} \mathrm{C}$ (aplicação durante 30 minutos), sendo utilizado em todos os experimentos posteriores. Essa modificação nos ensaios recomendados excede as exigências da norma ISO $9978^{20}$. A aplicação de ultrasom já foi prevista na etapa inicial dos ensaios (limpeza superficial das fontes após a operação de selagem da cápsula de titânio) sendo necessária a instalação de uma lavadora ultrasônica. Portanto será utilizado o mesmo equipamento na fase de imersão das sementes, sem a necessidade de se acrescentar outro recurso ao processo.

O tempo é um fator importante durante o processo de produção das sementes. A determinação do método mais indicado para utilização no processo produtivo deve levar em conta além da sensibilidade de detecção, o tempo disponível para sua realização. Em um cenário projetado onde diariamente ocorram produções de sementes, os métodos de ensaio indicados seriam os que utilizam água a $70^{\circ} \mathrm{C}$ (preferivelmente) e água a $50^{\circ} \mathrm{C}$, devido aos curtos períodos de imersão necessários. Caso ocorram folgas nas atividades de produção, o método com água a $20^{\circ} \mathrm{C}$ seria o mais indicado, tanto pelo baixo valor de temperatura, o que dispensa o uso de sistema de aquecimento, como pela alta 
sensibilidade demonstrada nos ensaios. Assim, a escolha definitiva deverá ser feita quando for iniciada a produção experimental das sementes. 


\section{REFERÊNCIAS BIBLIOGRÁFICAS}

1 - RICE, D. P.; HODGSTON, T.A. Incidentes sociales et economiques du cancer aux États-Unids d"Amerique. World Healt Stat., v. 33, n. 1, p. 56-100, 1980.

2 - ISSELBACHER, k. J. ; BRAUNWALD, E. ; WILSON, J. ; MARTIN, J. ; FAUCI, A. ; KASPER, D. Harison/Medicina Interna. Volume II. 13ª edição. Mc GrawHill. 1995.

3 - ORGANIZAÇÃO MUNDIAL DE SAÚDE (OMS) apud MINISTÉRIO DA SAÚDE. INSTITUTO NACIONAL DE CÂNCER. Estimativa da incidência e mortalidade por câncer no Brasil 1999. Rio de Janeiro, 1999.

4 - BRASIL. MINISTÉRIO DA SAÚDE. INSTITUTO NACCIONAL DE CÂNCER. Estimativa 2008: Incidência de câncer no Brasil. Rio de Janeiro: 2007. Disponível em <www.inca.gov.br>. Acesso em 30/10/2008.

5 - SPENCE, A. P. Anatomia humana básica. São Paulo. Manole. 1991.

6 - JUNQUEIRA, L. C.; CARNEIRO, J. Histologia básica. 7ª edição. Guanabara Koogan. 1990.

7 - SROUGI, M. A próstata como ela é. Folha de São Paulo, São Paulo, 03 de nov. 2002. Caderno Cotidiano, p. 8.

8 - BRASIL. MINISTÉRIO DA SAÚDE. INSTITUTO NACIONAL DE CÂNCER. Câncer de próstata. Disponível em < www.inca.gov.br >. Acesso em 03/11/2006.

9 - AMERICAN CANCER SOCIETY, NCCS-ACS. Prostate cancer treatment. Guidelines for patients. 1999.

10 - OKUNO, E.; CALDAS, I. L. ; CHOW, C. Física para ciências biológicas e biomédicas. São Paulo: Harper \& Row do Brasil. 1982. 
11 - AMERICAN UROLOGICAL ASSOCIATION PROSTATE CANCER. Clinical Guidelines Panel "The management of localized prostate cancer - a patient's guide". USA: 1998.

12 - ROSTELATO, M. E. C. M. Estudo e desenvolvimento de uma metodologia para confecção de sementes de iodo-125 para aplicação em braquiterapia. 2005. Tese (Doutorado). Instituto de Pesquisas Energéticas e Nucleares. São Paulo.

13 - Radioisotope production and quality control. Technical Reports Series $\mathrm{n}^{\circ}$ 128. International Atomic Energy Agency. Vienna, 1971.

14 - LEGRAND, J.; PEROLAT, J.; LAGOUTINE, F.; GALLIC, Y. Table de radionucléides Commissariat à l'Energie Atomique Bureal National de Métrologie. França, 1975.

15 - Update of X ray and gamma ray decay data standards for detector calibration and other application. Vienna: International Atomic Energy Agency. 2007. Disponível em: <http://www.iaea.com>. Acesso em $18 / 3 / 2009$.

16 - FEHER, A. Desenvolvimento de procedimento utilizando processo de soldagem plasma para confecção de sementes de ${ }^{125}$ I. 2006. Dissertação (Mestrado) - Instituto de Pesquisas Energéticas e Nucleares, São Paulo.

17 - AMERSHAM HEALTHCARE. I-125 RAPID Strand. USA: 2000. N.7000. (catálogo comercial).

18 - AMERSHAM HEALTHCARE. I-125 Seeds. USA: 2000. N. 6711. (catálogo comercial).

19 - NYCOMED AMERSHAN PLC. Instructions for the use of idine-125 seeds for medical brachitherapy treatments. December 1999.

20 - INTERNATIONAL STANDARD ORGANIZATION. Radiation protection sealed radioactive sources - leakage test methods. Feb. 15. 1992. (ISO 9978).

21 - INTERNATIONAL STANDARD ORGANIZATION. Radiation protection sealed radioactive sources - General requirements and classification. Feb. 15. 1992. (ISO 2919).

22 - ASSOCIAÇÃO BRASILEIRA DE CÂNCER - Braquiterapia. Disponível em: $<$ http://www.abcancer.org.br/materia.asp?id=168>. acesso em 08/03/2006. 
23 - FERNANDES, M. A. R.; Utilização de moldes radioativos especiais de folha de Ouro-198 para braquiterapia em tumores de pele. 2000. Tese (Doutorado) - Instituto de Pesquisas Energéticas e Nucleares. São Paulo.

24 - HAZLETON - NUCLEAR SCIENCE CORPORATION. Donald C. Lawrence. Therapeutic metal seed containing within a radioactive isotope disposed on a carrier and method of manufacture. US Pat. n. 3,351,049, nov. 7, 1967.

25 - WHITMORE, W. F.; HILLARIS, B.; GRABSTALD, H. Retropubic implantation of iodine-125 in the treatment of prostatic cancer. J. Urol., v. 108, p. 918, 1972.

$26-\mathrm{HOLM}, \mathrm{H}$. H. The history of intersticial brachytherapy of prostatic cancer. Semin. Surg. Oncol., v. 13, n. 6, p. 432-437, 1997.

27 - REVISTA SOCIEDADES BRASILEIRAS DE CANCER - Braquiterapia de câncer de próstata - revisão e experiência inicial. Disponível em: $<$ http://www.rsbcancer.com.br/rsbc/8artigo2.asp?nrev=N8>. Acesso em 26/10/2006.

28 - FAN, H.; JIN, X.; BAI, H. Preparation of ${ }^{125}$ I seed sources for implantation therapy of prostate cancer. Final report of a coordinated research project. IAEA -TECDOC-1512. 2001-2005.

29 - SON, K.J.; LEE, J.S.; PARK, U.J.; HONG, S.B.; SEO, K.S.; HAN, H.S. Development of miniature radiation sources for medical and nondestructive test applications. Final report of a coordinated research project. IAEA -TECDOC-1512. 2001-2005.

30 - BENITES, M.; MIRANDA, J.; CONDOR, R.; CAVERO, L.; MARTÍNEZ, R. Production of ${ }^{125}$ I for brachytherapy uses. Final report of a coordinated research project. IAEA -TECDOC-1512. 2001-2005.

31 - CIESZYKOWSKA, I.; PIASECKI, A.; MIELCARSKI, M. Development of sealed sources for use in brachytherapy. Final report of a coordinated research project. IAEA -TECDOC-1512. 2001-2005.

32 - DASH, A.; SAXENA, S.K.; MANOLKAR, R.B.; SHANTA, A.; MAJALI, M.A.; VENKATESH, M. Development of miniature ${ }^{125}$ I sources for the treatment of eye and prostate cancers. Final report of a coordinated research project. IAEA -TECDOC-1512. 2001-2005. 
33 - SAXENA, S.K.; SHANTA, A.; RAJURKAR, N.S.; MAJALI, M.A. Studies on the production and quality assurance of miniature ${ }^{125}$ | radioactive sources suitable for treatment of ocular and prostate cancer. Appl. Radiat Isot , v. 64, p. 441-447.

34 - HARPER, C. A.; PETRIE, E. M.; Plastics materials and processes: $\boldsymbol{A}$ concise encyclopedia. Willey - Interscience. 2003.

35 - Guia para a expressão da incerteza de medição. Segunda Edição Brasileira do Guide to the Expression of Uncertainty in Measurement. Edição revisada. Agosto de 1998. ABNT, INMETRO. 